\author{
UNIVERSIDADE DE SÃO PAULO \\ FACULDADE DE CIÊNCIAS FARMACÊUTICAS \\ CURSO DE PÓS-GRADUAÇÃO EM CIÊNCIA DOS ALIMENTOS \\ ÁREA DE BROMATOLOGIA
}

\title{
Aeromonas DO GRUPO A. hydrophila EM AMOSTRAS DE HORTALIÇAS COMERCIALIZADAS NA CIDADE DE SÃO PAULO
}

\author{
SUSANA MARTA ISAY SAAD
}

Dissertação para obtenção do grau de

MESTRE

Orientador:

Prof. Dr. Sebastiāo Timo laria

SÃO PAULO

1993 
Ao meul marido Roberto
pelo carinho
e compreensaro

aos meus filhos Sandra e Fabio 
Este trabalio foi desenvolvido no Laboratorio de Microbiologia de Alimentos do Departamento de Microbiologia do Instituto de Ciencias Biomedicas da Universidade de Sสo Faulo, sob apoio financeiro da Fundaça de Amparo à Fesquisa do Estado de Săo Paulo (FAPESP), como parte de um projeto de pesquisa envolvendo as bacterias do genero Aeromonas e com auxilio de uma Bolsa de Estudos concedida pela Coordenaça de Aperfeiçoamento de Fessoal de Nivel Superior (CAPES). 


\section{AGRADECIMENTOS}

- Ao Frof. Dr. Sebastiào Timo Iaria, pela orientaçăo, dedicaça e os momentos construtivos de convivencia

- A Prof. Dra. Sirdeia Maura Ferrone furlanetto, do Departamento de Microbiologia do Instituto de Ciencias Biomedicas da USF, pelo apoio e amizade

- A Frofa. Dra. Bernadette Dora Gombossy de Melo Franco, do Departamento de Alimentos e Nutriça Experimental da Faculdade de Ciencias Farmaceuticas da USF, pelo estimulo e amizade

- Ao Prof. Dr. Omar Miguel, do Departamento de Prática de Saúde Pública da Faculdade de Saúde fública da USF, pela anklise estatistica efetuada

- A Frofa. Dra. Maria Lúcia Cerqueira Campos, do Departamento de Microbiologia do Instituto de Ciencias Biomedicas da USF, e à Profa. Dra. Mariza Landgraf, do Departamento de Alimentos e Nutricazo Experimental da Faculdade de Ciencias Farmaceuticas da USP, pelo apoio.

- A Frofa. Dra. Marilene De Vuono Camargo Fenteado, ao Frof. Dr. Jorge Mancini Filho e a todos os docentes, funcionarios e colegas do Departamento de Alimentos e Nutriço Experimental da Faculdade de Ciencias Farmaceuticas da USF, pela oportunidade e o prazer de fazer o curso de posgraduaça

- Ao Frof. Dr. Flavio Alterthum, a Frofa. Dra. Heloiza R. Barbosa, à técnica Rosa Carvalho Gamba, a pos-graduanda, Fabiana Cristina Fimenta $e$ a todos os docentes, funcionarios e colegas do Departamento de Microbiologia do Instituto de Ciencias Biomédicas da USF, por inúmeras contribuiçôs dadas durante a realizaçăo deste trabalho 
- A Coordenaça de Aperfeicoamento de Fessoal de Nivel Superior (CAFES) pela Bolsa de Estudos concedida $e$ a Fundacão de Amparo a Fesquisa do Estado de São Faulo (FAF'ESF) pelo financiamento deste trabalho

- As bibliotecarias Carmelina de Facio, Isabel Tereza Lopes de Andrade, Maria do Socorro B. Rocha, Marily Antonelli Graeber, Fita de Cassia Ortega Borges e Tereza Cristina Souto Maior, do Instituto de Ciencias Biomedicas da USF; E Moema Rodrigues dos Santos, do Conjunto das Químicas da USF por contribuiçóes na busca e na enumeraçăo correta das referencias bibliograficas

- A Frofa. Dra. Maria Regina Fernandes de Toledo, do Departamento de Microbiologia e Imunologia da Escola Paulista de Medicina, pelo fornecimento de cepas de A. hydrophila, A. caviae e A. sobria

- A Maria Jose Silveira, do Laboratorio de Analises Clinicas Fleury, pelo fornecimento de uma cepa hemolitica de Staphylococcus aureus para o CAMP-test

- A D. Norma F. Timo Iaria e familia pela consideraçăo 


\title{
Aeromonas DO GRUPO A. hydrophila EM AMOSTRAS DE HORTALICAS COMERCIALIZADAS NA CIDADE DE SAO PAULO
}

\author{
Comissão Julgadora
}

Dissertaça para obtença do grau de Mestre

Presidente

10 Examinador

20 Examinador

Saro Paulo, de de 1993 
SUMARID

página

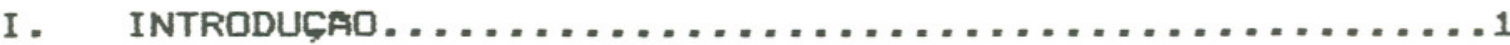

1. Caracteristicas gerais das

Aeromonas do grupo $A$, hydrophila ..............

2. Ocorrencia de Aeromonas do grupo

A. hydrophila em águas e alimentos............

3. Fatogenicidade das Aeromonas

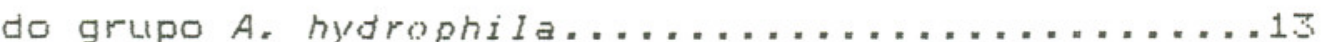

4. Aeromonas do grupo A. hydrophila

como causadoras de gastrenterite............16

5. Fatores de virulencia das

Aeromonas do grupo $A$, hydrophila............23

6. Aeromonas do grupo A. hydrophila

e a segurança de alimentos..................29

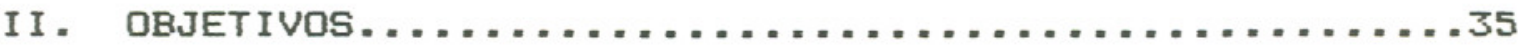

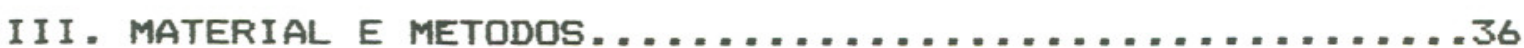

1. Colneita das amostras de

hortaliças para analise...................6

2. Freparo das amostras e de

suas diluiçes..........................36 
página

3. Contagem e teste de presença/ausencia de Aeromonas do grupo $A$. hydrophila...........

3.1 Semeadura inicial das amostras.............37

3.2 Contagem e isolamento de colonias suspeitas..................

3.3 Identificạ̧o das cepas isoladas..........39 3.3.1 Identificaçăo presuntiva...........39 S.3.2 Identificaço definitiva............40

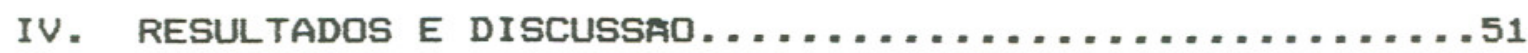

v. ConCLUSOES..............................

VI. REFERENCIAS BIBLIOGRAFICAS...................

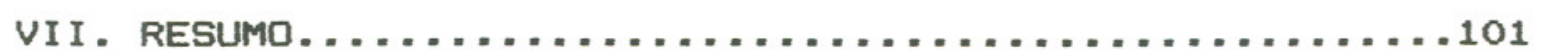

VIII.SUMMARY...................................

IX. ANEXO - Preparo dos meios de cultura,

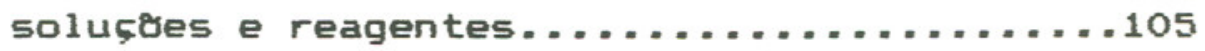




\section{INDICE DE FIGURAS, GRAFICOS E TABELAS}

Figura 1 Fluxograma de isolamento $e$

página identificacăo presuntiva de Aeromonas do grupo $A$. hydrophila a partir de hortaliças............49

Tabela 1 Frovas bioquimicas e microscopicas Lutilizadas na identificaça das cepas isoladas de amostras de hortalicas comercializadas em Să Fialo e resultados esperados para diferentes especies de Aeromonas.................50

Tabela 2 Fiesultados do teste presenca/ausencia e da contagem de Aeromonas do grupo A. hydrophila e especies isoladas, em amostras de hortaliças comercializadas na cidade de să Faulo................71

Tabela 3 Fiesultados do teste presenca/ausencia e da contagem de Aeromonas do grupo A. hydrophila e especies isoladas, em amostras de alface analisadas......................................74

Tabela 4 Fiesultados do teste presença/ausencia e da contagem de Aeromonas do grupo $A$. hydrophila e especies isoladas, em amostras de agriăo

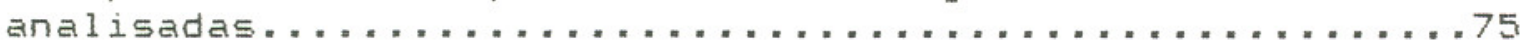

Tabela 5 Fesultados do teste presença/ausencia e da contagem de Aeromonas do grupo A. hydrophila e especies isoladas, em amostras de escarola

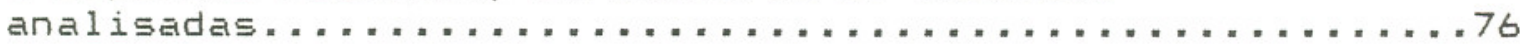

Tabela 6 Variáveis estatisticas das contagens de Aeromonas spp. para as diferentes hortalicas analisadas, em LIFC/g............................. . . . .

Tabela 7 Distribuicăo das amostras de diferentes hortalicas e respectivos percentuais segundo a

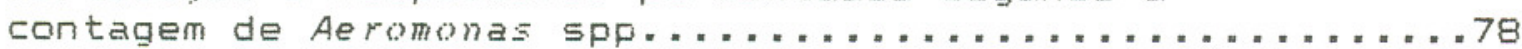

Grafico 1 Distribuiçă dos percentuais de amostras de diferentes hortalicas segundo a contagem de Aeromonas spp. por grama...............79

Tabela 8 Fositividade absoluta e relativa das amostras de hortalicas analisadas frente as duas metodologias de isolamento de Aeromonas spp.

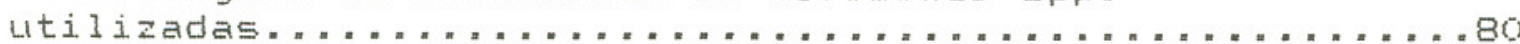


Tabela 9 Cepas isoladas e confirmadas como

pagina Aeromonas spp. e respectiva percentagem para cada 10 amostras e para o total de amostras de

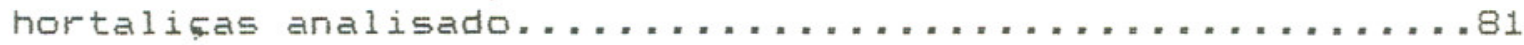

Tabela 10 Número e percentagem das amostras de hortalicas positivas para Aeromonas spp. e para as suas diferentes espécies isoladas, distribuldas segundo os tipos de hortalicas analisadas.............

Tabela 11 Fositividade nos testes bioquimicos

e microscopicos utilizados na identificaça das

4 cepas de $A$. hydrophila e 138 de $A$. caviae

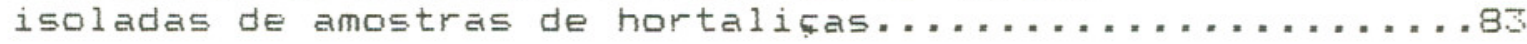




\section{INTRODUCFAO}

\section{Caracteristicas gerais das Aerononas do grupo}

\section{A. hydrophila}

As bacterias pertencentes ao genero Aeromonas tem sido alvo de reclassificaça por parte de diversos pesquisadores, na tentativa de elucidar a posiço desses microrganismos e sua relaça com os de outros generos com caracteristicas similares (JOSEFH et a1., 1987). Segundo o Manual Bergey (FOFOFF, 1984), Elas să classificadas na familia Vibrionaceae, descrita por BAUMANN \& SCHURERT (1984). No entanto, CoLWELL et al. (1986), baseados em estudos sobre genetica molecular, propuseram a sua inclusão em uma nova familia, Aeromonadaceae.

Esses microrganismos săo divididos, de forma geral, em dois sub-grupos, compreendendo um deles as Aeromonas moveis, incluindo as A, hydrophila, A. caviae e A. sobria, E o outro, as imoveis, constituido pela $A$, salmonicida, subespecies salmonicida, achromogenes $e$ masoucida (FOFOFF: 1984). As tres primeiras especies citadas tem sido denominadas por varios autores como "grupo A. hydrophila" (BUCHANAN \& FALUMBO, 1985). Entretanto, JOSEFH et al. (1988) recomendam a denominaça por especie, a fim de que informaçes emergentes possam ser lutilizadas de uma maneira mais especifica. 
Cada uma das tress especies de Aeromonas moveis abrange mais do que um grupo de hibridizaçăo de DNA. Assim sendo, a A. hydrophila abrange tres grupos de hibridizaça, a A. caviae, dois e a A. sobria, pelo menos dois grupos (POPOFF, 1984). Por outro lado, SAKAZAKI \& SHIMADA (1984) consideram $A$. sobria como sinonimo de $A$. hyorophila, baseados na semelhanca entre os DNA dessas duas especies, observada em uma pesquisa nå publicada, por eles realizada.

Com relaça à divisão das Aeromonas moveis em especies, BARER et al. (1986) sugerem a possibilidade da existencia de um quarto grupo distinto dessas bacterias, a qual poderia constituir uma nova especie ou uma subespecie.

HICKMAN-BRENNER et al. (1987, 1988), por sua vez, sugerem a inclusão de duas espécies adicionais de Aeromonas móveis as já existentes. A primeira dessas especies sugeridas por HICKMAN-BRENNER et al. (1987) e a A. veronii, diferenciada das outras especies de Aeromonas por se revelar positiva na prova de descarboxilaçăo da ornitina e, negativa na da hidrólise da arginina. A segunda dessas especies sugeridas por HICKMAN-BRENNER et al. (1988) e a A. schubertii, caracterizada pela năo utilizaçăo do manitol. Entretanto, HICKMAN-BRENNER et al. (1987) relatam que muitas cepas de referencia e de coleçoes de laboratorio eram altamente relacionadas à A. veronii, apesar de serem lisina e arginina positivas e ornitina negativas. Baseados neste fato, CARNAHAN et al. (1991) afirmam que as cepas de A. sobria de origem clínica devem ser consideradas como uma 
biovariedade de $A$. veronit. Estes pesquisadores propore que essas cepas sejam denominadas $A$. veronii bv. sobria e que as cepas positivas para a descarboxilaça da ornitina sejam denominadas $A$, veronit bv. veronit.

As Aeromonas sao bacilos Gram-negativos, com extremidades arredondadas ou cocbides, podendo se apresentar isoladas, aos pares ou em cadeias curtas. As Aeromonas móveis podem variar, consideravelmente, de forma e tamanho, sendo que algumas cepas se apresentam como bacilos curtos, enquanto outras produzem formas finas ou até filamentosas (FOFOFF, 1984).

Com exceça da $A$. salmonicida, as Aeromonas spp. sao móveis por um único flagelo polar, podendo sob determinadas condiç̧es, como por exemplo em culturas jovens em meios solidos, formar flagelos laterais. Saro facultativamente anaeróbias, produzem oxidạ̧a e fermentạ̧a da glicose, utilizam carboidratos com produçaro de acido ou acido e gás, reduzem nitrato a nitrito e såo produtoras de oxidase e catalase; så resistentes ao agente vibriostatico 0/1292,4-diamino-6,7-disopropilpteridina (FOFOFF, 1984) em testes realizados com discos de papel de filtro impregnados com 10 e 150 ug (WEST \& COLWELL, 1984).

As Aeromonas imoveis multiplicam-se em temperaturas de 5 a $350 \mathrm{C}$, sendo a faixa otima a de 22 a $250 \mathrm{C}$. For outro lado, para as moveis a temperatura otima de crescimento é de $280 \mathrm{C}$, a máxima de 38 a $410 \mathrm{C}$ e algumas cepas podem desenvolver-se a 50C (FOFOFF, 1984). A esse respeito, um 
estudo realizado por fALUMBO et al. (1985b), revelou que cepas de origem clínica de $A$. hydrophila eram, em sua maioria, capazes de crescer a $4-50 \mathrm{C}$ e a $420 \mathrm{C}$.

Assim, é importante salientar que as Aeromonas spp. tem caracteristicas de bacterias psicotroficas, dado que podem multiplicar-se nå só em temperatura ambiente, mas tambem sob refrigeraçăo. Essa constataçă é bastante enfatizada por PALUMBo (1986), o qual destaca a A. hydrophila, assim como Clostridium botulinum tipo E, Yersinia enterocolitica, Escherichia coli enterotoxigenica e Listeria monocytogenes como patógenos que pore em risco a segurança de alimentos mantidos sob refrigeraça.

Essa caracteristica psicrotrofica das Aeromonas spp. pode assumir dimensores ainda maiores, tendo em vista que, segundo BUCHANAN (1984), estimativas sugerem que $13 \%$ dos casos relatados de gastrenterite poderiam ser atribuldos a A. hydrophila. No caso especifico dos Estados Unidos, 35 a $40 \%$ das toxinfeç̧ôs alimentares são consideradas como tendo etiologia desconhecida (BUCHANAN, 1984).

Diversos meios de cultura tem sido utilizados para o isolamento de Aeromonas do grupo A. hydrophila. JosefH et al. (1988) fazem uma revisão, enumerando os diferentes meios de isolamento existentes, bem como os trabalhos onde os mesmos săo descritos. Fesquisadores vem utilizando diversos meios de cultura para o isolamento dessas bacterias a partir de alimentos. O agar amido-ampicilina, elaborado por FALUMBO et al. (1985a) tem sido muito utilizado para este fim 
(CALLISTER \& AGGER, 1987; OKREND et a 1., 1987; STERN et al., 1987; LEITAO \& SILVEIRA, 1991). Outros meios que tem sido utilizados são o agar xilose-desoxicolato-citrato (HUNTER \& BURGE, 1987), 口 agar Mac Conckey manitol-ampicilina ou xilose-ampicilina (OKREND et al., 1987), o agar sangue com ampicilina (OKREND et al., 1987; FRICKEF \& TOMPSETT, 1989), - agar peptona-extrato de carne-glicogenio (OKREND et al.. 1987; ABEYTA et al., 1989), o meio Rimler-Shotts (TERNSTROM \& MOLIN, 1987) e Rimler-Shotts modificado (ABEYTA et al., 1986, 1989), 口 agar verde-brilhante com sais biliares (NISHIKAWA \& KISHI, 1988), o kgar Mac Conckey (FRICKER \& TOMPSETT, 1989; ABEYTA et al., 1989) e o agar Wagatsuma modificado (ABEYTA, 1989). Podem ainda ser empregados os meios denominados para Aeromonas, utilizados por FRICKER \& TOMPSETT (1989), KIROV et al. (1990), IBRAHIM \& Mac RAE (1991) e KROVACEK et al. (1992a).

As Aeromonas móveis podem ser isoladas através da semeadura direta em agar seletivo ou apos enriquecimento. 0 caldo tripticase-soja, o caldo triptona, o caldo Rimler Shotts modificado e a agua peptonada alcalina săo alguns meios de enriquecimento utilizados. Segundo VARNAN \& EVANS (1991), o caldo tripticase-soja adicionado de ampicilina é o mais utilizado, embora muitos pesquisadores prefiram a agua peptonada alcalina, dada a possivel presença de cepas sensiveis à ampicilina. 
2. Ocorrencia de Aeromonas do grupo As hydrophila em aguas e alimentos

ABEYTA Jr. \& WEKELL (1988) relatam que as Aeromonas spp. tem sido isoladas de diversas fontes, principalmente aguas, incluindo aguas de bebida tratadas e nao tratadas. AEEYTA Jr. \& WEKELL (1988) citam estudos que demonstraram que o tratamento à base de cloro, de aguas de abastecimento, eliminavam coliformes e E. Coli, mas năo Aeromonas spp.

Segundo ABEYTA Jr. \& WEKELL (1988), as Aeromonas spp. tambem podem estar presentes em aguas salinas, embora sua presença no mar seja apenas transitoria, penetrando nesse ambiente por meio de rios ou esgotos, onde essas bacterias tem-se demonstrado muito frequentes (MONFORT \& BALEUX, 1990; ARAUJo et al., 1991; POFFE \& OF de BEECK, 1991).

HAZEN et al. (1978), por outro lado, afirmam que, embora a $A$. hyơrophila não seja considerada uma bactéria marinha, seu estudo em aguas de diversos regioes dos Estados Unidos indica que a $A$. hydrophila é encontrada naturalmente em sistemas marinhos, na interface com aguas doces.

BURKE et al. (1984c, 1984d), na Australia, verificaram a existencia de um paralelismo entre $\circ$ isolamento de Aeromonas spp. a partir de fezes de casos clinicos e sua presença na agua de abastecimento, tanto clorada (BURKE et al., 1984c) quanto nå clorada (BURkE et al., 1984d). No entanto, na regiăo onde a água de abastecimento era clorada, havia luma ocorrencia maior de Aeromonas spp. no verao, tanto nas fezes quanto na agua (BURKE et al., 1984c), enquanto que) 
na regiăo onde a agua de abastecimento nåo era clorada, a obtença de isolamento de cepas, tanto de casos clinicos quanto de amostras ambientais, continuava no outono e no inverno (BURKE et al., 1984d).

Assim, BURKE et al. (1984d) sugerem que pode haver uma relaça entre a presença de cloro e a ocorrencia de Aeromonas spp. em epocas diferentes do ano, ao invés de uma relaça entre essa ocorrencia e a temperatura do ambiente.

Em outra pesquisa, BURKE et al. (1984b) verificaram que, embora a distribuiçå de diversas caracteristicas bioquimicas diferiam em cepas de origem clinica e ambiental, muitas das cepas isoladas de aguas tinham propriedades relacionadas à virulencia, identicas as das cepas de origem clinica.

WADSTROM \& LJUNGH (1991) sugerem que a alta resistencia revelada por determinadas cepas de Aeromonas a diversos agentes desinfetantes e a outros compostos químicos e antibioticos, pode ser responsavel pela seleça desse patogeno, tornando-o capaz de crescer em determinados habitats aquosos.

WADSTROM \& LJUNGH (1991) citam um surto de gastrenterite aguda, ocorrido no sul da Suécia em 1990, causado por água de uma fonte contaminada, envolvendo, no minimo, 180 adultos jovens.

KROVACEK et al. (1992b), também na Suecia, isolaram Aeromonas spp. de 23 (85\%) de 27 amostras de aqua potavel 
analisadas, obtidas de tres sistemas de distribuiça municipal diferentes.

No Brasil, NEVES et al. (1990) analisaram 50 amostras de agua doce e salgada, poluidas e nato poluidas, obtendo positividade para Aeromonas spp. de 52\% . For outro 1 ado, ressaltam que nas amostras de aguas não poluidas não detectaram a presença dessas bacterias.

Entretanto, Aeromonas spp. tem sido encontradas em outras fontes, como peixes e moluscos, os quais servem de alimento ao homem (ABEYTA Jr., 1988). Com relaçao aos moluscos, MARTINEZ-MANZANARES et al. (1991), na Espanha, observaram maior presença de $A$. hydrophila durante a primavera, em relaçăo as outras estaçơs do ano.

LEUNG et al. (1992) obtiveram contagem de Aeromonas spp. significativamente mais alta nas visceras de peixes (bagres, peixes-gato) do que na kgua e nos sedimentos de seus tanques de criaçă, salientando o risco que esse fato representa quanto à possivel contaminaçăo cruzada na etapa de evisceraça durante o processamento.

Varios autores em diversos paises tem constatado a presença de Aeromonas spp. em diversos tipos de alimentos de origem animal e vegetal. Assim, nos Estados Unidos, PALUMBO et al. (1985a) detectaram bacterias moveis do genero Aeromonas, particularmente $A$, hydrophila, em peixes e frutos do mar, leite cru, carnes de aves e carnes vermelhas, assim como OKREND et al. (1987) em carnes bovina, suina e de aves. Um estudo realizado pela Food and Drug Administration (FDA, 
1985) citado por ABEYTA Jr. \& WEKELL (1988) revelou a presença de Aeromonas 5pp. em 50\% das amostras de leite cru analisadas. CALLISTER \& AGGER (1987) isolaram A. hydrophila e A. caviae de diversos produtos de origem vegetal, incluindo alface de 4 variedades, salsa, espinafre, chicoria, aipo, escarola, brotos de alfafa, couve e brocolos.

BARNHART et al. (1989), tambem nos Estados Unidos, isolaram A. hyorophila de $98 \%$ das carcassas de aves analisadas de uma linha de processamento e de $92 \%$ das amostras de água de resfriamento. Segundo estes autores, o resfriamento com agua e a lavagem resultaram em uma reduçao significativa do número de $A$. hyorophila nas carcassas, enquanto que o armazenamento por 48 horas sob refrigeraço resultou em um aumento significativo do número dessa bacteria. Nesse estudo, os autores săo de opiniåo de que as cepas isoladas das carcassas podem ter sido de origem intestinal e que a etapa de evisceraça foi a causa provável de contaminaça.

FRICKER \& TOMPSETT (1989), na Inglaterra, isolaram Aeromonas de $286(50,8 \%)$ amostras de um total de 563 analisadas de diversos tipos de alimentos. Com relaçăo à positividade para cada tipo de alimento analisado, 69 $(79,3 \%)$ de um total de 87 amostras de carnes de aves, 17 $(38,6 \%)$ de 44 de carne bovina, $21(32,3 \%)$ de 65 de carne suina, $107(84,2 \%)$ de 127 de visceras, $15(31,9 \%)$ de 47 de peixes, $36(37,5 \%)$ de 96 de carnes cozidas e $21(21,6 \%)$ de 
um total de 97 amostras de saladas pre-preparadas revelaram a presença de Aeromonas spp.

Esses pesquisadores salientam que, embora as visceras cruas e as carnes de aves tenham apresentado maior positividade para Aeromonas spp.s a proporçăo relativamente alta de amostras contaminadas de carnes cozidas e de saladas pré-preparadas leva a crer que esses alimentos podem ser importantes fontes de infecça para o homem, por nă sofrerem tratamento termico posterior. Os autores tambem sugerem que, como existem evidencias crescentes de que algumas cepas de Aeromonas spp. podem causar diarreia em seres humanos, e provável que alimentos não cozidos ou que sofram contaminaçăo cruzada atuem como fontes de infeç̣ă.

HUNTEF \& BURGE (1987), também na Inglaterra, isolaram A. caviae de $3(4,5 \%)$ amostras de sorvete de un total de 64 analisadas. Eles atribuiram o aparecimento dessas bacterias no sorvete possivelmente à sua presença em aguas cloradas.

IBRAHIM \& Mac RAE (1991), na Australia, determinaram a presença de Aeromonas spp. e Listeria spp. em 150 amostras de leite de vaca cru e em um total de 150 amostras de carne, sendo 50 de origem bovina, 50 de cordeiro e 50 de carne suina. Verificaram a presença de Aeromonas 5pp. em $27 \%$ das amostras de leite, em $60 \%$ das de carne bovina, em $58 \%$ das de carne de cordeiro e em $74 \%$ das de carne sulna.

MAJEED et al. (1989), tambem na Australia, estudando carne de cordeiro, analisaram 15 amostras de carne picada, 17 de carne moida, 12 de rim e 10 de figado, obtendo 
positividades para Aeromonas spp. de $53 \%, 65 \%, 67 \%$ e $50 \%$, respectivamente.

HUDSON \& de LACY (1991), na Nova Zelündia, determinaram a presença de Aeromonas móveis em 396 amostras de alimentos, os quais constavam, principalmente, de carnes prontas, alimentos contendo moluscos e peixes, embutidos carneos precozidos, saladas de repolho picado e outras verduras, produtos de confeitaria e alguns alimentos crus, como peixes, moluscos e carnes. Os alimentos que apresentaram maiores positividades para Aeromonas moveis foram os moluscos, carnes de cordeiro prontas (cozidas), peixes, carne suina, embutidos carneos e carnes bovinas prontas, ou seja, de $66 \%, 60 \%, 34 \%, 28 \%, 23 \%$ e $21 \%$, respectivamente.

Em moluscos, esses autores obtiveram positividade para Aeromonas móveis de $58 \%$ e $79 \%$ em 48 amostras de alimentos prontos e 19 a serem cozidos, respectivamente. Em peixes, positividades de $35 \%$ e $33 \%$ em 23 amostras de alimentos prontos e 9 a serem cozidos. Quanto à carne sulna, as positividades obtidas foram de $27 \%$ em b3 amostras de alimentos prontos e $32 \%$ em 19 a serem cozidas. Em outras amostras de alimentos, constituidas de pates, saladas, frangos cozidos, verduras prontas para $\square$ consumo e mortadela, as positividades for am de $14 \%, 10 \%, 8 \%, 7 \%$ e $7 \%$, respectivamente.

KNOCHEL \& JEF'FESEN (1990), na Dinamarca, analisaram alimentos de diversos tipos e origens. Dentre os alimentos crus, verificaram a presença de Aeromonas spp. em $25 \%$ de 40 
amostras de carne moida analisadas, em $60 \%$ de 5 de carne moida na forma de "steak tartare" e em $75 \%$ de 12 amostras de peixes moidos. Com relaçăo aos alimentos processados e/ou submetidos ao aquecimento, eles constataram a presença de Aeromonas spp. em $5 \%$ de 236 amostras de carnes preparadas analisadas, em $5 \%$ de 43 de frutos do mar preparados, em $10 \%$ de 177 de saladas com maionese, em $6 \%$ de 177 de bolos e de sobremesas contendo creme, em $50 \%$ de b de creme batido e em $23 \%$ de 26 amostras de creme na forma de "foam pistols".

Apesar da ocorrencia relativamente baixa em alimentos preparados, KNOCHEL \& JEPPESEN (1990) salientam que em diversas ocasioes foram detectadas contagens maiores que $10^{5}$ UFC/g de Aeromonas spp. produtoras de hemolisina.

KROVACEK et al. (1992a), na Suecia, verificaram a presença de Aeromonas spp. em 10 das 24 amostras de alimentos analisadas $(42 \%)$. Esses autores isolaram Aeromonas spp. de carnes de aves, peixes, carne bovina e sulna e não detectaram a presenca dessas bacterias em amostras de hortalicas e de leite cru.

A maioria das cepas por eles isoladas revelaram-se produtoras de diversos fatores de virulencia, como hemolisina, citotoxina, toxina citotonica e proteases e 2 de 13 cepas produziram enterotoxina, com resposta positiva em alca ligada de coelho.

NISHIKAWA \& KISHI (1988), no Japă, analisaram amostras de alimentos de diversos tipos, de fezes humanas diarreicas e năo diarreicas e de aguas. Observaram a presença de 
Aeromonas spp. em 22 (66,7\%) das 33 amostras de peixes de água salgada coletadas no verão, em $1(7,7 \%)$ das 13 amostras de peixes de agua salgada obtidas no inverno, em $b(100 \%)$ das 6 amostras de peixe de agua doce, em $22(51,2 \%)$ das 43 de hortaliças e em $37(77,1 \%)$ das 48 de produtos de carne.

No Brasil, LEITÁ \& SILVEIRA (1991) isolaram Aeromonas spp. de $77,6 \%$ das amostras de origem marinha e $77,8 \%$ das de origem terrestre. As amostras de origem marinha analisadas foram constituidas de 19 de agua, 5 de moluscos, 19 de crustaceos e 15 de peixes, sendo a positividade para essas bacterias de $63,1 \%, 100 \%, 78,9 \%$ e $86,7 \%$, respectivamente. As amostras de origem terrestre foram compostas de 15 de agua de rios, 15 de hortalicas e 15 de peixes de água doce, sendo a positividade para Aeromonas spp. de $100 \%$, $66,7 \%$ e $66,7 \%$, respectivamente.

\section{Patogenicidade das Aeroponas do grupo A. hydrophila}

Quanto à patogenicidade das bacterias do genero Aeromonas, a A. salmonicida năo é considerada patogenica para o homem, porém é o agente causal da furunculose em peixes, doença esta que aparece, particularmente, em salmbes e trutas (FOFOFF \& LALLIEF, 1984).

As Aeromonas móveis săo bastante conhecidas como agentes patogenos para anfibios (FIGNEY et al., 1978), peixes (SHOTTS et al., 1972; MILLER \& CHAPMAN, 1976), cobras (HEYWOOD, 1968), répteis (MARCUS, 1971; SHOTTS et al., 1972; 
GORDEN et al., 1979), vacas (WOHLEGEMUTH et al., 1972), pássaros (KORBEL \& KOSTERS, 1989) e homem (vON GRAEVENITZ \& MENSCH, 1968; DAVIS et al., 1978; ALTWEGG \& GEISS, 1989; GHENGHESH, 1989).

\begin{abstract}
Embora as primeiras cepas de Aeromonas tenham sido descritas já na última década do século XIX, a A, hydrophila so foi isolada de material humano pela primeira vez em 1937 por Miles e Halnan e sua patogenicidade só foi estabelecida em 1955 por Caselitz, que a denominou Vibrio jamaicensis (von GRAEVENITZ, 1987). Com o passar do tempo, sla importância em termos de patogenicidade foi aumentando, sendo que o número de pesquisas sobre o assunto atingiu um ponto méximo nos últimos dez anos.
\end{abstract}

Von GRAEVENITZ \& MENSCH (1968) e DAVIS et al. (1978) fizeram revisoles bibliograficas e descriçoes de casos que demonstram a patogenicidade das Aeromonas, particularmente da A. hyorophila, em humanos.

\begin{abstract}
Von GRAEVENITZ \& MENSCH (1968) sugerem a existencia de uma relaça direta entre a doenca diarreica e a presença de um número elevado de Aeromonas nas fezes, atribuindo, ainda, a esses microrganismos a capacidade de causar celulite e septicemia, alem de salientarem a necessidade de se verificar o seu papel nas infecços hospitalares.
\end{abstract}

DAVIS et al. (1978) ressaltam a capacidade que as bacterias do genero Aeromonas, especialmente a 
A. hydrophila, possuem, de provocar serias infecçoses no nomem e a maior suceptibilidade de individuos com algum tipo de comprometimento imunologico.

KETOVER et al. (1973), por sua vez, publicaram um estudo sobre o papel da A. hyơrophila nas septicemias nosocomiais. Segundo esses pesquisadores, 9 pacientes recebendo tratamento contra cancer no "Memorial SloanKettering Cancer Center" desenvolveram septicemia causada pela $A$. hydrophila, sendo que 5 apresentavam lesoes na pele, 2 dos quais com lesdes semelhantes às do ectima gangrenoso, normalmente causado pela Pseudomonas aeruginosa.

Em estudos mais recentes, ALTWEGG \& GEISS (1989) e por GHENGHESH (1989) reúnem descriçoes de diversos casos de infecçoses causadas por bacterias do genero Aeromonas.

JIANG et al. (1991), analisando a resposta intestinal secretoria de imunoglobulina $A$ (SIgA) de estudantes americanos em viagem ao México, observaram que 11 de um total de 12 individuos com diarréia por $A$. sobria ou A. hydrophila tinham seu titulo de sigA contra a cepa infectante, no mínimo, quadruplicado.

\footnotetext{
SHILKIN et al. (1968) enumera tres maneiras pelas quais as espécies de Aeromonas podem afetar os seres humanos, ou sejam: "primeira, como uma infecço entérica de variada severidade; segunda, como uma infecço localizada; terceira,
} 
como uma septicemia, a qual e sempre seria e as vezes fata $1 "$.

ALTWEGG \& GEISS (1989) enLimeram infectoges que podem ser causadas por bacterias do genero Aeromonas a saber: "septicemia, meningite, celulite, fasciite necrotizante, ectima gangrenoso, pneumonia, peritonite, conjuntivites ulcera da cornea, endoftalmite, osteomielite, artrite supurativa, miosite, abscesso hepatico, abscesso subfrenico, colecistite elou colangite ascendente, infeção do trato urinario, endocardite, infecţos do ouvido, nariz e garganta, balanite, etc".

4. Aeromonas do grupo A. hydrophila como causadoras de gastrenterite

A afirmaçăo de que bacterias do genero Aeromonas poderiam causar disturbios intestinais foi feita pela primeira vez por CASELITZ (1958) e confirmada por MARTINEZSILVA et al. (1961), apos lim estudo das fezes de 9 recemnascidos acometidos de gastrenterite. Aeromonas spp. foram isoladas de 6 casos, ocorrendo a morte de um bebe, para o qual a cultura de fezes revelou a presenca exclusiva de Aeromonas spp. (BUCHANAN \& FALUMBO, 1985).

No entanto: apenas a partir da decada de 70, um numero substancial de relatos feitos em muitos países, apontando as Aeromonas do grupo A. hydrophila, particularmente a A. hydrophila e a A. sobria, como possiveis causadoras de 
gastrenterite em humanos, surgiu na literatura (SANYAL et al., 1975; WADSTROM et al., 1976; RAHMAN \& WILLOWGHBY, 1980; ECHEVERRIA et al., 1981; CHAMPSAUR et al., 1982; FITARANGSI et al., 1982; BURKE et al., 1983; JANDA et al., 1983). Nesses relatos foram incluidas as especies apontadas como agentes das diarreias infantil e do viajante, assim como aquelas suspeitas de serem causadoras de surtos de gastrenterites de origens alimentar e hidrica.

BUCHANAN \& FALUMBO (1985) realizaram um estudo de revisào bibliografica sobre as Aeromonas spp. como agentes causadores de gastrenterite. Segundo estes pesquisadores, as analises de amostras fecais de individuos com sintomas de gastrenterite confirmam a hipotese de que bacterias do genero Aeromonas sao patogenas entericas significativas e indicam que a $A$. hydrophila e isolada, aproximadamente, na mesma proporçao que outros importantes patogenos entericos como SaImoneIla spp. e Campylobacter jejuni.

GRACEY et al. (1982), na Australia, fizeram um estudo prospectivo, com a duraçăo de 1 ano, em 1.156 crianças com gastrenterite, utilizando como controle o mesmo número de criancas sadias e com sexo e idade equivalentes. Eles isolaram Aeromonas spp. das fezes de $118(10,2 \%)$ das crianças com diarreia e de apenas $7(0,6 \%)$ das do grupo contrale.

GoODWIN et al. (1983) relataram positividade para A. hydrophila enterotoxigenica em fezes de, aproximadamente, 
$10 \%$ de 500 crianças com sintomas diarreicos, enquanto que essa proporça era apenas de $0,4 \%$ em um grupo controle assintomatico. Esses pesquisadores observaram um perfil semelhante em adultos, embora essas diferenças não fossem tao salientes pelo fato da taxa do microrganismo em questao entre os individuos assintomaticos ser maior.

ECHEVERRIA et al. (1983), por sua vez, observaram, em um estudo realizado no perído de um ano, uma forte relaçao entre a ocorrencia de gastrenterite e o isolamento de A. hydrophila das fezes de individuos com diarréia de uma vila da Tailandia e sugeriram que a mosca domestica seria o provavel vetor de transmissão desse microrganismo.

AGGER et al. (1985), em Michigan, nos Estados Unidos, em um estudo realizado num periodo de 18 meses, isolaram A. hydrophila das fezes de $20(1,1 \%)$ dentre 1.797 pacientes com diarreia. For outro lado, das fezes de 533 individuos sadios, usados como controle, năo obtiveram o isolamento dessa bacteria. Embora a diarréa por A. hydrophila $(1,1 \%)$ tenha se revelado com frequencia muito menor que a causada por Campylobacter jejuni $(8,3 \%)$, a sua ocorrencia era apenas um pouco menor que a diarréa por salmonella $5 p p$. (1,6\%).

\footnotetext{
MOYEF (1987) analisou 3.334 amostras de fezes e observou a predominancia do número de isolamentos de Aeromonas spp. em relaça aos demais patogenos pesquisados. Ele isolou 248 cepas de Aeromonas 5pp. de 238 amostras de fezes de 214 individuos com diarréia, sendo que 10 casos
} 
revelaram-se positivos, simultaneamente, a duas especies de Aeromonas.

NISHIKAWA \& KISHI (1988) isolaram Aeromonas spp. de $11,1 \%$ de 262 amostras de fezes diarreicas e de $2,2 \%$ de 9.104 de fezes não diarrécas, sendo que a maioria das cepas foi isolada no verăo. Faralelamente, nå observaram aumento significativo no número de Aeromonas spp. em aguas de rios e águas de torneiras no verão. Ao mesmo tempo, eles observaram altas contagens de Aeromonas spp. em amostras de diversos tipos de alimentos de origem animal e vegetal. Essas observaçoses concomitantes levaram esses pesquisadores a concluir que a infeçă por Aeromonas spp. poderia ser mais de origem alimentar do que aquática.

MORGAN \& WOOD (1988), em uma revisar, enumeram sete estudos realizados em paises diferentes. Em seis deles, foi demonstrada uma associaça estatisticamente significativa entre a diarréia e a presença de Aeromonas spp. nas fezes e - Ĺnico que não revelou nenhuma associaçă foi o de FIGURA et al. (1986), na Italia.

\footnotetext{
KOBAYASHI \& OHNAKA (1989) mostraram que A. hydrophila e A. sobria ocupavam, em 1984, 1985 e 1986, o terceiro lugar como bactérias causadoras de casos esporadicos de diarréia no Japão, cabendo o primeiro lugar ao C. jejuni e C. coli, o segundo à $P$, shigelloides $e$ os quarto, quinto e sexto lugares ao Vibrio cholerae nao 01, V. fiuvialis e V. mimicus, respectivamente. Esses autores referem que o número de pacientes com diarréia por $A$. hydrophila $e A$.
} 
sobria aumentou de $\$ 87$ em 1984 para 653 em 1985 e 799 em 1986.

Com relạ̧ă aos sintomas das gastrenterites por Aeromonas spp., na maioria dos casos observa-se diarréia aquosa, ocorrendo, muitas vezes, dores abdominais, febre e náuseas e outros sintomas adicionais, como vomitos e muco ou sangue nas fezes (JANDA et al., 1983; AGGER et al., 1985; MOYEF, , 1987).

VARNAN \& EVANS (1991) classificam as infeç̣రిes gastrintestinais causadas por Aeromonas spp. em dois tipos distintos, sendo um com sintomatologia semelhante a da colera. Este, que pode constituir $75 \%$ dos casos, é caracterizado pela ocorrencia de diarreia com fezes aquosas e os pacientes apresentando febre baixa ou ausente. Crianças com menos de dois anos podem apresentar vamitos e individuos de qualquer faixa etaria podem se mostrar com dores abdominais e colicas. Quanto ao segundo tipo, trata-se de uma infeção semelhante a disenteria, em que as fezes apresentam-se muco-sanguinolentas, ocorrendo dores abdominais e, raramente, vomitos.

Deve-se salientar que em casos de gastrenterite por Aeromonas spp. podem ocorrer até 20 evacuaçoes diarias, embora o seu número seja muito variavel (MOYEF, 1987). A faixa etaria em que essa infeçăo aparece com maior frequencia e a de crianças com menos de 2 anos de idade (JANDA et al., 1983; AGGER et al., 1985) e a de adultos com 
idade superior a 60 anos, podendo atingir, entretanto, pessoas de todas as faixas etarias (VARNAN \& EVANS, 1991 ).

Com relaça aos periodos de incubaçă, são relatados periodos de, no mínimo, 12 horas (MAJEED et al., 1990) e de 6 a 36 horas (TODD et al., 1989). Quanto à sua durạ̧ăo, as gastrenterites por Aeromonas spp. são consideradas como sendo geralmente autolimitantes (DAVIS et al., 1978; HOLMEEFG \& FAFMEF, 1984). Entretanto, tem sido relatados periodos de durạ̧ăo de 10 dias a 2 semanas (JANDA et al.. 1983), de 3 a mais de 10 dias (AGGER et al., 1985) e de 3 dias a $b$ meses (MOYEF, 1987). Esse último pesquisador observou em casos de gastrenterite, duracăo de 3 dias a 6 meses, com média de 6 semanas, em infeç̧oses por $A$, cariae, de 7 dias a 1 mes, com media de 3 semanas, por A, hydrophila e de 7 dias a 3 semanas, com média de 1 semana, em infeç̧ores por $A$, sobria.

TODD et al. (1989) enumeram varios episódios de gastrenterite atribuidos a $A$, hydrophila. Dentre eles, tres ocorreram na Inglaterra, em 1978, 1984 e 1985, com 3, 1 e 2 casos, respectivamente. O primeiro foi associado ao consumo de ostras, cuja contagem de $A$. hydrophila foi de $2,0 \times 10^{4}$ UFC/g. Os dois outros, associados ao consumo de camarăo cozido, sendo que no episodio de 1984, a contagem dessas bacterias no alimento foi de $5,0 \times 10^{\circ}$ UFC/g. Outro episodio, também associado ao consumo de camarbes cozidos, ocorreu na Escocia, em 1980, com mais de 20 casos. 
AGEONLAHOR et al. (1982), na Nigeria, descrevem um caso de infecça, associado ao consumo de cobras comestiveis que haviam sido congeladas por 3 semanas, cuja contagem de A. hydrophila fai de $100 \mathrm{UFC/g}$.

ABEYTA Jr. et al. (1986) citam o registro pela FDA, de aproximadamente 472 casos de gastrenterite, ocorridos em Louisiana em 1982, provocados pela ingestão de ostras cruas provenientes de duas regibes e sem conclusaro definitiva quanto ao agente etiológico responsável. No entanto, cerca de um ano apos o episodio citado, um outro surto, com 7 casos, envolvendo o consumo de ostras provenientes da mesma região ocorreu em São Fetersburgo, Florida. Tanto as ostras quanto as fezes dos individuos doentes revelaram-se positivas para A. hydrophila. Devido à semelhança de sintomas e à coincidencia quanto a regiăo de proveniencia das ostras envolvidas em ambos os surtos, as ostras referentes ao surto de 1982 foram analisadas, apos terem sido armazenadas por um ano e meio a $-720 \mathrm{C}$. Destas ostras foram isoladas cepas potencialmente enteropatogenicas de A. hydrophila (ABEYTA Jr., 1986).

KOEAYASHI \& OHNAKA (1989) citam dois surtos de gastrenterite por A. hydrophila ocorridos no Japă, sendo que esta bacteria foi isolada das fezes dos pacientes na fase aguda. O primeiro desses surtos acorreu em 1975 e foi atribuldo ao consumo de "sashimi" por 5 pessoas de uma mesma familia, das quais 4 apresentaram diarreia aquosa e dores abdominais. 0 segundo surto, ocorrido em 1977, em Lima escola 
primaria, envolveu 29 individuos de 37 que consumiram um almoço nessa escola, sendo o alimento causador do surto, desconhecido. Dos 29 individuos doentes, apenas 8 apresentaram diarréia, sendo a mesma năo aquosa, com a presença de muco em 3 e de sangue em 2 . Dos 29 individuos doentes, foram relatadas dores abdominais em 23 , vomitos em 24, febre em 14, nauseas em 8, dores de cabeça em 5 e anorexia em 17.

5. Fatores de virulencia das Aeromonas do grupo

\section{A. hydrophila}

CALLISTEF \& AGGEF (1987) afirmam que a A. hydrophila pode ser considerada um patógeno enterico, luma vez que diversos fatores extracelulares de virulencia descritos sustentam as associaçós epidemiologicas. Atraves da utilizaçăo das técnicas de inoculaçăom alça intestinal ligada de coelho (SANYAL et al., 1975), inoculaçăo em camundongos lactentes (BURKE et al., 1981), perfusao em jejuno de rato "in vivo" (THELEN et al.s 1978) e de culturas de células (CUMBERBATCH et al. 1979), foi verificada a producão de enterotoxina por cepas de $A$, hydrophila. JIWA (1983) sugere que a hidrofobicidade da superficie da célula pode ser um determinante para que a fixaça no intestino ocorra.

\footnotetext{
SANYAL et al. (1975), utilizando o teste em alça intestinal de coelho adulto, verificaram um acúmulo de
} 
fluido de 1,0 a $2,0 \mathrm{ml} / \mathrm{cm}$ de comprimento de alca, usando um indculo de apenas $104 \mathrm{~A}$. hydrophila viaveis e concluiram que essa bacteria era enteropatogenica. ANNAFURNA \& SANYAL (1977) retomaram esse estudo e verificaram que 47 de 50 cepas isoladas do homem e de seu ambiente produziam acúmulo de fluido. As tres cepas restantes eram tambem positivas, porém, apos duas passagens seriadas em alça ligada de coel ho.

LJUNGH et al. (1977) sugeriram a classificaçao das enterotoxinas das Aeromonas spp. como citotonicas e nao como citotoxicas, o que foi evidenciado por CHAKRABORTY et al. (1984) e por CHOPRA et al. (1986).

CUMBEREATCH et al. (1979) testaram 96 cepas de A. hydrophila e observaram que $69 \%$ eram produtoras de citotoxina e hemolisina e as restantes, negativas.

LJUNGH et al. (1981) afirmaram que a $A$. hydrophila produz uma enterotoxina e duas hemolisinas (alfa e beta), sendo a beta antes denominada aerolisina ou proteina citotóxica.

0 teste do camundongo lactente, para a deteç̣ă da enterotoxina termoestavel da $E$. coli (DEAN et al., 1972), foi considerado, por BURKE et al. (1981), adequado para a pesquisa da produçao de enterotoxina por cepas de A. hyorophila. 
Enquanto $A S A O$ et al. (1984) purificaram uma toxina e a descreveram como hemolisina com atividade enterotoxica citotóxica, NOTERMANS et al. (1986) concluiram que a A. hydrophila produz um outro fator citotóxico sem atividade hemolitica.

BURKE et al. (1984a) observaram relaçăo entre a hemaglutinạ̧ăo a presença de diarréia em crianças. Assim, esses pesquisadores sugeriram que as hemaglutininas fossem consideradas como fatores de virulencia das Aeromonas spp." ao lado das enterotoxinas.

HONDA et al. (1985) verificaram a produça de um fator imunologicamente relacionado a enterotoxina colerica por cepas de $A$. hydrophila e de $A$. sobria, que era diferente da hemolisina e da toxina ativa no teste do camundongo lactente. A presença de uma toxina semelhante à colerica tambem foi demonstrada por SCHULTZ \& MCCARDELL (1988), utilizando provas geneticas especificas.

CHOFRA et al. (1986) sugeriram a existencia de duas enterotoxinas diferentes quanto à sensibilidade termica, sendo a termolabil interreativa com a anti-toxina da colera.

STELMA Jr. (1988) sugere que essa toxina não seja denominada de "toxina semelhante à colerica" "mas de "fator interreativo com a toxina colerica", como denominado por CAMFBELL \& HOUSTON (1985), uma vez que a semelhanca dessa 
toxina com a colérica pode ser pequena, envolvendo apenas um sitio antigenico em comum.

NISHIKAWA \& KISHI (1988) afirmam que a hemolisina nao é um fator único de virulencia, tendo em vista que, no estudo de MORGAN et al. (1985), cepas hemoliticas näo provocaram diarréia em voluntarios humanos. Segundo NISHIKAWA \& KISHI (1988), embora a maioria das cepas de $A$. hydrophila e de A. sobria produzam beta-hemolisina, poucas possuem adesina e apenas uma pequena proporça de humanos possuem celulas epiteliais intestinais sensiveis à adesina. Segundo os autores, isso poderia explicar a rara ocorrencia de surtos por essas bactérias.

CAFRELLO et al. (1988) verificaram uma relaçăontre diarreia $e$ um alto grau de adesão a cellulas HEp-2 e concluiram que a aderencia de Aeromonas spp. pode ser mediada por pilus.

GRAY et al. (1990) constataram uma relaçao entre a produça de citotoxina e o efeito de alongamento de células CHO-KI, para cepas de Aeromonas spp. isoladas de animais de criaça e de seu ambiente.

BORFEGO et al. (1991) verificaram que mais de $90 \%$ das cepas de $A$, hydrophila isoladas de peixes, moluscos, agua do mar e agua doce, eram hemoliticas e produziam sideroforos. Eles sugerem, como um possivel papel das hemolisinas na patogenicidade da $A$. hydrophila, o aumento da 
biodisponibilidade do ferro para essa bacteria atraves da lise dos eritrocitos.

CHofía et al. (1992) sugerem que o mecanismo de açăo da enterotoxina citotonica da $A$. hydrophila envolve a ativaçă da adenilciclase, resultando na elevaça dos niveis intracelulares de AMP ciclico, a exemplo da toxina colerica (CT) e da LT-I da E. coli.

Quanto à capacidade de invasăo do epitelio intestinal pelas Aeromonas spp., LAWSON et al. (1985) e WATSON et al. (1985) verificaram que diversas cepas de A. huorophila, isoladas de fezes, eram invasivas em células HEp-2.

Muitas evidencias clinicas e epidemiologicas conduzem à idéia afirmativa sobre a enteropatogenicidade das Aeromonas moveis, particularmente de A. hydrophila, o que é confirmado em muitos estudos sobre a produça de fatores de virulencia, entre eles o de FALUMBO et al. (1989). MORGAN \& WOOD (1988), entretanto, sugerem a necessidade da reprodução do quadro de gastrenterite em modelos experimentais, envolvendo primatas ou voluntarios humanos. Deve ser salientado que fit et al. (1982) e MORGAN et al. (1985), em estudos em primatas e em voluntarios humanos, respectivamente, nåobtiveram o resultado esperado, apos a ingestao de Aeromonas spp., mesmo em números elevados ( 109 e até 1010 , respectivamente).

MAJEED et al. (1990) aventam a possibilidade das Aeromonas enterotoxigenicas causarem gastrenterite, apos a 
ingestå de toxina préformada em alimentos contaminados. Isso explicaria, nå apenas os resultados nå satisfatorios, tanto em macacos quanto no homem, mas também o curto periodo de incubacão, de até 12 horas, em alguns casos. Os autores salientam, tambem, o fato da maioria dos casos de gastrenterite por Aeromonas spp. terem sido associados à ingestao de alimentos congelados, manipulados de maneira incorreta. Entretanto, TODD et al. (1989), enumeraram casos em que o periodo de incubaçao variava de 6 a 36 horas, considerando-os mais longos do que o esperado para intoxicaçoses por toxina préformada.

KROVACEK et al. (1991) observaram que cepas de A. hydrophila e de $A$. sobria, isoladas de peixe e de água potavel, cresciam e produziam citotoxina, enterotoxina $e$ hemolisina a $4 \circ \mathrm{C}$.

MAJEED \& Mac FAE (1991) obtiveram a produça de enterotoxina e hemolisina em extrato de carne a baixas temperaturas por cepas de A. hydrophila e A. sobria. Eles salientam a importancia desses resultados, uma vez que o armazenamento de alimentos sob refrigeraço năo impede a produça de toxinas pelas Aeromonas spp. e um pequeno aumento de temperatura possibilita tal produça mais rapidamente.

ARCHEF \& KVENBEFG (1988) comentam que, apesar das Aeromonas spp. possuirem muitos dos mesmos fatores de virulencia que outras bacterias patogenicas possuem, falta 
alguma peça nesse "quebra-cabeca", que pode estar relacionada a um possivel potencial invasivo ou à presença de um fator de colonizaço.

TODD et al. (1989), por outro lado, consideram que a A. hyorophila pode diferir de muitos microrganismos tradicionais, causadores de toxinfectoges de origem alimentar. Segundo os autores, é possivel que as toxinas e enzimas por ela elaboradas não causem gastrenterite, mas sim, produzam condiçass de superficie apropriadas que podem facilitar o estabelecimento desses microrganismos no intestino delgado e auxiliar sua adesăo e/ou invasă.

WADSTFOM \& LJUNGH (1991), por sua vez, comparam a complexidade do potencial patogenico das Aeromonas spp. ao da E. coli, sugerindo a existencia de microrganismos enterotoxigenicos, enteroinvasivos e enteroaderentes. No entanto, as Aeromonas spp. diferem da E. coli na medida em que os fatores de virulencia podem manifestar-se em conjunto, de uma maneira bastante complexa. Os autores ilustram essa observaçao atraves da comparaçăo das manifestaços clinicas variadas de gastrenterite causada por Aeromonas spp. com as produzidas por Campylobacter jejuni.

6. Aeromonas do grupo A. hidrophila e a seguranca de alimentos

BUCHANAN E PALUMBO (1985) salientam a necessidade de se verificar o significado da A, hydrophila e da A. sobria no que se refere à segurança de alimentos. Ao mesmo tempo; 
destacam o fato de 56 a $70 \%$ das toxinfecçes de origem alimentar nos Estados Unidos serem classificadas como sendo de etiologia desconhecida. Segundo esses pesquisadores, o aumento do conhecimento sobre as causas das doencas diarrécas, particularmente no que se refere ao papel das enterotoxinas e a outros fatores de virulencia, levou a uma expansåo significativa da lista de bacterias classificadas como causadoras em potencial de toxinfecços alimentares. Esses mesmos autores propae a inclusao de $A$. hydrophila e A. Sobria como patogenos de importancia no que se refere à segurança de alimentos.

Com uma preocupaçå visivel em termos de vida lutil de produtos industrializados e o risco que podem representar, particularmente os mantidos sob refrigeraça, diversos pesquisadores vem testando novas maneiras de inibir: injuriar ou destruir diversos tipos de bacterias, especificamente as consideradas psicotróficas. E o que $x$ ocorre no caso das Aeromonas spp.

Assim, FALUMBO et al. (1985b) verificaram que a maioria das cepas de $A$. hydrophila por eles testadas resistia a $4 \%$ de cloreto de sodio a $280 \mathrm{C}$ e que apenas um pequeno número de cepas crescia a $4{ }^{\circ} \mathrm{C}$ a uma concentraça de cloreto de sodio de $3 \%$. Tambem verificaram que as cepas de A, hydrophila testadas toleravam condiçoes acidas a $28 \circ \mathrm{C}$ mais do que a 40C. Os autores comentam que cepas de A. hydrophila associadas à gastrenterite humana possuem a capacidade de crescer em alimentos mantidos a temperaturas de 
refrigeraça, normalmente consideradas adequadas para a prevenção do crescimento de patogenos de origem alimentar. For outro lado, PALUMBO (1986) ressalta a importancia das bacterias psicotróficas, dentre as quais a A. hydrophila, salientando a necessidade de uma revisão quanto ao conceito de que uma refrigeraça adequada (50C) garante a segurança de um alimento. A conservaça a $50 \mathrm{C}$ apenas retarda o crescimento de varios patogenos que podem estar presentes nos alimentos, assim como ocorre com os microrganismos deteriorantes. O mesmo autor salienta a necessidade de se levar em conta esses conceitos durante a formulaçao de produtos que seræa mantidos sob refrigeraçă.

PALUMBO et al. (1987), em um estudo sobre a resistencia termica da A. hydrophila, concluiram que os tratamentos termicos recomendados para eliminar Salmonella spp. devem ser suficientes para A. hyorophila, mas admitiram a necessidade de investigaçoes sobre o significado de subpopulaçöes termoresistentes.

CONDON et al. (1992) estudaram os efeitos da idade da cultura, da pre-incubaçao a baixas temperaturas e do pH sobre a resistencia termica da $A$. hyorophila. Eles salientam que, apesar dos dados de inativaçă termica sugerirem que as etapas normais de processamento de alimentos, como a pasteurizaçå ou o cozimento, săo suficientes para eliminar A. hydrophila, é recomendavel năo negligenciar a importäncia prática da populaçăo viável residual. 
FALUMBO \& BUCHANAN (1988) fizeram luma revisão das diversas medidas de controle do crescimento de $A$, hyorophila em alimentos e de sua destruifáa atraves do calor, da irradiaça e do uso de produtos químicos.

Trabalhando com verduras contaminadas experimentalmente, BERRANG et al. (1989) verificaram que o armazenamento sob atmosfera controlada, apesar de prolongar - tempo de aceitabilidade subjetiva para o consumo, não afetou significativamente a populaça de $A$. hydrophilas a qual sobreviveu ou cresceu nas verduras mantidas nessas condi çöes.

FARBER (1991) verificou que a $A$, hyorophila é capaz de crescer a temperaturas de refrigeraça a determinados tipos de acondicionamento sob atmosfera modificada. Anteriormente, BLICKSTAD \& MOLIN (1983) já haviam observado que 口 armazenamento sob $\mathrm{CO}_{2}$ a temperaturas de refrigeraço mais elevadas pode aumentar o risco quanto ao desenvolvimento de Aeromonas spp.

FALUMBO et al. (1991, 1992b) realizaram uma pesquisa sobre o crescimento de uma cepa de $A$. hydrophila (k144) em condiçoes de aerobiose e anaerobiose. Verificaram que o $\mathrm{pH}$, - cloreto de sodio e o nitrito de sodio podem reduzir o crescimento de $A$. hydrophila quando combinados a baixas temperaturas de incubaçăo e anaerobiose. Forem constataram que algumas variáveis de cultivo que nå permitiam o crescimento da $A$. hydrophila em anaerobiose o permitiam em aerobiose (F'ALUMBO et al., 1992b). 
0 efeito de conservantes quimicos sobre o comportamento da Aeromonas spp., por sua vez, tambem tem sido estudado (GRAM, 1991; MOIR \& EYLES, 1992; PALUMBO \& WILLIAMS, 1992a). ARCHEF \& KVENBERG (1988) salientam a necessidade de se considerar niveis detectaveis de A. hydrophila em alimentos destimados a pacientes hospitalizados, portadores de cancer ou a pessoas recebendo tratamento quimioterapico contra o cancer, como perigosos e, provavelmente, pondo em risco a vida dessas pessoas.

No que diz respeito a alimentos destinados a individuos sadios, ARCHER \& KVENEERG (1988) afirmam que a patogenicidade das Aeromonas necessita ser melhor estabelecida, a fim de que se possa tomar medidas regulatorias baseadas em riscos à saúde. No entanto, esses pesquisadores admitem a preocupaça, tanto para órgås fiscalizadores, como para a indústria de alimentos, em termos de potencial de crescimento dessas bacterias aे temperatura de refrigeraça, frente a alta probabilidade dessas bactérias causarem gastrenterite.

De qualquer modo, por maior que seja a controversia em relação ao mecanismo de açăo das Aeromonas spp. como causadoras de distúbios gastrintestinais, as diversas linhas de pesquisadores são unänimes em considerar que essas bacterias podem ser agentes potenciais de gastrenterite veiculada por alimentos, devido à sua larga distribuiça, aliada à sua natureza psicrotrofica. 
- problema das Aeromonas spp. serem capazes de crescer a temperaturas de refrigeracar, outrora consideradas adequadas para o armazenamento de muitos produtos alimenticios, pode ser ainda mais agravado pela possibilidade dessas bactérias serem capazes de produzir toxinas tambem a essa temperatura, conforme observado por diversos autores, entre eles MAJEED et al. (1990, 1991) e KROVACEK et al. (1991).

$$
\text { Essa natureza psicrotrofia das Aeromonas spp. }
$$
produtoras de citotoxinas é de grande interesse para os microbiologista de alimentos e para os sanitaristas. Isto se deve à ampla presença dessas bactérias em alimentos que podem ser consumidos crus, como verduras, vendidos no varejo, que săo armazenados sob refrigeraçao por um longo periodo de tempo, inclusive durante seu transporte e comercializaçå (BEUCHAT, 1991). 


\title{
II. QBJETIVOS
}

\begin{abstract}
Com base no exposto no capitulo anterior, pode-se depreender que as bacterias do genero Aeromonas, sobretudo as do grupo A. hydrophila, tem sido consideradas, por muitos autores, patogenos emergentes causadores de infecçores por vezes graves, incluindo gastrenterites, conferindo a esses microrganismos uma crescente importancia.

Assim, tendo em vista que no Brasil, o número de estudos a respeito é extremamente escasso e o risco que hortalicas frequentemente consumidas cruas e em larga escala, como alface, agriăo e escarola, podem oferecer, planejou-se a presente investigaça, que tem como objetivos:
\end{abstract}

1) Verificar a ocorrencia de Aeromonas do grupo A. hydrophila em amostras de alface, agriă e escarola, adquiridas no comércio da cidade de Sao Faulo, atraves da contagem dessas bactérias em placas e a sua deteção pelo teste de presença/ausencia.

2) Comparar as positividades obtidas for ambos os processos de isolamento empregados.

3) Identificar as especies das cepas de Aeromonas spp. isoladas. 
III. MATERIAL E METODOS

\title{
1. Colheita das amostras de hortalicas para análise
}

\begin{abstract}
Nas condiçoes de consumidor, foram obtidas, no perlodo de fevereiro de 1991 a maio de 1992,90 amostras de hortaliças, sendo 30 de alface, so de agriăo $e$ so de escarola. Na maioria das vezes, foram colhidas amostras dos trés tipos de hortaliças, simultaneamente, no mesmo ponto de venda. Tais amostras foram adquiridas em locais de venda no varejo, incluindo 10 supermercados, 4 feiras-livres, 3 sacologs e 3 quitandas, de 7 bairros situados, em grande parte, na zona oeste da cidade de Săo Paulo.

Logo após a sua obtençå, as amostras foram levadas para o laboratorio e o tempo decorrido entre a sua colheita e infcio da analise, na quase totalidade das vezes, nă excedeu de 2 horas. Excepcionalmente eram obtidas amostras para serem analisadas na manhã do dia seguinte.
\end{abstract}

\section{Preparo das amostras ee de suas diluicbes}

Para a realizaça das analises, para cada amostra,
inicialmente, eram pesados 259 de folhas visualmente
aceitácis para o consumo e obtidas de varias camadas e
colocados em um copo esterilizado de liquidificador, seguido


da adiça de $225 \mathrm{~mL}$ de soluçăo salina peptonada a 0,1\% esterilizada. Procedia-se a liquidificaça por cerca de 3 minutos e, a partir do homogeneizado inicial a $10^{-1}$, era preparada uma serie de diluiçoes decimais até 10-0, empregando-se o mesmo diluente (CALLISTER \& AGGER, 1987).

\section{Contagem e teste de presenca/ausencia de Aeromonas do} grupo A. hydrophila

\subsection{Semeadura inicial das amostras}

A fim de proceder a contagem dessas bacterias, na semeadura inicial, eram depositados na superficie de agar amido-ampicilina (PALUMBO et al., 1985), em placas, 0,1 mL de cada diluị̧a. Fosteriormente, o inoculo era espalhado por toda a superficie do meio, empregando-se um bastao de vidro em "L" esterilizado. a espalhamento do inoculo era feito inicialmente na placa relativa à diluiçă $10^{-b} \mathrm{e}$, em seguida, nas diluiçoes subsequentes. As placas, assim semeadas, eram incubadas a $280 \mathrm{C}$ por 24 horas.

Faralelamente, para as mesmas amostras, realizava-se

- teste de presença/ausencia de Aeromonas spp., adicionando $10 \mathrm{~mL}$ da primeira diluiçăo de cada amostra $\left(10^{-1}\right)$ a um tubo de ensaio correspondente, contendo $10 \mathrm{~mL}$ de caldo tripticase-soja em concentraçao dupla, adicionado de $2 \mathrm{mg} / 100 \mathrm{~mL}$ de ampicilina. Após a inoculaçăo da diluiçăo 10-1 da amostra, a concentraçăo de ampicilina era de 
$1 \mathrm{mg} / 100 \mathrm{~mL}$ de meio. Em seguida, os tubos semeados eram incubados a $280 \mathrm{C}$ por $18-24$ horas.

Apos a incubaça, a partir de cada tubo, era realizada, com alça de níquel-cromo, a passagem em placas de agar amido-ampicilina por esgotamento, seguida de incubaçao a 2800 por 24 horas.

\subsection{Contagem e isolamento de colonias suspeitas}

Apos a incubaça, realizou-se, em placas com 30 a 300 colonias, a contagem do número de colonias suspeitas, ou seja, de cor amarela a mel e circundada por lum halo amarelo no agar amido-ampicilina e revelando um halo de transparencia ao seu redor apos a adiça de lugol, verificando-se, assim, a utilizaçăo do amido e a produço de acido.

- calculo presuntivo do número de UFC de Aeromonas spp. por grama do alimento foi realizado, multiplicando-se o número de colonias contado pelo fator de diluiçao correspondente à placa de contagem. A confirmaça desse resultado ou a sua correça era feita apos a identificaça das cepas referentes às colonias isoladas. De cada placa de contagem e de cada placa proveniente do pré-enriquecimento para o teste de presença/ausencia, eram isoladas até 5 colonias, com as caracteristicas descritas. 


\subsection{Identificaçă das cepas isoladas}

As provas de identificaça das cepas isoladas foram selecionadas com base nas recomendaçóes de diversos autores (FOFOFF, 1984; BUCHANAN \& FALUMBO, 1985; OKFEND et al., 1987; ABEYTA Jr. et al., 1989).

\subsubsection{Identificaçăo presuntiva}

Cada uma das colonias suspeitas isoladas do agar amido-ampicilina era semeada em tubos com agar tripticase-soja inclinado e em agar triplice-açucar-ferro, os quais eram incubados a $28^{\circ} \mathrm{C}$ por $18-24$ horas.

Após a incubaçăo no agar triplice-açúcar-ferro, as cepas suspeitas de Aeromonas spp. produzem acidificaço do apice, por serem sacarose-positivas, e acidificặo da base, por serem glicose-positivas, com ou sem produça de gás. Assim, as colonias que apresentavam esse comportamento no agar triplice-açucar-ferro, eram testadas para a produçao de oxidase e catalase a partir da cultura em agar tripticase-soja.

\subsubsection{Prova da oxidase}

Empregando uma alca de platina,
transferia-se uma porçăo da cultura de 24 horas em agar
tripticase-soja, para tiras de papel impregnadas com
reagente para oxidase (Difco). A prova era considerada
positiva quando havia formaçåo de uma coloraçă violeta na
região da tira onde havia sido aplicada a porçăo de cultura,




\title{
3.3.1.2 Prova da catalase
}

\begin{abstract}
For meio de uma alça de niquel-cromo, transferia-se uma porça da cultura de 24 horas em agar tripticase-soja para uma gota de água oxigenada a $3 \%$, previamente depositada em uma lamina de vidro. A prova era considerada positiva quando, após suave homogeinizạ̧a, observava-se a formaça de bolhas de gás.
\end{abstract}

As cepas positivas para a produçăo de oxidase e catalase e se revelando com comportamento caracteristico no agar triplice-açúcar-ferro eram consideradas suspeitas de serem Aeromonas. Estas cepas eram cultivadas em agar tripticase-soja a $280 \mathrm{C}$ por 24 horas e, em seguida, mantidas em temperatura ambiente a fim de serem, posteriormente, submetidas as provas de identificaçăo definitiva.

\subsubsection{Identificaçăo definitiva}

A partir de culturas em agar tripticase-soja inclinado a $280 \mathrm{C}$ por $18-24$ horas eram feitos esfregaços corados pelo metodo de Gram e os testes de motilidade, reduça de nitrato, produçăo de indol em água peptonada a 1\% ,fermentaça/oxidaça da glicose, colorạ̧ăo de flagelo em cultura em meio sólido, crescimento em caldo nutriente a $370 \mathrm{C}$, crescimento em meio contendo 0,3 e $6 \%$ de cloreto de sodio, utilizaçao de sacarose, manitol, inositol, salicina e arabinose, produça de gás a partir da glicose, produça de 


\begin{abstract}
acetoina (prova de Voges-Froskauer), hidrolise da esculina e utilização da arginina, ornitina e lisina.
\end{abstract}

\title{
3.3.2.1 Coloraçăo de Gram
}

De cada cepa isolada, partindo-se das culturas em agar tripticase-soja inclinado a $280 \mathrm{C}$ por $18-24$ horas, eram preparados esfregaços corados pelo método de Gram, a fim de se observar a morfologia bacteriana microscópica, assim como verificar a sua pureza.

As cepas isoladas de Aeromonas do grupo A. hydrophila apresentavam-se como bacilos Gramnegativos de forma e tamanho variaveis, sendo, na maioria das vezes, curtos a cocbides, mas podendo se apresentar como celulas mais longas e ate filamentosas (FOFOFF, 1984).

\begin{abstract}
3.3.2.2 Prova da motilidade (TITTSLER \& SANDHOLZER, 1936)

Fara a realizaça desta prova, as cepas isoladas eram semeadas, por meio de uma agulha de niquel-cromo, em ágar semi-solido para a deteç̣ăo da motilidade. a ináculo era introduzido por picada até uma altura equivalente à metade da altura da coluna de agar. A prova era considerada positiva quando, apos a incubaça a $280 \mathrm{C}$, por 24 horas, se observava um crescimento difuso.
\end{abstract}




\title{
3.3.2.3 Prova da reduçăo de nitrato (ICMSF,
}

\begin{abstract}
1978)
As cepas em identificaçă eram inoculadas em caldo nitratado, seguido de incubaçao a $280 \mathrm{C}$ por 48 horas. A seguir, adicionava-se $0,5 \mathrm{~mL}$ de soluça de acido sulfanilico (A) e $0,5 \mathrm{~mL}$ de solugao de alfanaftilamina (B). A prova era considerada positiva quando ocorria o desenvolvimento de cor vermelha, indicando a presença de nitrito. Em caso de prova negativa, a mesma era repetida, utilizando-se um tempo maior de incubação, de 3 5 dias.
\end{abstract}

\subsubsection{Prova da producăo de indol (ICMSF,} 1978)

A verificaçao da sintese de indol a partir do triptofano, era realizada adicionando-se, vagarosamente, uma pequena quantidade de reativo de Ehrlich, a uma cultura de 24 horas a $28^{\circ} \mathrm{C}$ em agua peptonada a $1 \%$. A prova positiva era indicada pela formaça de um anel de cor púrpura.

\footnotetext{
3.3.2.5 Prova da fermentagáo/ oxidaça da glicose (HUGH \& LEIFSON, 1953)

Fara a realizaça desta prova, as cepas isoladas eram semeadas, simultaneamente, em dois tubos contendo meio basal of adicionado de $1 \%$ de D-glicose. Um deles era previamente aquecido em banho-maria fervente por
} 
15 minutos e, em seguida, esfriado e adicionado de uma camada de vaselina liquida esteril, a fim de se manter as condiços de anaerobiose. A semeadura era feita por picada do meio em profundidade, empregando-se para isto uma agulha de niquel-cromo longa, e a leitura da prova era feita apos a incubaça a $280 \mathrm{C}$, por 24 horas.

A utilizaçăo da glicose, tanto por mecanismo oxidativo quanto fermentativo, era indicada pela mudança de coloraçå do meio de cultura de verde para amarelo, consequente à formaçăo de acido proveniente da degradação da glicose.

\subsubsection{Coloraçăo de flagelo em cultura em} meio solido (HEIMBFOOK et al., 1989)

A fim de que a presença de flagelos polares monotriquios pudesse ser detectada nas Aeromonas móveis isoladas, encostava-se, leve e cuidadosamente, uma agulha de niquel-cromo na borda do crescimento bacteriano em agar tripticase-soja. Em seguida, transferia-se esse material, delicadamente, para uma gota de agua destilada, depositada sobre uma lamina nova, limpa e desengordurada e, a seguir, cobrindo-se, com todo o cuidado, com uma laminula, tambem nova e limpa.

Apos um intervalo de pelo menos 15 minutos de repouso, com seringa e agulha fina, depositava-se - corante de fiyu na borda da laminula, sendo que o mesmo penetrava por capilaridade. Decorrido um intervalo de pelo 
menos so minutos apos a injeçao de corante, a preparaçăo era examinada em microscopio optico comum, com objetiva de imersão, Litilizando-se um aumento de 1200 vezes.

\subsubsection{Crescimento em caldo nutriente a 370C} As cepas em teste eram inoculadas em caldo nutriente, seguido de incubaçăo a $370 \mathrm{C}$ por 24 horas. A prova era tida como positiva, quando ocorria crescimento.

\subsubsection{Crescimento em 0,3 e $6 \%$ de cloreto de sodio}

As cepas em identificaçao eram

semeadas em tubos com caldo tripticase-soja contendo diferentes concentraçores de cloreto de sodio, a fim de verificar a interferencia da ausencia $(0 \%)$ do sal e de sua presença em concentraçøes de $3 \%$ e $6 \%$,sobre o crescimento da bacteria. No caso da concentraçăo $0 \%$,foram utilizados também tubos com caldo nutriente, uma vez que este meio de cultura nåo possue cloreto de sodio, ao contrario do que ocorre com o caldo tripticase-soja, que contém em sua formulaçสัด $0,5 \%$ desse sal.

Os tubos inoculados eram incubados a $28^{\circ} \mathrm{C}$ por 24 horas, sendo que na presença de crescimento a uma determinada concentraça de cloreto de sodio, a prova em queståo era considerada como sendo positiva. Caso contrario era tida como negativa. 


\subsubsection{Utilizaçăo de sacarose, manitol,} inositol, salicina e arabinose

As cepas isoladas eram cultivadas em

tubos contendo caldo base vermelho de fenol adicionado de 0,5\% dos diferentes açucares. A utilizạ̧ăo do carboidrato em questao (prova positiva) era detectada pela acidificaçăo do meio, visualizada pela mudança de coloraçăo do meio de vermelha para amarela. As leituras eram realizadas apos a incubaçăo a $280 \mathrm{C}$, por 24 horas.

\subsubsection{Produça de gás a partir da glicose}

As cepas isoladas eram inoculadas em tubos de caldo vermelho de fenol adicionado de $0,5 \%$ de glicose contendo, no seu interior, tubos de Duhram invertidos. Essa prova era considerada positiva quando, alem da mudança de coloraçao de vermelha para amarela, havia a formaça gas no interior do tubo de Duhram. A leitura da prova tambem era feita após a incubaçao a $280 \mathrm{C}$, por 24 horas.

\subsubsection{Prova de Voges-Proskauer (AFHA, 1992)}

As cepas em identificacăo eram inoculadas em meio Clark-Lubs e incubadas a $28^{\circ} \mathrm{C}$, por 48 horas. Na leitura da prova, a $1,0 \mathrm{~mL}$ de meio de cultura, adicionava-se $0,6 \mathrm{~mL}$ de soluçao de alfa-naftol a $5 \%$ e 0,2 mL de hidráxido de potássio a $40 \%$,seguido de leve aquecimento e agitaçă A prova era considerada positiva, quando ocorria 
- aparecimento de uma coloraça avermelhada, indicando a presença de acetoina.

\title{
3.3.2.12 Hidralise da esculina (Mac FADDIN,
} 1976)

\begin{abstract}
Na realizạ̧a desta prova, as cepas em identificaço eram estriadas na superficie de agar bileesculina inclinado, também denominado meio fifizer. A capacidade de hidrolizar a esculina por parte de determinadas bactérias e, portanto, a positividade para essa prova, era revelada pelo escurecimento do agar, passando at cor marrom escura ou preta, na superficie ou, na maioria dos casos, também em profundidade. Essa leitura era feita após a incubaça a $280 \mathrm{C}$, por 24 horas.
\end{abstract}

\subsubsection{Utilizasăo da arginina, ornitina e} lisina (Mac FADDIN, 1976)

Nestes testes, as cepas isoladas eram inoculadas em tubos com meio de Falkow adicionado de 0,5\% de L-arginina, L-ornitina e L-lisina, respectivamente. Simultaneamente, realizavam-se as provas controle, Ltilizando-se tubos contendo apenas a base de Falkow, sem a adiçă dos amino-kcidos. Todos os tubos contendo meios de prova e controle eram adicionados de uma camada de vaselina liquida, a fim de impedir a oxidaça alcalina do meio. Os tubos inoculados eram incubados a $28^{\circ} \mathrm{C}$ e as leituras eram realizadas após 48 e 96 horas. 


\begin{abstract}
As provas eram consideradas positivas quando a cor do meio controle passava de violeta para amarelo, revelando a utilizaça de glicose com consequente acidificaçăo do meio, enquanto que o tubo contendo o aminoacido em questå passava novamente a cor violeta pela neutralizaça do $\mathrm{pH}$ acido por aminas resultantes da descarboxilaçăo do amino-ácido. A prova era considerada negativa, quando o meio controle e o meio contendo o aminoacido, mostravam-se de cor amarela, devido apenas at utilizaçăo da glicose.
\end{abstract}

\title{
3.3.2.14 "CAMP-TEST"
}

Após a realizaçăo das provas de identificaçăo descritas, as cepas caracterizadas como sendo de Aeromonas do grupo A. hydrophila e classificadas numa das especies deste grupo de bacterias, foram submetidas ao "CAMF-TEST" (CHRISTIE, ATKINS \& MUNCH-PETERSON, 1944; KONEMAN et al., 1988), para a pesquisa da produçao de um fator semelhante ao de CAMF, com base no estudo realizado por FIGURA \& GUGLIELMETTI (1987).

Fara a realizaça do teste, eram utilizadas placas de agar sangue constituido de agar Colúmbia adicionado de $5 \%$ de sangue desfibrinado de carneiro. Em cada placa de agar sangue, era semeada em uma única estria, uma cultura em caldo tripticase-soja a $370 \mathrm{C}$ por 24 horas, de uma cepa alfa-hemolitica de staphylococcus aureus. Em seguida, cada cepa de Aeromonas spp. a ser 


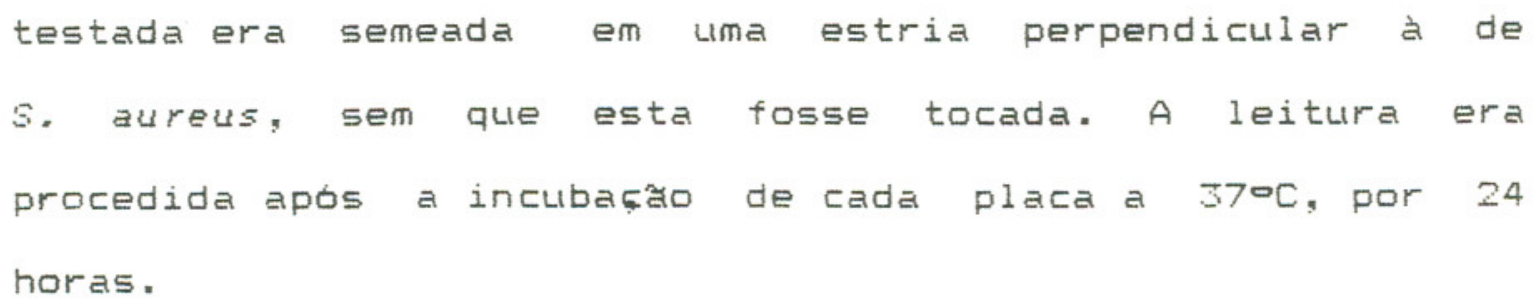

Fara essa prova, eram inoculadas duas placas de agar sangue, sendo uma incubada em aerobiose e a outra, em anaerobiose. Segundo FIGURA \& GugLIELMETTI (1987), A. hyorophila produz o fator por eles denominado "semelhante ao CAMF" tanto em aerobiose quanto em anaerobiose, enquanto que $A$. sobria so o faz em aerobiose e $A$. caviae, por sua vez, năo produz esse fator em nenhuma das duas condiçđes.

A figura 1 mostra o fluxograma seguido para as contagens e os testes de presença ou ausencia de Aeromonas spp. a partir das amostras de hortalicas analisadas e na tabela 1 sào apresentados os comportamentos esperados para diferentes espécies, nos testes de identificaçao das cepas isoladas. 

Figura 1 Fluxograma de isolamento $e$ identificaçăo presuntiva de Aeromonas do grupo A. hydrophila a partir de hortaliças.

\section{AMOSTRA $(25 \mathrm{~g})$}

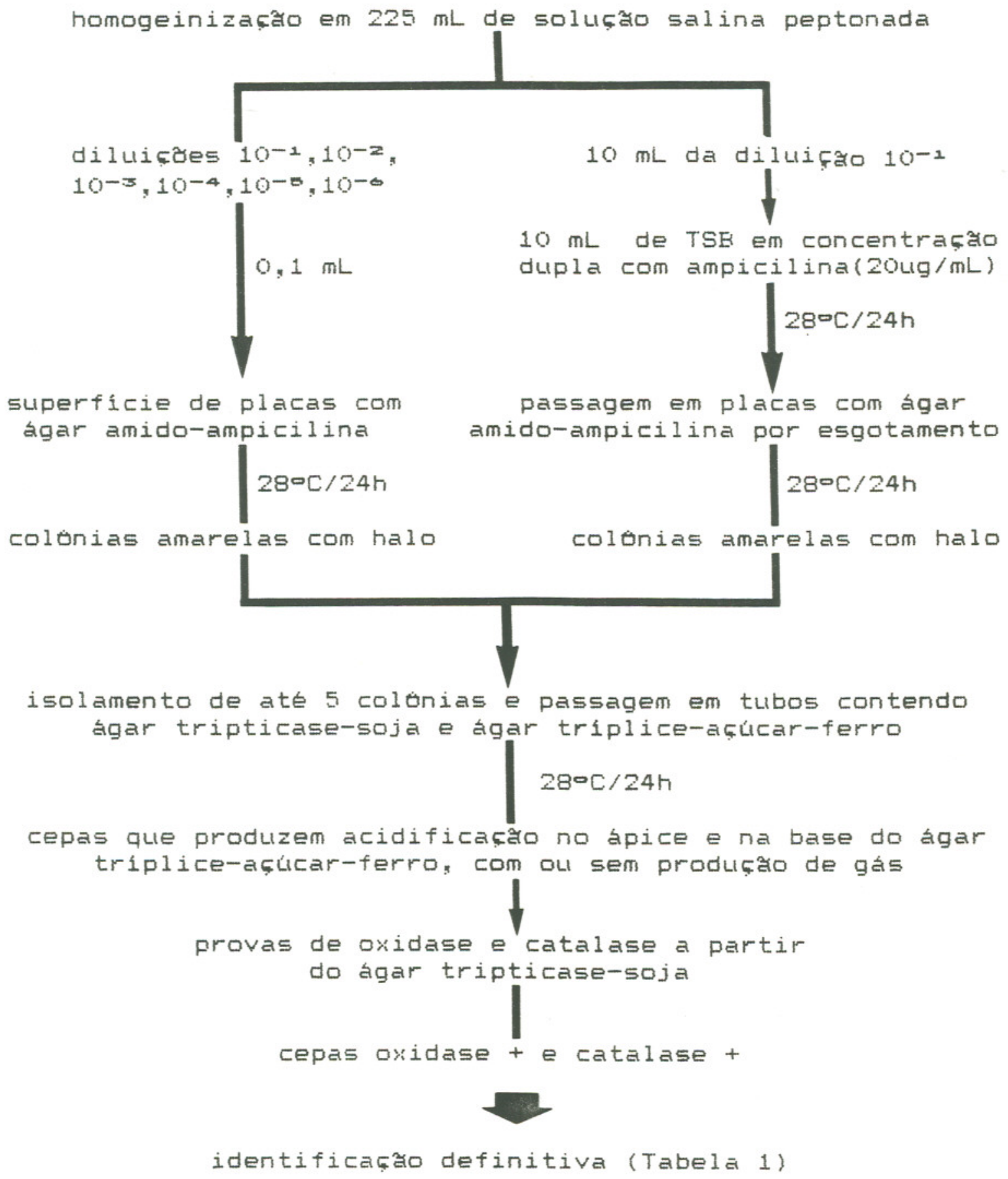


Tabela 1 Frovas bioquímicas e microscopicas utilizadas na identificação das cepas isoladas de amostras de hortaliças comercializadas em Să Faulo e resultados esperados para diferentes espécies de Ae romonas.*

Testes

A. hydrophila A. caviae

A. sobria A. veronit

\begin{tabular}{|c|c|c|c|c|}
\hline \multicolumn{5}{|l|}{ Bacilo } \\
\hline Gram - & + & + & + & + \\
\hline Motilidade & + & + & + & + \\
\hline Nitrato & + & + & + & + \\
\hline Indol & + & + & + & + \\
\hline Glicose $0 / F$ & $+1+$ & $+1+$ & $+1+$ & $+1+$ \\
\hline $\begin{array}{l}\text { Flagelo polar } \\
\text { Crescimento }\end{array}$ & + & + & + & + \\
\hline $\begin{array}{c}\text { a } 370 \mathrm{C} \\
\text { Crescimento } \\
\text { em NaCl a }\end{array}$ & + & + & + & + \\
\hline $0 \%$ e $3 \%$ & + & + & + & + \\
\hline $6 \%$ & - & - & - & - \\
\hline Utilizạ̧ão de & & & & \\
\hline Sacarose & + & + & + & + \\
\hline Manitol & + & + & + & + \\
\hline Inositol & - & - & - & - \\
\hline Salicina & + & + & - & + \\
\hline Arabinose & + & + & - & - \\
\hline Esculina & + & + & - & + \\
\hline $\begin{array}{c}\text { Produçao de gás } \\
\text { a partir da }\end{array}$ & & & & \\
\hline glicose & + & - & + & + \\
\hline $\begin{array}{l}\text { Voges-Froskauer } \\
\text { Utilizacăo de }\end{array}$ & + & - & variável & + \\
\hline Arginina & + & + & + & - \\
\hline Ornitina & - & - & - & + \\
\hline Lisina** & variavel & variável & variável & + \\
\hline
\end{tabular}

- Segundo FOFOFF (1984), HICKMAN-BRENNEF et al.(1987), e CARINAHAN et al. (1991).

** CARNAHAN et al.(1991) consideram as cepas de origem clinica de $A$, hydrophila, A. sobria (ou $A$. veronit bv. sobria) e $A$. veronii (ou $A$, veronii bv. veronii) positivas para a utilizaçao da lisina e A. caviae, negativas. 


\section{RESULTADOS E DISCUSSAO}

Qs resultados da determinaçăo da presença ou ausencia e da contagem das Aeromonas do grupo A. hydrophila nas 90 amostras de hortaliças analisadas, assim como as espécies isoladas de cada uma, encontram-se distribuidos na tabela 2 .

Enquanto a tabela 2 agrupa os resultados obtidos de acordo com a ordem das amostragens, alternando os trés tipos de hortaliças, nas tabelas 3,4 e 5 são apresentados os resultados obtidos para as 30 amostras de alface, 30 de agriă e 30 de escarola, respectivamente.

As referidas tabelas mostram que os trés tipos de hortaliças analisados revelaram a presença de Aeromonas do grupo A. hydrophila por uma ou por ambas as metodologias utilizadas. Essas bactérias foram encontradas em $43(47,8 \%)$ das 90 amostras de hortalicas analisadas. Das 30 amostras de cada tipo de hortalica analisado, $13(43,3 \%)$ de alface, 21 $(70 \%)$ de agrião e $9(30 \%)$ de escarola revelaram-se positivas para Aeromonas spp. Com relaçăo a essas positividades obtidas para os diferentes tipos de hortaliças analisado e aplicando-se o teste de duas proporçőes com aproximaçăo pela distribuiçăo normal, a nivel de $5 \%\left(z_{2}+2=1,96\right)$ (BERQUO et al., 1981), verificou-se que a presenca de Aeromonas do grupo $A$. hydrophila revelou-se significativamente maior no agriào, quando comparada à escarola e à alface. For outro lado, para as amostras de alface e escarola, a diferença 
entre os percentuais de positividade nao se mostrou estatisticamente significante, tambem a nivel de $5 \%$.

Conforme pode ser observado nas tabelas 2 a 5 es sobretudo, na b, a contagem de Aeromonas spp. nos diferentes tipos de hortaliças analisados variou de $<10 z$, correspondendo ao limite mínimo de deteç̣ă da metodologia Ltilizada para a contagem dessas bacterias, a $2,0 \times 10^{\circ}$ UFC/g. Com relaça aos diferentes tipos de hortalicas, essa contagem variou de $<10^{2}$ a $2,0 \times 10^{\circ}$, de $<10=$ a $2,0 \times 10^{\circ}$ e de $<\quad 10=$ a $2,1 \times 10^{4}$ UFC/g nas amostras de alface, agriao $e$ escarola, respectivamente. Essas variaçôes de contagens săo ressaltadas na tabela b, a qual mostra, tambem, os valores da mediana e das médias aritmetica e geometrica dos resultados, para cada tipo de hortaliça analisado.

Fode-se observar, nessa tabela, uma acentuada discrepancia entre as diversas variáveis estatisticas das contagens obtidas para os diferentes tipos de hortalicas, bem como para o total de amostras analisado. Esse fato pode ser explicado pelo grande número de amostras com resultados de contagens $\langle 10 \%(68,9 \%)$, ao lado de números de UFC/g mais elevados e, em alguns casos $(3,3 \%)$, iguais ou superiores a 100/g (tabela 7). E sabido que a média aritmética é influenciada pela variaça dos valores extremos, podendo, portanto, não ser representativa do significado real das medias de contagens de Aeromonas spp. obtidas nas amostras dos diferentes tipos de hortaliças. Nesse caso, a variável que melhor reflete o valor real das contagens é a mediana, 
Luma vez um número igual de amostras tem seus valores de contagens abaixo e acima da mesma, podendo ser utilizada, tambem, a média geometrica. Assim, pode-se constatar que para as amostras de agriăo o valor da mediana das contagens de Aeromonas spp. foi de < $1,2 \times 10=$ UFC/g e, portanto, maior em relaça aos obtidos para as amostras de alface e de escarola, que foram de $<102$.

Levando-se em consideraça apenas as amostras positivas para a contagem, isto e, aquelas que se revelaram com a presença de pelo menos 10: UFC/g, a media aritmetica tornase um parâmetro útil para se avaliar a contagem dessas amostras. Nessas condiçoes, a contagem media foi de $3,0 \times 10^{4}$ UFC/g para as amostras de alface, de $1,5 \times 10 s$ para as de agriå e de $7,7 \times 10^{3}$ UFC/g para as de escarola, sendo que a média do total de hortaliças foi de $9,4 \times 10^{4}$ UFC/g. Baseado nesses dados, verifica-se que, tanto a média como o valor maximo das contagens, observado na tabela b, é 1 log maior nas amostras de agriăo em relaçă às de alface e das de alface em relaçăo às de escarola.

A tabela 7 apresenta as amostras de hortalicas analisadas distribuidas segundo os resultados das contagens de UFC/g de Aeromonas spp., em intervalos de classe, q que pode ser, também, visualizado no gráfico 1. Nessa tabela, pode-se observar que a maior parte das amostras de hortalicas analisadas apresentou contagens $<10=$, correspondendo a $68,9 \%$ do total analisado. Fode-se, ainda, depreender da referida tabela, assim como do grafico 1 , que 
a escarola foi a hortaliça que apresentou a maior proporçao de amostras $(86,7 \%)$ localizadas nessa faixa de contagem, seguido da alface $(73,4 \%)$ e, por último, do agriăo $(46,7 \%)$. A faixa de contagem que englobou a segunda maior proporça de amostras de hortalicas $(14,5 \%)$ foi a de 104 a $<10 \%$, sendo de importancia ressaltar que $30 \%$ das amostras de agriă apresentaram contagens compreendidas nessa faixa.

CALLISTER \& AGGEF (1987), nOS Estados Unidos, empregando o metodo da semeadura direta em agar amidoampicilina, obtiveram uma positividade para Aeromonas spp. de $38,1 \%$ em um total de 21 amostras de diferentes hortaliças analisadas.

Na presente investigaçă, verifica-se na tabela 8 que a positividade para essas bacterias revelou-se maior $(47,8 \%)$ do que a obtida por esses autores. Isto poderia ser explicado pelo fato de terem sido utilizados dois processos analiticos, sendo um deles o de semeadura direta em agar amido-ampicilina $e$ o outro, o de plaqueamento após enriquecimento seletivo em caldo tripticase-soja com ampicilina. Se fossem consideradas apenas as amostras positivas para Aeromonas spp. pelo método da semeadura direta, a positividade seria reduzida para $31,1 \%$, uma vez que apenas 28 (e nå 43) do total de 90 amostras analisadas seriam consideradas positivas (tabela 8).

CALLISTER \& AGGEF (1987) obtiveram, para as hortaliças analisadas, contagens de Aeromonas spp. que variaram de $10=$ 
a $2,3 \times 10^{4}$ UFC/g. O menor valor observado nessas contagens equivaleu ao limite inferior de deteçăo dessas bacterias pela metodologia utilizada.

No presente estudo, o valor maximo de contagens observado, mostrou-se muito maior do que o verificado por esses pesquisadores e o agrião contribuiu para as contagens mais altas observadas. Assim, das bo amostras de hortaliças diferentes do agrião, analisadas neste trabalho, apenas uma de alface (amostra 46) apresentou contagem de 2,00100/g e, portanto, acima do valor maximo observado por CALLISTER \& AGGER (1987); a segunda maior contagem, excluindo-se as amostras de agriăo, foi de $2,1 \times 104 / 9$, obtida em uma de escarola (amostra 54), valor este semelhante ao observado por aqueles pesquisadores.

NISHIKAWA \& KISHI (1988), no Japão, analisaram 43 amostras de diferentes alimentos de origem vegetal, incluindo repolhos, cenouras, pepinos, berinjelas, alfaces, ervilhas, cebolas, massas, batatas, rabanetes, arroz, espinafres, "tofu", tomates e saladas de hortaliças, e obtiveram uma positividade de 51,2\% para Aeromonas spp.

FRICKEF \& TOMFSETT (1989), na Inglaterra, examinaram 97 amostras de saladas pre-preparadas e obtiveram positividade de $21,6 \%$.

KNOCHEL \& JEFFESEN (1990), na Dinamarca, analisaram 177 amostras de saladas com maionese contendo, geralmente, cebola ou cebolinha, e obtiveram positividade de 10,2\% para 
Aeromonas spp., com niveis maximos de contagem excedendo 100 UFC/g. A maioria das saladas positivas para essas bacterias continham presunto, mas as amostras de presunto revelaramse, geralmente, negativas.

HUDSON \& de LACY (1991), na Nova Zeländia, estudaram 44 amostras de produtos contendo vegetais, incluindo saladas de repolho picado ("coleslaws") e outras e obtiveram positividade de $9,1 \%$ para Aeromonas spp.; a salada de repolho picado que não continha maionese foi a única positiva para essas bacterias. Segundo esses pesquisadores, a maionese e outros molhos para saladas podem reduzir o pH, impedindo o crescimento ou eliminando as Aeromonas spp. presentes. De acordo com esses autores, isso poderia explicar a baixa positividade para essas bacterias por eles observada nas amostras de alimentos de origem vegetal analisadas, assim como as verificadas por KNOCHEL \& JEFFENSEN (1990) e por FRICKER \& TOMFSETT (1989), alem da possibilidade de muitas dessas saladas terem sido preparadas com alguns vegetais pre-cozidos.

KROVACEK et al. (1992a), na Suecia, analisaram 24 amostras de varios alimentos, incluindo 4 de hortaliças, as quais revelaram-se negativas para Aeromonas spp., em semeadura direta e apos enriquecimento em água peptonada

Em Campinas, Brasil, Leitao \& SIlveIfA (1991) examinaram 15 amostras de alface $e$ obtiveram positividade para Aeromonas spp. de $66,7 \%$, cujas contagens variaram de $2,3 \times 10^{3}$ a $2,4 \times 10^{\circ}$, sendo a media de $7,9 \times 10^{4} \mathrm{UFC} / \mathrm{g}$. 
RODRIGUES (1992), tambem em Campinas, Brasil, analisou um total de 100 amostras de alimentos de origem vegetal e animal obtidas na linha de processamento em um restaurante universitario. Os alimentos de origem vegetal incluiam alface, chicoria, acelga, pepino, cenoura, vagem e outras hortaliças nå especificadas. A positividade para Aeromonas spp. observada nesses alimentos foi de $18 \%$ do total de amostras de alimentos de origem vegetal e de $13 \%$ para os de origem animal.

Na presente investigaçăo, a positividade para Aeromonas spp. foi significativamente maior nas amostras de agriå, quando comparada as de alface e de escarola. Fode-se depreender que o agriå foi a hortaliça que, dentre as analisadas, pode representar maior risco en relaça à saúde humana.

Essa diferença de resultados, também foi observada por OLIVEIRA \& GERMANO (1992) em um estudo envolvendo a pesquisa de enteroparasitas em diferentes tipos de hortaliças, comercializadas na regiăo metropolitana de Săo fialo. Nesse estudo foram analisados os mesmos tipos de hortalicas empregados no presente estudo, isto e, alface lisa, agriaro e escarola, além de alface crespa. o tipo de hortaliça que apresentou maior contaminacão com enteroparasitas tambem foi - agriå. Os autores atribuem essas diferenças de contaminaça as variadas condiçoses sanitarias do ambiente onde essas hortaliças são cultivadas. Assim, o cultivo de 
agriå ocorre normalmente em brejos ou seja, em terrenos permanentemente úmidos, a que, segundo esses pesquisadores, poderia justificar as frequencias superiores de helmintos nesse tipo de hortalica, uma vez que a sobrevivencia de seus ovos é mais propicia nesse ambiente.

Essa explicaça sugerida por OLIVEIRA \& GERMANO (1992) poderia tambem justificar a maior positividade para Aeromonas spp. observada nas amostras de agriaro, quando comparada ès de outras hortalicas analisadas neste estudo, uma vez que diversos autores verificaram a presenca dessas bacterias em diversos tipos de aguas (HAZEN et al., 1978; FIPFEY \& CABELLI, 1979; BUFKE et al., 1984c, 1984d, NEVES et a1. , 1990; LEITFO \& SILVEIFA, 1991).

A tabela 8 mostra o numero e a percentagem de amostras positivas para Aeromonas spp. por uma ou por ambas as metodologias utilizadas. Analisando-se os dados dessa tabela, verifica-se que um certo número de amostras de hortalicas revelaram-se positivas para essas bacterias, apenas por uma das metodologias de isolamento utilizadas. Esse fato é facilmente explicavel quando a presença desses microrganismos é detectada pelo método de presença/ausencia, envolvendo o enriquecimento seletivo antes do plaqueamento e não pela semeadura direta em agar seletivo, como ocorreu com $5(16,7 \%)$ amostras de cada tipo de hortalica. Nesse caso, as Aeromonas spp. podem estar presentes em número inferior ao do limite minimo de deteçăo dessas bacterias pela semeadura 
direta (102) ou, ainda, elas podem estar presentes em números maiores, porem injuriadas. Neste caso, 0 enriquecimento podera favorecer a sua recuperacăo e multiplicaç̃o e, consequentemente, a sua deteç̣a.

Entretanto, o fato de $4(13,3 \%)$ amostras de alface e de agriăo terem se revelado positivas para Aeromonas spp. apenas pela metodologia da semeadura direta em agar amidoampicilina e negativas pelo metodo empregando o enriquecimento previo, năo parece ser tão facilmente explicavel. Uma possibilidade é a de que o inoculo transferido da cultura em caldo de enriquecimento para o ágar seletivo possa não conter Aeromonas spp. embora tenha havido crescimento dessas bactérias. O referido inoculo pode conter Aeromonas spp., porem misturadas com outros microrganismos, tambem resistentes à ampicilina, que podem estar presentes em números elevados. Assim, a possibilidade do inbculo em questäo conter Aeromonas spp. năo e total, uma vez que essa passagem é feita atraves de uma única alçada. Dutra explicaçăo possivel é a da competitividade das Aeromonas spp. com outros microrganismos que podem estar presentes no caldo de enriquecimento, provenientes das hortalicas analisadas.

A esse respeito, FALUMBO \& BUCHANAN (1988) verificaram, em carne suína moida mantida a 50C, que a $A$. hydrophila atingia números mais elevados quando na ausencia da microbiota normal e KIFOV et al. (1990) observaram que uma 
cepa de $A$. sobria isolada de frango não demonstrou crescimento significativo a temperatura de refrigeraça em competiç⿰丿丶 com uma cepa de Pseudomonas fragi.

Nesta investigaça, embora a temperatura utilizada no enriquecimento tenha sido a de 280C, a seleçá de outros microrganismos em detrimento das Aeromonas spp. poderia tambem ter ocorrido nas amostras de hortaliças positivas pelo metodo da semeadura direta e negativas no de presenca/ausencia.

Utilizando 0 teste de duas proporçoses $(z=2+\ldots=1,96)$ (BERQUO et al.. 1981), verificou-se que para a alface ( $z=$ $1,498)$ e 0 agriăo $(z=0,066)$ nå houve diferença significativa dos resultados obtidos com relacão a metodologia aplicada. For outro lado, no caso da escarola ( = 3,580$)$, houve diferença significativa entre os resultados obtidos com as metodologia lutilizadas, o que poderia ser explicado pelo valor 0 (zero) do número de amostras com resultado negativo na contagem e positivo no teste de presença/ausencia.

De qualquer modo, na determinaçăo de Aeromonas do grupo A. hydrophila em hortalicas, e recomendavel utilizar a semeadura direta em agar amido-ampicilina e apos o enriquecimento, simultaneamente, uma vez que diversas amostras analisadas neste trabalho revelaram a presença dessas bacterias por apenas uma das metodologias. 
OKREND et al. (1987) fizeram um estudo comparativo entre diversas metodologias de isolamento de Aeromonas spp. a partir de amostras de carnes de aves, bovinas e suinas. Os autores concluiram que a utilizaçăo de meios de enriquecimento facilitava a recuperaça dessas bacterias e que isso ocorria, principalmente, no caso de amostras contendo Aeromonas spp. injuriadas pelo congelamento ou quando em números baixos ( $(102)$.

MAJEED et al. (1989) analisaram 54 amostras de carne e miĺdos de cordeiro e obtiveram positividades de $26 \%$ e de $59 \%$, atraves da semeadura direta em agar amido-ampicilina e apos enriquecimento em agua peptonada alcalina a $0,1 \%$, respectivamente. Concluiram que o enriquecimento facilitou bastante a recuperaça de Aeromonas spp.

GHENGHESH (1989) analisou amostras de fezes atraves da semeadura direta em agar sangue de carneiro adicionado de ampicilina $(1 \mathrm{mg} / 100 \mathrm{~mL})$ e apos enriquecimento em água peptonada alcalina (pH 9). Observou que o enriquecimento propiciou um aumento significativo da taxa de isolamento do total de Aeromonas spp. e, em particular, de A. caviae.

HUDSON \& de LACY (1991) nåo obtiveram positividade para Aeromonas spp. em produtos de origem vegetal e saladas, através da inoculaçăo direta em agar amido-ampicilina, seguida de incubaça a $280 \mathrm{C}$ por ate 48 horas, mas apenas após o pre-enriquecimento em agua peptonada alcalina a $0,1 \%$. 
A tabela 9 mostra o número de cepas isoladas e o número e percentagem de cepas confirmadas como sendo de Aeromonas do grupo A. hyorophila em cada grupo de 10 amostras de hortalicas analisadas. No total, foram isoladas do agar amido-ampicilina 187 cepas que se revelaram com comportamento caracteristico no agar triplice-açucar-ferro e com reaça positiva nas provas de oxidase e catalase, sendo que 143 (76,5\%) foram confirmadas como sendo Aeromonas spp. Entretanto, se as cepas provenientes das 10 primeiras amostras forem excluidas desse calculo, a percentagem de cepas confirmadas passa de 76,5\% para $83,5 \%$. Esta diferença ocorre devido à baixa percentagem de cepas confirmadas nas 10 primeiras amostras analisadas $(26,1 \%)$. Esse fato pode ser atribuldo a dificuldades ocorridas no inicio da pesquisa, com relaç⿰丿 à caracterizaçăo visual do aspecto das colonias suspeitas desenvolvidas no agar amido-ampicilina.

PALUMBO et al. (1985a), CALLISTER \& AGGEF (1987) e MAJEED et al. (1989), utilizando o agar amido-ampicilina, isolaram 65, 61 e 73 cepas, a partir de amostras de alimentos de origem animal, vegetal e de carne e milidos de cordeiro, respectivamente. Obtiveram confirmçăo de Aeromonas spp. em 80\% , $74 \%$ e 100\% das cepas isoladas, respectivamente.

LEITFO \& SILVEIFA (1991), tambem utilizando o agar amido-ampicilina como meio de isolamento de Aeromonaz spp.. confirmaram $79,4 \%$ de um total de 136 cepas isoladas de agua 
do mar, frutos do mar, água de rios, peixes de agua doce e hortaliças. Com relaçao a 54 cepas isoladas das amostras de agua de rios, peixes de agua doce e hortalicas, esses pesquisadores confirmaram 44 (81,5\%) como sendo Aeromonas spp.

Com relạ̧a as diferentes especies de Aeromonas
isoladas das amostras de hortalicas analisadas, do total de
145 cepas confirmadas como sendo do genero Aeromonas, 138
$(96,5 \%)$ foram identificadas como sendo $A$. caviae, $4(2,8 \%)$ como $A$. hyorophila e $1(0,7 \%)$, embora tenha se revelado com caracteristicas de Aeromonas spp., é referida como Aeromonas atipica, tendo em vista o seu comportamento bioquímico.

$\mathrm{Na}$ tabela 10, pode-se constatar que, das 43 amostras de hortalicas positivas para Aeromonas spp., $\$ 9$ (90,7\%) revelaram a presença exclusiva de $A$. caviae, $1(2,3 \%)$, de A. caviae e Aeromonas atipica simultaneamente e $3(7,0 \%)$ se mostraram com a presença exclusiva de A. hyorophila. Com relaçă as diferentes hortaliças analisadas, das 13 (30,2\% do total de amostras positivas) amostras de alface positivas para Aeromonas spp., $11(84,6 \%)$ revelaram a presença exclusiva de A. caviae e $2(15,4 \%)$, de A. hyorophila; das 21 (48,8\% do total de positivas) amostras de agriăo positivas, $19(90,4 \%)$ revelaram a presenca exclusiva de $A$. caviae, 1 $(4,8 \%)$, de A. caviae e Aeromonas atipica, simultaneamente, e $1(4,8 \%)$ foi positiva somente para $A$. hydrophila e as 9 (20,9\% do total de positivas) amostras de escarola revelaram a presença exclusiva de $A$, caviae (tabela 10). 
Com base nos dados descritos, pode-se constatar que a A. caviae foi a especie significativamente mais isolada das hortaliças analisadas, sendo que a $A$. hydrophila estava presente apenas em algumas delas. Nå se obteve o isolamento de $A$. sobria.

CALLISTEF \& AGGEF (1987), nos Estados Unidos, também nă isolaram $A$. sobria a partir de amostras de hortaliças. Esses pesquisadores, em 45 cepas de Aeromonas móveis, confirmaram 29 como sendo de A. hydrophila e 16, de A. caviae, respectivamente.

NISHIKAWA \& KISHI (1988), no Japaั, nå isolaram cepas de $A$. sobria e observaram a predominancia de $A$. caviae em amostras de alimentos de origem vegetal, assim como ocorreu na presente investigaça. De um total de 27 cepas confirmadas como sendo Aeromonas spp., 17 (6.3\%) e 10 (37\%) eram de A. caviae e A. hyorophila, respectivamente. De um total de 15 tipos de alimentos de origem vegetal, obtiveram o isolamento de $A$. caviae de 11 e A. hyorophila de 5. Esses pesquisadores sugeriram uma relaça entre a presença predominante de $A$. caviae nas fezes e o consumo desses alimentos, no Japão.

GHENGHESH (1989), em São Faulo, Brasil, analisou fezes de 100 crianças e 69 adultos com diarréia e 100 crianças e 17 adultos assintomaticos (controle) e verificou que, de forma geral, A. caviae foi a especie mais detectada. Esse autor isolou $40(59,7 \%)$ cepas de $A$. caviae, $15(22,4 \%)$ de 
A. sobria e $12(17,9 \%)$ de A. hyorophila de um total de $47 x$ cepas confirmadas como Aeromonas spp.

NEVES et al. (1990), no Rio de Janeiro, Erasil, analisando 50 amostras de equa salgada e doce, tambem observaram uma predominancia de A. caviae. Assim, das 100 cepas por eles isoladas, bo eram de $A$. caviae, enquanto que 14 eram de $A$. veronit e apenas 1 era de $A$. hydrophila e 1 de A. sobria. Os autores verificaram, tambem, qule a presença de $X$ 24 cepas que eles classificaram como Aeromonas spp. por não terem conseguido distinguir em especies atraves dos testes bioquimicos por eles utilizados.

Leitao \& SILVEIRA (1991), em 45 amostras de agua doce, peixes de agua doce e alface, obtiveram 44 cepas de Aeromonas spp. Destas, $19(4.3,2 \%)$ foram de A. hydrophila, 17 $(38,6 \%)$ de A. caviae, $1(2,3 \%)$ de A. sobria e $7(15,9 \%)$ de Ae romonas spp. imóveis.

RODFIGUES (1992), isolou 28 cepas de Aeromonas spp. a partir de alimentos de origem vegetal, sendo $15(53,6 \%)$ de A. hydrophila, $11(39,3 \%)$ de A. caviae e $2(7,1 \%)$ de A. sobria. Apesar desse pesquisador ter isolado A. caviae de hortaliças em menor proporţao do que $A$, hyorophila, ao contrario do que ocorreu na presente investigaça, ele concluiu que $A$. caviae foi isolada significativamente mais de amostras de hortalicas e A. sobria, de carnes.

HAVELAAR et al. (1992), na Holanda, observaram que a A. caviae era a especie mais frequentemente isolada tanto de fezes de pacientes com diarreia aquosa, sanguinolenta ou 
fezes de pacientes com diarreia aquosa, sanguinolenta ou mucosa como de água potavel. Esses pesquisadores isolaram $181(46,8 \%)$ cepas de $A$, caviae, $126(32,5 \%)$ de A, hydrophila e $80(20,7 \%)$ de $A$. sobria de um total de 387 cepas.

A tabela 11 mostra o número e a percentagem de cepas segundo a positividade frente aos diferentes testes bioquímicos e microscopicos utilizados na identificaçă das 4 cepas de $A$. hydrophila e das 138 cepas de $A$. caviae isoladas. Deve ser ressaltado que o número de cepas de A. hydrophila e muito reduzido para que se possa fazer uma anklise do comportamento destas bacterias frente a alguns testes bioquimicos, cujos resultados foram diferentes dos esperados para cepas de $A$. hydrophila.

A cepa denominada Aeromonas atipica demonstrou positividade para a prova de descarboxilaça da ornitina, o que seria esperado para a $A$. veronii (HICKMAN-BRENNER et al., 1987; CAFINAHAN et al., 1991). Entretanto, essa cepa foi positiva na prova de ltilizaçăo da arginina e negativa na da lisina, o contrario do esperado para a A. veronit. A cepa em queståo apresentou-se, ainda, positiva nas provas de utilizaçăo da arabinose e esculina e negativa nas provas de produça de gas a partir da glicose e de produçă do fator semelhante ao CAMF em aerobiose, tambem contrario do esperado para A. veronii (CARNAHAN, 1991). A Aeromonas at1pica, com exceça das provas de utilizaçă de aminoacidos e da prova de voges-Proskauer, apresentou as mesmas caracteristicas de $A$, caviae. 
Embora a referida cepa tenha sido a Ĺnica denominada de atipica, outras apresentaram algumas caracteristicas contrárias ao esperado, apesar de terem sido consideradas como pertencentes a uma determinada especie. Ao mesmo tempo, 2 cepas que apresentaram caracteristicas de $A$, caviae, inclusive sendo moveis e crescendo a 370C, produziam pigmentaça marrom com apenas 24 horas de incubaçå em agar tripticase-soja, caracteristica esta associada a A. salmonicida. Ambas foram classificadas como A. caviae. Conforme pode ser constatado na tabela 11, dentre as cepas de $A$. caviae isoladas, 4 eram indol negativas, 2 eram salicina negativas (positividades de $97,1 \%$ e de $98,6 \%$, respectivamente) e $2(1,4 \%)$ eram positivas para a prova de Voges-Froskauer, contrário do esperado para A. caviae. Das 4 cepas de $A$. hydrophila isoladas, 1 revelou-se negativa na prova de Voges-Proskauer (positividade de $75 \%$ ), sendo que essa prova é considerada positiva para $A$. hyorophila.

A deteção de flagelo polar em meio sólido foi considerada negativa para 4 cepas de $A$. caviae apos 5 tentativas. No entanto, năo se pode afirmar que as cepas em questå nสัo produzam flagelos, mas apenas que nå foram detectados.

Os resultados na prova de utilizaçăo de arginina foram multo variáveis para as cepas de $A$. caviae isoladas, sendo que essa especie é considerada geralmente positiva (tabela 1). Assim, conforme pode ser observado na tabela 11, do total de 138 cepas de $A$, caviae isoladas, apenas 43 
revelaram-se positivas para a utilizaçăo desse amino-acido. Com relaço à utilizaçăo da lisina, com exceçăo de uma cepa, todas se revelaram negativas no teste. For outro lado, as cepas de $A$. hydrophila isoladas revelaram-se positivas para a prova da utilizacão de arginina e negativas para a da ornitina, conforme o esperado (tabela 1), sendo que apenas 1 cepa revelou-se positiva no teste de utilização da lisina.

KUIJPER et al. (1989), em 124 cepas de A. caviae isoladas de fezes humanas, verificaram uma positividade de $97 \%$ na prova do indol e de $96 \%$ na de ltilizaça da salicina: em 31 cepas de A. hydrophila, tambem isoladas de fezes humanas, observaram luma positividade de $65 \%$ na prova de Voges-Froskalier.

GHENGHESH (1989) observou luma positividade de $96,7 \%$ na prova do indol e de $3,3 \%$ na prova de Voges-Froskauer, em um total de 30 cepas de $A$. caviae isoladas de fezes humanas. Em 8 cepas de $A$. hyorophila por ele isoladas, tambem de fezes humanas, esse pesquisador observou uma positividade de $87,5 \%$ na prova de Voges-Froskauer e de $87 \%$ de utilização da 1 isina.

ALTWEGG et al. (1990) em 78 cepas de A. caviae, na maioria isoladas de fezes humanas, obtiveram uma positividade de $90 \%$ para a prova do indol, de $91 \%$ e $86 \%$ no teste de utilizaçă de salicina nos sistemas "AFI 50E" e "AFI ATB S2GN", respectivamente, de $8 \%$ na prova de VogesFroskauer e de $85 \%$ no teste de utilizaçăo de arginina no sistema "AFI 2OE". Esses autores verificaram, tambem, que 28 
cepas de A. hydrophila, na maioria isoladas de fezes humanas, revelaram-se positivas na prova de Voges-firoskauer. ALABI \& ODUGBEMI (1790) relataram positividades de $75 \%, 22 \%$ e $75 \%$ frente as provas de produça de indol $e d a$ utilizaço ornitina e da lisina, respectivamente, num total de 55 cepas de Aeromonas spp isoladas de fezes humanas.

RODFIGUES (1992) verificou que de 13 cepas de $A$. caviae isoladas de alimentos de origem animal e vegetal, $84 \%, 15 \%$ e de 8\% eram positivas nas provas de utilizaçă de salicina, de Voges-Proskauer e a utilizacăo de lisina, respectivamente. Em 25 cepas de A. hydrophila isoladas dos mesmos tipos de alimentos, o autor constatou que $84 \%$ eram positivas na prova de Voges-Proskauer e de $76 \%$ na de utilizaçă de lisina.

Dentre as publicaçBes existentes, dependendo dos autores, a A. caviae é considerada como năo patogenica e a A. hydrophila e a A. sobria săo tidas como potencialmente patogenicas (DAILY et al.; 1981; GFACEY et al.; 1982; JANDA et al., 1983; JANDA et al., 1984; BUCHANAN, 1984; BUCHANAN \& FALUMBO, 1985; WATSON et al., 1985). Entretanto, tem surgido publicaçós sobre a patogenicidade de cepas de A. caviae (TURNBULL et al., 1984; MOYEFi, 1987; CARRELLO et a 1., 1988; NAMDAFI \& EOTTONE, 1990a, 19906, 1991).

Diante do exposto, os resultados obtidos nesta investigạ̧a indicam que hortaliças, particularmente o agriă, podem representar risco aos consumidores, tendo em 


\begin{abstract}
vista o fato das verduras analisadas serem consumidas cruas em largea escala, em nosso meio.

E recomendavel a adoça de medidas de higiene apropriadas, a fim de que se possa evitar a ingestá direta de hortaliças contaminadas com Aeromonas spp., cuja contagem nesses alimentos pode aumentar durante a sua manutença sob refrigeraço (CALLISTEF \& AGGER, 1987). Deve-se, atraves de medidas de higiene, evitar a contaminaçăo cruzada com outros tipos de alimentos, particularmente aqueles previamente submetidos a tratamento térmico e, portanto, isentos ou com números baixos de outros microrganismos.
\end{abstract}


Tabela 2 Resultados do teste presenca/ausencia e da contagem de Aeromonas do grupo A. hyorophila e especies isoladas, em amostras de hortaliças comercializadas na cidade de São Faulo, 1993.

\begin{tabular}{|c|c|c|c|c|c|}
\hline \multicolumn{2}{|c|}{ AMOSTRA* } & \multirow{2}{*}{\multicolumn{2}{|c|}{$\begin{array}{l}\text { PRESENÇA/AUSENCIA } \\
\text { em } 1 \mathrm{a}\end{array}$}} & \multirow{2}{*}{$\begin{array}{l}\text { CONTAGEM } \\
\text { UFC/Q }\end{array}$} & \multirow{2}{*}{$\begin{array}{l}\text { ESPECIES } \\
\text { ISOLADAS }\end{array}$} \\
\hline No & TIPO & & & & \\
\hline 1 & alface 1 & & ausencia & 100 & - \\
\hline 2 & agrião 1 & & ausencia & $<100$ & - \\
\hline 3 & escarola & 1 & ausencia & $<100$ & - \\
\hline 4 & alface 2 & & presenca & $<100$ & A. hydrophila \\
\hline 5 & agriสัด 2 & & ausencia & $<100$ & - \\
\hline 6 & escarola & 2 & ausencia & $<100$ & - \\
\hline 7 & alface 3 & & ausencia & $<100$ & - \\
\hline 8 & agriสั 3 & & ausencia & $<100$ & - \\
\hline 9 & escarola & $\Xi$ & ausencia & $<100$ & - \\
\hline 10 & alface 4 & & presenca & $1,0 \times 10=$ & A. caviae \\
\hline 11 & agrião 4 & & presença & $2,4 \times 10^{4}$ & $\begin{array}{l}\text { A. caviae e } \\
\text { romonas sop. }\end{array}$ \\
\hline 12 & escarola & 4 & presenca & $2,0 \times 10=$ & $\begin{array}{r}\text { A. caviae } \\
\text { A. cavial }\end{array}$ \\
\hline 13 & alface 5 & & ausencia & $<100$ & - \\
\hline 14 & agriสัด 5 & & ausencia & $<100$ & - \\
\hline 15 & escarola & 5 & ausencia & $<100$ & - \\
\hline 16 & alface 6 & & ausencia & $<100$ & - \\
\hline 17 & agriสัด 6 & & ausencia & $1,0 \times 10^{4}$ & A. caviae \\
\hline 18 & escarola & 6 & ausencia & $<100$ & - \\
\hline 19 & alface 7 & & ausencia & $<100$ & - \\
\hline 20 & agriสั 7 & & ausencia & $1,4 \times 10^{5}$ & A. hydrophila \\
\hline 21 & escarola & 7 & ausència & $<100$ & - \\
\hline 22 & alface 8 & & ausencia & $<100$ & - \\
\hline 23 & agriăo 8 & & presença & $2,0 \times 10^{4}$ & A. caviae \\
\hline 24 & escarola & 8 & ausencia & 100 & - \\
\hline 25 & alface 9 & & ausencia & $<100$ & - \\
\hline 26 & agriสัo 9 & & ausencia & $2,0 \times 10^{0}$ & A. caviae \\
\hline 27 & escarola & 9 & ausencia & $<100$ & - \\
\hline 28 & alface 10 & & ausencia & $1,0 \times 10^{4}$ & A. caviae \\
\hline 29 & agriสั 10 & & ausencia & 100 & - \\
\hline 30 & escarola & 10 & ausencia & $<100$ & - \\
\hline
\end{tabular}

UFC/g unidades formadoras de colonias por g

* Prineira coluna - enuseraço das anostras de hortalicas analisadas. de hortalisa.

Os núneros correspondentes d segunda coluna referen-se à nuneraça das anostras de cada tipo

* * Cepa atipica que nao foi classificada cono pertencente a una deterninada especie, pois, eabora nato tenha apresentado as características de $A$, veronii, revelou-se positiva para a utilizaço da ornitina. 
Tabela 2 Fiesultados do teste presenca/ausencia $e$ da (conti- contagem de Aeromonas do grupo $A$, hydrophila nuaça) e especies isoladas, em amostras de hortalicas comercializadas na cidade de Săo Faulo, 1995.

\begin{tabular}{|c|c|c|c|c|}
\hline \multicolumn{2}{|c|}{ AMOSTRA* } & \multirow{2}{*}{$\begin{array}{l}\text { PRESENCA/AUSENCIA } \\
\text { em } 1 \text { a }\end{array}$} & \multirow{2}{*}{$\begin{array}{l}\text { CONTAGEM } \\
\text { UFC/q }\end{array}$} & \multirow{2}{*}{$\begin{array}{l}\text { ESPECIES } \\
\text { ISOLADAS }\end{array}$} \\
\hline No & TIPD & & & \\
\hline 31 & alface 11 & presenca & $<100$ & A. caviae \\
\hline 32 & agriสัo 11 & presença & 100 & A. caviae \\
\hline 33 & escarola 11 & ausencia & 100 & - \\
\hline 34 & alface 12 & ausencia & $<100$ & - \\
\hline 35 & agriสัด 12 & presença & $\therefore 100$ & caviae \\
\hline 36 & escarola 12 & ausencia & $<100$ & - \\
\hline 37 & alface 13 & ausencia & $<100$ & - \\
\hline 38 & agriสั 13 & presença & $1,2 \times 10^{4}$ & A. caviae \\
\hline 39 & escarola 13 & ausencia & $<100$ & - \\
\hline 40 & alface 14 & ausencia & $<100$ & - \\
\hline 41 & agriสั 14 & presença & $1,2 \times 100$ & A. caviae \\
\hline 42 & escarola 14 & ausencia & $<100$ & - \\
\hline 4.3 & alface 15 & ausencia & $<100$ & - \\
\hline 44 & agriสั0 15 & presenca & $4,4 \times 10^{4}$ & A. caviae \\
\hline 45 & escarola 15 & ausencia & $<100$ & - \\
\hline 46 & alface 16 & presença & $2,0 \times 100$ & A. caviae \\
\hline 47 & agrião 16 & presença & $<100$ & A. caviae \\
\hline 48 & escarola 16 & ausencia & 100 & - \\
\hline 49 & alface 17 & ausencia & 100 & - \\
\hline 50 & agriส̃ 17 & ausencia & 100 & - \\
\hline 51 & escarola 17 & presença & 100 & A. caviae \\
\hline 52 & alface 18 & ausencia & $1,0 \times 10^{3}$ & A. caviae \\
\hline 53 & agriสัo 18 & presença & $4,8 \times 10^{4}$ & A. caviae \\
\hline 54 & escarola 18 & presença & $2,1 \times 10^{4}$ & A. caviae \\
\hline 55 & alface 19 & presenca & $2,0 \times 10=$ & A. caviae \\
\hline 56 & agriสัo 19 & ausencia & $<100$ & - \\
\hline 57 & escarola 19 & presenca & $<100$ & A. caviae \\
\hline 58 & alface 20 & ausencia & $<100$ & - \\
\hline 59 & agrião 20 & presenca & $1,0 \times 10^{3}$ & A. caviae \\
\hline 60 & escarola 20 & ausencia & $<100$ & - \\
\hline
\end{tabular}

UFC/g unidades formadoras de colonias por g

Prineira coluna - enunerasto das anostras de hortaliças analisadas. de hortalişa.

Os nuneros correspondentes à segunda coluna referen-se à nuneraçto das anostras de cada tipo 
Tabela 2 Fiesultados do teste presenca/ausencia e da (conti- contagem de Aeromonas do grupo A. hydrophila nuaçă e especies isoladas, em amostras de hortaliças comercializadas na cidade de Să Faulo, 1995.

\begin{tabular}{|c|c|c|c|c|}
\hline \multicolumn{2}{|c|}{ AMOSTRA* } & \multirow{2}{*}{$\begin{array}{l}\text { PRESENÇA/AUSENCIA } \\
\text { em } 1 \mathrm{q}\end{array}$} & \multirow{2}{*}{$\begin{array}{l}\text { CONTAGEM } \\
\text { UFC/Q }\end{array}$} & \multirow{2}{*}{$\begin{array}{l}\text { ESPECIES } \\
\text { ISOLADAS }\end{array}$} \\
\hline No & TIPO & & & \\
\hline 61 & alface 21 & ausencia & 100 & - \\
\hline 62 & agriสั 21 & presenca & $2,8 \times 10^{0}$ & A. caviae \\
\hline 6.5 & escarola 21 & presenca & $9,6 \times 10=$ & caviae \\
\hline 64 & alface 22 & ausencia & $3,2 \times 10=$ & caviae \\
\hline 65 & agriสo 22 & presenca & $5,0 \times 10=$ & caviae \\
\hline 66 & escarola 22 & ausencia & $<100$ & - \\
\hline 67 & alface 23 & ausencia & $<100$ & - \\
\hline 68 & agriă 23 & aLıSEncia & 100 & - \\
\hline 69 & escarola 23 & ausencia & $<100$ & - \\
\hline 70 & alface 24 & ausencia & $1,0 \times 10^{4}$ & A. hyorophila \\
\hline 71 & agriăo 24 & ausencia & $5,2 \times 10^{4}$ & A. caviae \\
\hline 72 & escarola 24 & presenca & 100 & caviae \\
\hline 73 & alface 25 & ausencia & 100 & - \\
\hline 74 & agriสั 25 & presenca & $2,8 \times 10=$ & A. caviae \\
\hline 75 & escarola 25 & ausencia & $<100$ & - \\
\hline 76 & alface 26 & ausencia & 100 & - \\
\hline 77 & agriสัธ 26 & ausencia & 100 & - \\
\hline 78 & escarola 26 & presença & 100 & A. caviae \\
\hline 79 & alface 27 & presenca & $<100$ & caviae \\
\hline 80 & agriåo 27 & presenca & $1,0 \times 10^{4}$ & A. caviae \\
\hline 81 & escarola 27 & presenca & $<100$ & A. caviae \\
\hline 82 & alface 28 & presenca & $<100$ & A. caviae \\
\hline 83 & agriสัด 28 & presença & 100 & caviae \\
\hline 84 & escarola 28 & presenca & $1,4 \times 10=$ & caviae \\
\hline 85 & alface 29 & presenca & $<100$ & A. caviae \\
\hline 86 & agriāo 29 & presenca & $<100$ & A. caviae \\
\hline 87 & escarola 29 & ausencia & $\leqslant 100$ & - \\
\hline 88 & alface 30 & presenca & $1,1 \times 10^{4}$ & A. caviae \\
\hline 89 & agriaัo 30 & presença & $4,8 \times 10^{4}$ & A. caviae \\
\hline 90 & escarola 30 & ausencia & $<100$ & - \\
\hline
\end{tabular}

UFC/g Lunidades formadoras de colonias por g

Prineira coluna - enunerasto das asostras de hortalicas analisadas.

Os núneros correspondentes d segunda coluna referes-se d nuneracto das anostras de cada tipo de hortalişa. 
Tabela 3 Fiesultados do teste presenca/ausencia $e$ da contagem de Aeromonas do grupo A. hyorophila e especies isoladas, em amostras de alface analisadas, São Faulo, 1993.

\begin{tabular}{|c|c|c|c|c|c|}
\hline $\begin{array}{l}\text { AMOSTRA } \\
\text { NO }\end{array}$ & $\begin{array}{c}\text { ALFACE } \\
\text { NO } \\
\end{array}$ & $\begin{array}{l}\text { PRESENÇA/AUSENCIA } \\
\text { em } 1 \text { q }\end{array}$ & $\begin{array}{l}\text { CONTAGEM } \\
\text { UFC/q }\end{array}$ & & $\begin{array}{l}\text { ESPECIES } \\
\text { ISOLADAS }\end{array}$ \\
\hline 1 & 1 & ausencia & $<100$ & & - \\
\hline 4 & 2 & presenca & $<100$ & A. & hydrophila \\
\hline 7 & 3 & ausencia & $<100$ & & - \\
\hline 10 & 4 & presenca & $1,0 \times 10=$ & & A. caviae \\
\hline 13 & 5 & ausencia & $<100$ & & - \\
\hline 16 & 6 & ausencia & $<100$ & & - \\
\hline 19 & 7 & ausencia & $<100$ & & - \\
\hline 22 & 8 & ausencia & $<100$ & & - \\
\hline 25 & 9 & ausencia & $<100$ & & - \\
\hline 28 & 10 & ausencia & $1,0 \times 10^{4}$ & & A. caviae \\
\hline 31 & 11 & presenca & $<100$ & & A. caviae \\
\hline 34 & 12 & ausencia & $<100$ & & - \\
\hline 37 & 13 & ausencia & $<100$ & & - \\
\hline 40 & 14 & ausencia & $<100$ & & - \\
\hline 4.3 & 15 & ausencia & $<100$ & & - \\
\hline 46 & 16 & presenca & $2,0 \times 100$ & & A. caviae \\
\hline 49 & 17 & ausencia & $<100$ & & - \\
\hline 52 & 18 & ausencia & $1,0 \times 10^{=}$ & & A. caviae \\
\hline 55 & 19 & presenca & $2,0 \times 10=$ & & A. caviae \\
\hline 58 & 20 & ausencia & $<100$ & & - \\
\hline 61 & 21 & ausencia & $<100$ & & - \\
\hline 64 & 22 & ausencia & $3,2 \times 10^{3}$ & & A. caviae \\
\hline 67 & 23 & ausencia & 100 & & - \\
\hline 70 & 24 & ausencia & $1,0 \times 10^{4}$ & A. & hyorophila \\
\hline 73 & 25 & ausencia & $<100$ & & - \\
\hline 76 & 26 & ausencia & $<100$ & & - \\
\hline 79 & 27 & presenca & $<100$ & & A. caviae \\
\hline 82 & 28 & presenca & 100 & & A. caviae \\
\hline 85 & 29 & presenca & 6100 & & A. caviae \\
\hline 88 & 30 & presenca & $1,1 \times 10^{4}$ & & A. caviae \\
\hline
\end{tabular}


Tabela 4 Fiesultados do teste presenca/ausencia e da contagem de Aeromonas do grupo A. hydrophila E especies isoladas, em amostras de agriă analisadas, Să Faulo, 1993.

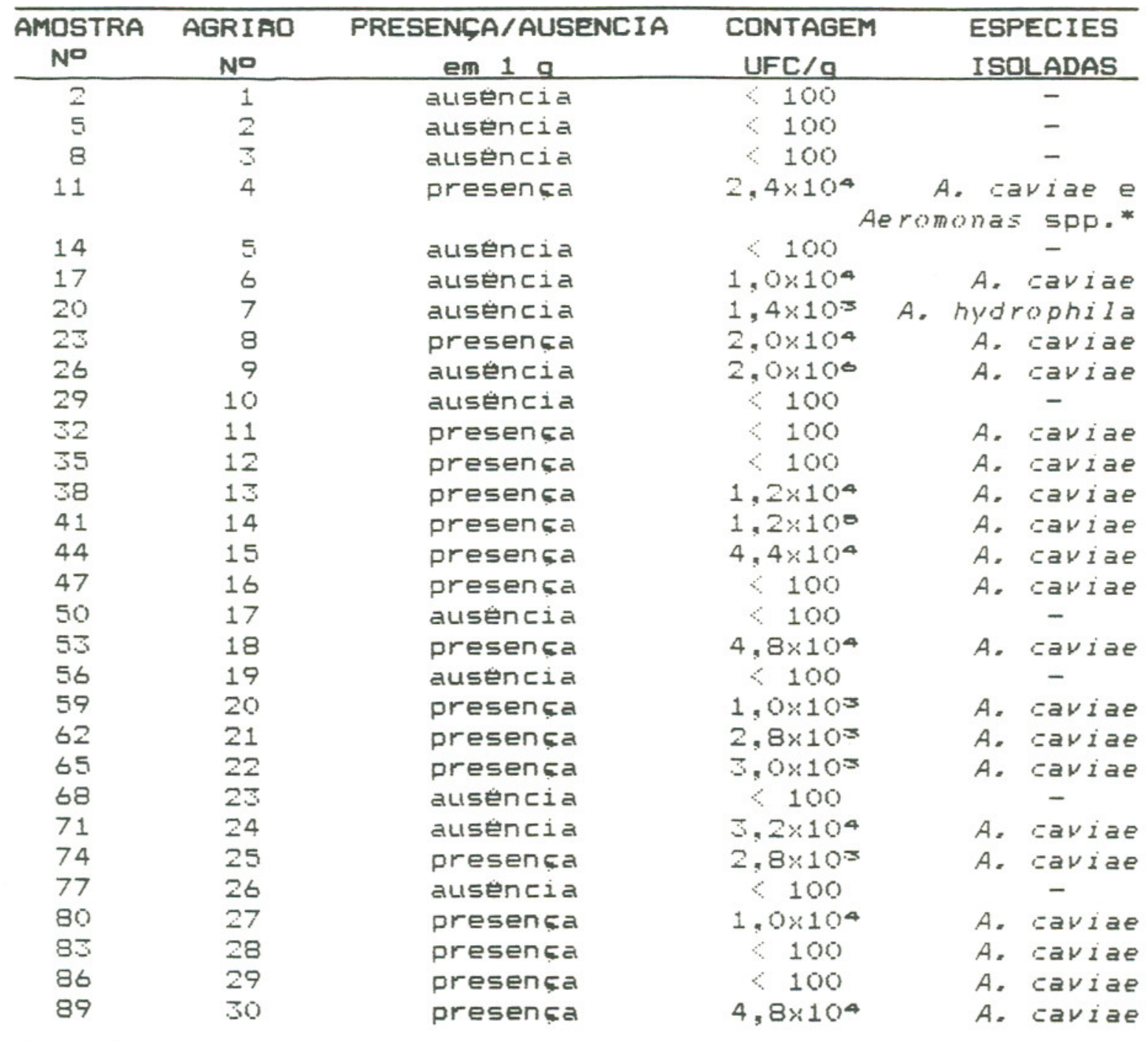

UFC/g Linidades formadoras de colonias por grama

* Cepa atípica que noto foi classificada cono pertencente a una deterninada especie, pois, enbora nato tenha apresentado as características de $A$. veronii, revelou-se positiva para a utilizaço de ornitina. 
Tabela 5 Resultados do teste presenca/ausencia e da contagem de Aeromonas do grupo A. hydrophila E especies isoladas, em amostras de escarola analisadas, Săo Faulo, 1993.

\begin{tabular}{|c|c|c|c|c|}
\hline $\begin{array}{l}\text { AMOSTRA } \\
\text { NO }\end{array}$ & $\begin{array}{l}\text { ESCAROLA } \\
\text { NO }\end{array}$ & $\begin{array}{c}\text { PRESENCSA/AUSENCIA } \\
\text { em } 10\end{array}$ & $\begin{array}{c}\text { CONTAGEM } \\
\text { UFC/O }\end{array}$ & $\begin{array}{l}\text { ESPECIES } \\
\text { ISOLADAS }\end{array}$ \\
\hline 3 & 1 & ausencia & $<100$ & - \\
\hline 6 & 2 & ausencia & $<100$ & - \\
\hline 9 & 3 & ausencia & $<100$ & - \\
\hline 12 & 4 & presença & $2,0 \times 10=$ & A. caviae \\
\hline 15 & 5 & ausencia & 100 & - \\
\hline 18 & 6 & ausencia & $<100$ & - \\
\hline 21 & 7 & ausencia & $<100$ & - \\
\hline 24 & 8 & ausencia & $<100$ & - \\
\hline 27 & 9 & ausencia & $<100$ & - \\
\hline 30 & 10 & ausencia & $<100$ & - \\
\hline 53 & 11 & ausencia & 100 & - \\
\hline 36 & 12 & ausencia & $<100$ & - \\
\hline 39 & 13 & ausencia & $<100$ & - \\
\hline 42 & 14 & aLıSËcia & $\therefore 100$ & - \\
\hline 45 & 15 & ausencia & $<100$ & - \\
\hline 48 & 16 & ausencia & $<100$ & - \\
\hline 51 & 17 & presenca & $\therefore 100$ & A. caviae \\
\hline 54 & 18 & presenca & $2,1 \times 10^{4}$ & A. caviae \\
\hline 57 & 19 & presenca & $<100$ & A. caviae \\
\hline 60 & 20 & ausencia & $<100$ & - \\
\hline 6.5 & 21 & presença & $9,6 \times 10^{0}$ & A. caviae \\
\hline 66 & 22 & ausencia & 100 & - \\
\hline 69 & 23 & ausencia & $<100$ & - \\
\hline 72 & 24 & presença & 100 & A. caviae \\
\hline 75 & 25 & ausencia & $<100$ & - \\
\hline 78 & 26 & presenca & $<100$ & A. caviae \\
\hline 81 & 27 & presenca & $<100$ & A. caviae \\
\hline 84 & 28 & presenca & $1,4 \times 10=$ & A. caviae \\
\hline 87 & 29 & ausencia & $\measuredangle 100$ & - \\
\hline 90 & 30 & ausencia & $<100$ & - \\
\hline
\end{tabular}


Tabela 6 Variaveis estatisticas das contagens de Aeromonas spp. para as diferentes hortalicas analisadas, em UFC/g, Să F'aulo, 1993.

\begin{tabular}{|c|c|c|c|c|}
\hline HORTALICAA & $\begin{array}{l}\text { VARIACFAO DA } \\
\text { CONTAGEM }\end{array}$ & MEDIANA & $\begin{array}{c}\text { MEDIA } \\
\text { ARITMETICA }\end{array}$ & $\begin{array}{l}\text { MEDIA } \\
\text { GEOMETRICA }\end{array}$ \\
\hline ALFACE & $\left\langle 10=\right.$ a $2,0 \times 10^{\circ}$ & $10=$ & $4,98 \times 10^{3}$ & $2,74 \times 10=$ \\
\hline AGRIAO & $10=\approx 2,0 \times 100$ & $1,2 \times 10=3$ & $7,94 \times 10^{4}$ & $1,49 \times 10^{3}$ \\
\hline ESCAROLA & $10=$ a $2,1 \times 10^{4}$ & $\angle 10=$ & $1,12 \times 10=$ & $1,44 \times 10=$ \\
\hline TOTAL & $\angle 10^{\circ}=$ a $2,0 \times 10^{\circ}$ & $\angle 10=$ & $2,95 \times 10^{4}$ & $3,98 \times 10=$ \\
\hline
\end{tabular}


Tabela 7 Distribuicå das amostras de diferentes hortalicas e respectivos percentuais segundo a contagem de Aeromonas spp., Să Faulo, 1993.

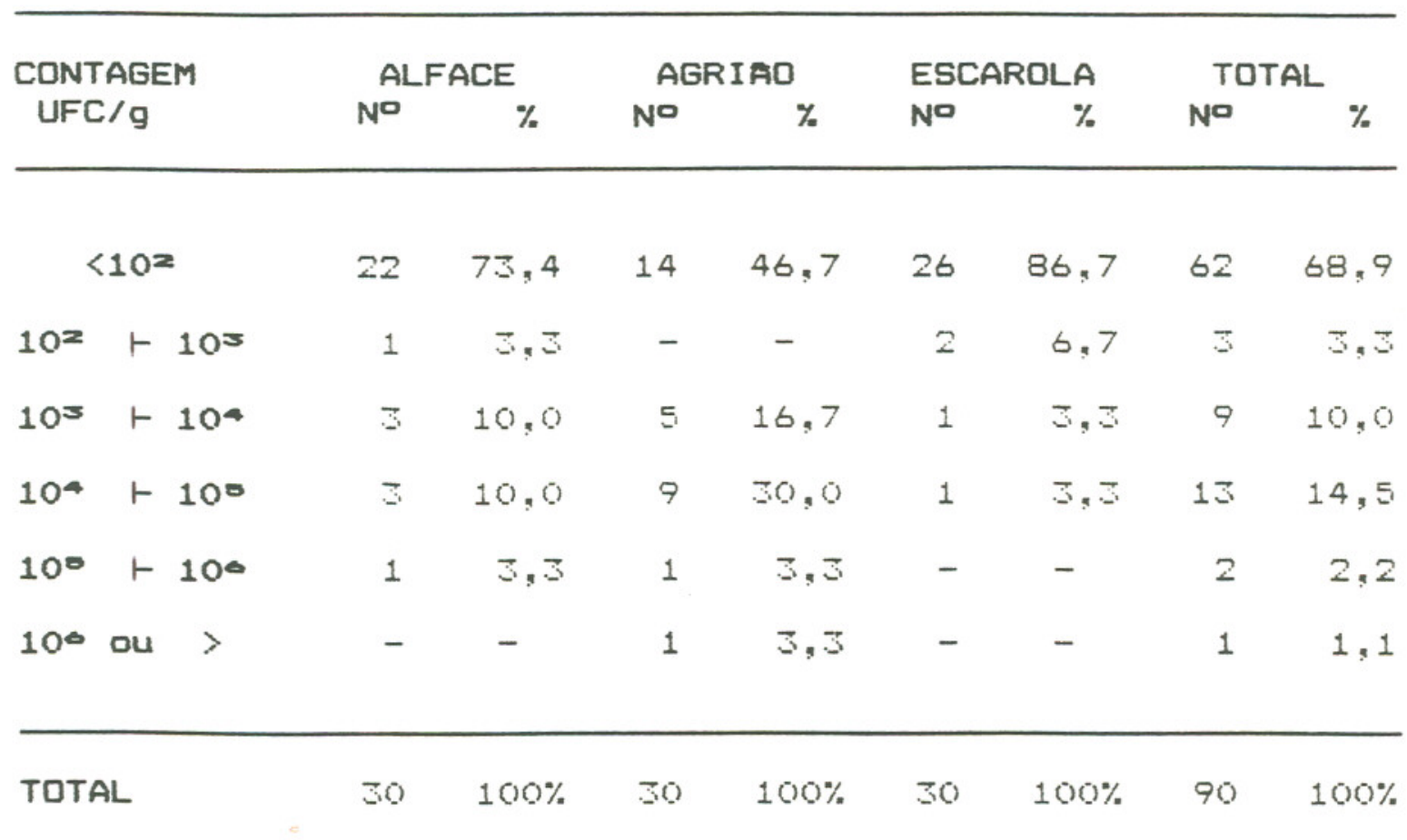

UFC/g - unidades formadoras de colonias/grama 

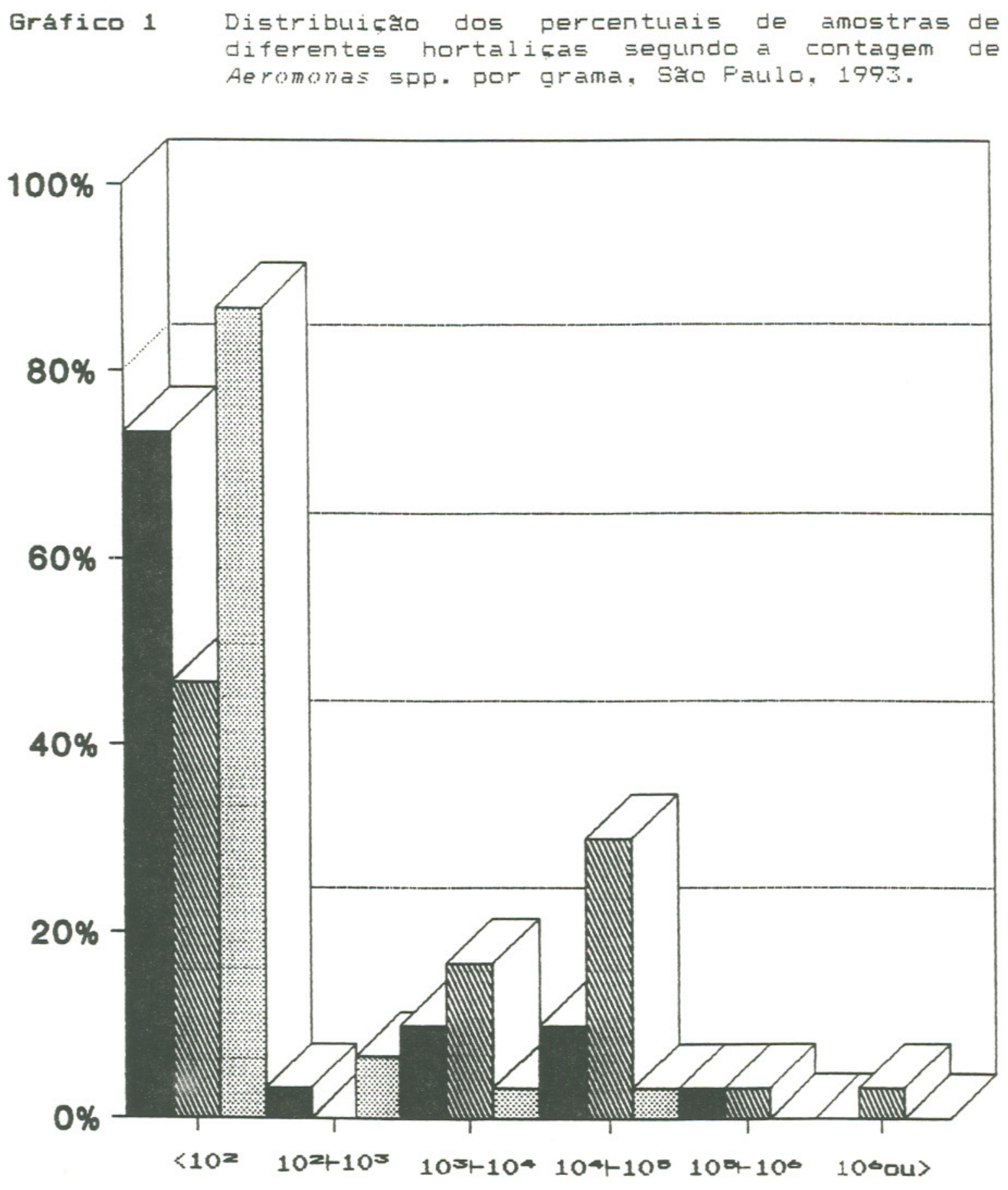

ALFACE $\mathbb{M}$ AWW AGIAO 
Tabela 8 Fositividade absoluta e relativa das amostras de hortalicas analisadas frente as duas metodologias de isolamento de Aeromonas spp. Litilizadas, Săo Faulo, 1993.

\begin{tabular}{|c|c|c|c|c|}
\hline AMOSTRAS & ALFACE & AGRIAO & ESCAROLA & TOTAL \\
\hline ANALISADAS & 30 & 30 & 30 & 90 \\
\hline POSITIVAS (+) & $\begin{array}{c}13 \\
43,3 \%\end{array}$ & $\begin{array}{c}21 \\
70,0 \%\end{array}$ & $30^{9}, 0 \%$ & $\begin{array}{c}43 \\
47,8 \%\end{array}$ \\
\hline PRES/AUS + & $30,0 \%$ & $\begin{array}{c}17 \\
56,7 \%\end{array}$ & $30,0 \%$ & $\begin{array}{c}35 \\
38,9 \%\end{array}$ \\
\hline CONTAGEM + & $\begin{array}{c}8 \\
26,7 \%\end{array}$ & $53.3 \%$ & $13^{4}, 3 \%$ & $\begin{array}{l}28 \\
31,1 \%\end{array}$ \\
\hline $\begin{array}{l}\text { PRES/AUS + } \\
\text { CONTAGEM - }\end{array}$ & $16,7 \%$ & $16,7 \%$ & $16,7 \%$ & $\begin{array}{c}15 \\
16,7 \%\end{array}$ \\
\hline $\begin{array}{l}\text { CONTAGEM + } \\
\text { PRES/AUS - }\end{array}$ & $13,3 \%$ & $13,3 \%$ & $\begin{array}{l}\circ \\
0 \%\end{array}$ & $\begin{array}{c}8 \\
8,9 \%\end{array}$ \\
\hline $\begin{array}{l}\text { PRES/AUS + } \\
\text { CONTAGEM + }\end{array}$ & $13^{4}, 3 \%$ & $\begin{array}{l}12 \\
40,0 \%\end{array}$ & $13,3 \%$ & $\begin{array}{c}20 \\
22,2 \%\end{array}$ \\
\hline $\begin{array}{l}\text { PRES/AUS + } \\
\text { CONTAGEM + } \\
\text { em rel.ao } \\
\text { total de + }\end{array}$ & $30,8 \%$ & $57,1 \%$ & $44,4 \%$ & $46,5 \%$ \\
\hline
\end{tabular}


Tabela 9 Cepas isoladas e confirmadas como Aeromonas spp. e respectiva percentagem para cada 10 amostras e para o total de amostras de hortalifas analisado, Săo Paulo, 1993.

\begin{tabular}{lccc}
\hline $\begin{array}{c}\text { AMOSTRAS } \\
\text { NO }\end{array}$ & $\begin{array}{c}\text { NO DE CEPAS } \\
\text { ISOLADAS }\end{array}$ & $\begin{array}{c}\text { CEPAS } \\
\text { NO }\end{array}$ & $\begin{array}{c}\text { CONFIRMADAS } \\
\%\end{array}$ \\
\hline 1 a 10 & 23 & 6 & 26,1 \\
11 a 20 & 11 & 9 & 81,8 \\
21 a 30 & 11 & 11 & 100,0 \\
31 a 40 & 9 & 6 & 66,7 \\
41 a 50 & 18 & 12 & 66,7 \\
51 a 60 & 30 & 26 & 86,7 \\
61 a 70 & 23 & 22 & 95,6 \\
71 a 80 & 26 & 21 & 80,8 \\
81 a 90 & 36 & 30 & 83,5 \\
\hline TOTAL & 187 & 143 & 76,5 \\
\hline TOTAL EXCLUINDO & 164 & 137 & 83,5 \\
AMOSTRAS 1 a 10 & & & \\
\hline
\end{tabular}


Tabela 10 Número e percentagem das amostras positivas para Aeromonas spp. e para as suas diferentes especies isoladas, distribuldas segundo os tipos de hortaliças analisadas, Săo Faulo, 1993.

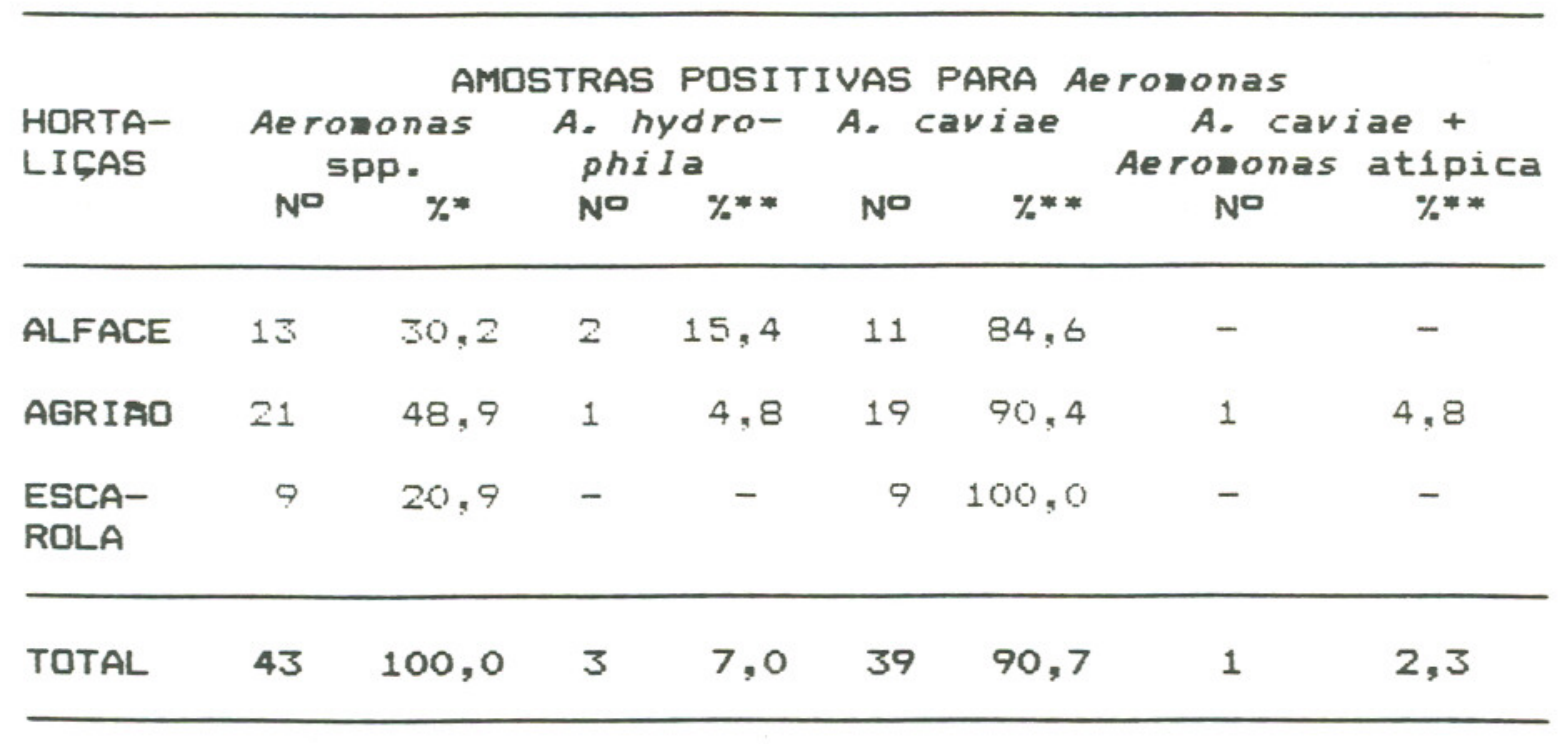

* Percentages en relacto ao total de anostras positivas.

* * Percentagen es relasto as anostras positivas para Aeromonas spp., total e de cada tipo de hortalica. 
Tabela 11 Fositividade nos testes bioquimicos e microscopicos utilizadas na identificaço das 4 cepas de A. hydrophila e 138 de A. caviae isoladas de amostras de hortaliças, Să Faulo, 1993.

\begin{tabular}{|c|c|c|c|c|}
\hline Testes & A. & hydrophila & A. & caviae \\
\hline Dxidase & 4 & $(100,0)^{*}$ & 138 & $(100,0)^{*}$ \\
\hline Catalase & 4 & $(100,0)$ & 138 & $(100,0)$ \\
\hline Bacilo Gram - & 4 & $(100,0)$ & 138 & $(100,0)$ \\
\hline Motilidade & 4 & $(100,0)$ & 138 & $(100,0)$ \\
\hline Nitrato & 4 & $(100,0)$ & 138 & $(100,0)$ \\
\hline Indol & 4 & $(100,0)$ & 134 & $(97,1)$ \\
\hline Glicose Q/F & 4 & $(100,0)$ & 138 & $(100,0)$ \\
\hline Flagelo polar & 4 & $(100,0)$ & 1.34 & $(97,1)$ \\
\hline Crescimento a $370 \mathrm{C}$ & 4 & $(100,0)$ & 138 & $(100,0)$ \\
\hline \multicolumn{5}{|l|}{ Crescimento em $\mathrm{NaCl}$} \\
\hline \multirow{2}{*}{$\begin{aligned} \text { a } 0 \% & \text { e } \\
\text { a } & 5 \%\end{aligned}$} & 4 & $(100,0)$ & 1.38 & $(100,0)$ \\
\hline & 0 & $(0,0)$ & 0 & $(0,0)$ \\
\hline \multicolumn{5}{|l|}{ Utilizaçสัด de } \\
\hline Sacarose & 4 & $(100,0)$ & 138 & $(100,0)$ \\
\hline Manitol & 4 & $(100,0)$ & 1.38 & $(100,0)$ \\
\hline Inositol & 0 & $(0,0)$ & 0 & $(0,0)$ \\
\hline Salicina & 4 & $(100,0)$ & 136 & $(98,6)$ \\
\hline Arabinose & 4 & $(100,0)$ & 138 & $(100,0)$ \\
\hline Esculina & 4 & $(100,0)$ & 138 & $(100,0)$ \\
\hline \multicolumn{5}{|l|}{ Froduçส̃o de gas } \\
\hline a partir da glicose & 4 & $(100,0)$ & 0 & $(0,0)$ \\
\hline Voges-Froskauer & 3 & $(75,0)$ & 2 & $(1,4)$ \\
\hline \multicolumn{5}{|l|}{ Utilizaçสัo de } \\
\hline Arginina & 4 & $(100,0)$ & 43 & $(31,2)$ \\
\hline Ornitina & 0 & $(0,0)$ & 0 & $(0,0)$ \\
\hline Lisina & 1 & $(25,0)$ & 1 & $(0,7)$ \\
\hline \multicolumn{5}{|l|}{ "CAMF-TEST" em } \\
\hline aerobiose & 4 & $(100,0)$ & 0 & $(0,0)$ \\
\hline anaerobiose & 4 & $(100,0)$ & 0 & $(0,0)$ \\
\hline
\end{tabular}

Nónero (z) de cepas con resposta positiva nos diferentes testes. 


\section{CONCLUSOES}

1. Os tres tipos de hortalicas analisados, alface, agriaro e escarola, revelaram-se com a presença de Aeromonas do grupo A. hydrophila por uma ou ambas as metodologias utilizadas. Essas bacterias foram encontradas em $43(47,8 \%)$ de 90 amostras de hortalicas analisadas, positividade esta que pode ser considerada alta.

2. A presença de Aeromonas do grupo A. hyorophila foi significativamente maior nas amostras de agriăo $(70,0 \%)$, quando comparada as de alface $(43,3 \%)$ e as de escarola $(50,0 \%)$, aplicando-se o teste de 2 proporçes com aproximaç̃o pela distribuị̧a normal a nivel de $5 \%$.

3. Observou-se uma grande variaçăo dos números de Aeromonas spp. detectados nas diferentes amostras de hortaliças, cujos Valores oscilaram de $<10=$ a $2 \times 100$ UFC/g.

4. Dentre as 43 amostras de hortalicas positivas para Aeromonas spp., $9(21,0 \%)$ apresentaram contagens destas bacterias superiores a $10^{4}$ UFC/g, sendo que 7 eram de agriă. Fara as demais amostras positivas os números encontrados foram de $10=$ a $104 \mathrm{UFC} / \mathrm{g}$. 
5. Verificou-se que os valores de positividade obtidos atraves da semeadura direta em placas e do teste de presenç/ausencia năo foram significativamente diferentes para as amostras de alface $e$ de agriäo. For outro 1 ado, relativamente às amostras de escarola, tal diferença foi significativa, revelando-se o teste de presença/ausencia mais eficiente, possivelmente devido ao fato de nenhuma das amostras desta hortalisa ter se mostrado positiva na contagem e negativa em teste de presença/ausencia.

6. Em um total de 187 cepas suspeitas isoladas, obteve-se a confirmaçăo de Aeromonas spp. de um número relativamente alto, ou seja, de 143 (76,5\%), sobretudo se forem excluidas as cepas provenientes das 10 primeiras amostras analisadas, elevando-se a percentagem de confirmadas para $83,5 \%$.

7. Das 143 cepas confirmadas como sendo de Aeromonas spp., $1.58(96,5 \%)$ eram de $A$. caviae, $4(2,8 \%)$ de A. hydrophila e 1 $(0,7 \%)$ que, embora tenha sido classificada como Aeromonas, foi atipica, levando em conta as suas caracteristicas bioquímicas. 
8. Do total de 45 amostras positivas para Aeromonas do grupo A. hydrophila, 39 (90,7\%) revelaram-se com a presenca exclusiva de A. caviae, 1 (2,3\%) de A. caviae e Aeromonas atipica e $3(7,0 \%)$ mostraram-se positivas somente para A. hydrophila, observando-se, portanto, grande predominancia de contaminaçăo com $A$. caviae.

9. Frente aos resultados obtidos, pode-se concluir que as hortalicas, dos tipos que foram analisados, podem representar risco à saúde, dado que as mesmas são consumidas cruas em larga escala em nosso meio. 


\section{REFERENCIAS BIBLIOGRAFICAS *}

ABEYTA Jr., C., KAYSNER, C.A., WEKELL, M.M., SULLIVAN, J.L., STELMA Jr., G.N. Recovery of Aeromonas hyorophila from oysters implicated in an outbreak of foodborne illness. J. Food Prot., Ames, $\vee .49, \pi .8, p .643-646,1986$.

ABEYTA JH., C., WEAGANT, S.D., KAYSNER, C.A., WEKELL, M.M., STOTT, R.F., KRANE, M.H., PEELER, J.T. Aeromonas hydrophila in shellfish growing waters: incidence and media evaluation J. Food Prot., Ames, $\vee .52, n .1, p .7-12$, 1989 .

ABEYTA Jr., C., WEKELL, M.M. Fotential sources of Aeromonas hydrophila. J. Food Saf., Westport, v.9, p.11-22, 1988.

AGBONLAHOR, D.E., SHONEKAN, R.A.O., KAZAK, W.H., COKER, A.Q. Aeromonas food poisoning in Nigeria: a case report. Cent. Afr. J. Med., Salisbury, v.28, ח.2, p.36-38, 1982.

AGGER, W.A., MCCORMICK, J.D., GURWITH, M.J. Clinical and microbiological features of Aeromonas hyorophilaassociated diarrhea. J. Clin. Microbiol. Washington, p.21, ח.6, p.909-913, 1985.

ALABI,S.A., ODUGBEMI,T. Biochemical characteristics and a simple scheme for the identification of Aeromonas species and Plesiomonas shigelloides. J. Trop. Med. Hyg., Oxford, $\vee .93$, n.S, p.166-169, 1990.

ALTWEGG, M.S., GEISS, H.K. Aeromonas hydrophila as a human pathogen. C R C -Crit. Rev. Microbiol., Cleveland, V.16, ก.4, p.253-286, 1989 .

ALTWEgG, M., STEIGEFWALT, A.G., ALTWEgG-BISSIG, F., LUTHYHOTTENSTEIN, J., BRENNER, D.J. Biochemical identification of Aeromonas genospecies isolated from humans. J. Clin. Microbiol., Washington, $\vee .28, \pi .2$, p. $258-264,1990$.

AMERICAN FUBLIC HEALTH ASSOCIATION (AFHA). Compendium of methods for the microbiological examination of foods. S.ed. Washington, 1992. 1219p.

* De acordo com a NBRG0ż/89 preconizada pela ASSOCIAÇaO BRASILEIRA DE NORMAS TECNICAS (ABNT). As abreviaturas dos titulas dos periddicos seguem a CHEMICAL ABSTRACTS SEFVICE SOURCE INDEX (CASSI), 1990 . 
ANNAFURNA, E., SANYAL, S.C. Enterotoxicity of Aeromonas hydrophila. J. Med. Microbiol.s Edinburgh, v.10, p.:17$323,1977$.

ARAUJO, F.M., ARRIBAS, F.M., FAFES, F. Distribution of Aeromonas species in waters with different levels of pollution. J. Appl. Bacteriol., Oxford, v.71, p.182-186, 1991.

ARCHEF, D.L., KVENBERG, J.E. Regulatory significance of Aeromonas in foods. J. Food Saf., Westport, v.9, p.5.$58,1988$.

ASAO, T., KINOSHITA, Y., KOSAKI, S., UEMURA,T., SAKAGUCHI, G. Furification and some properties of Aeromonas hydrophila hemolysin. Infect. Immun., Washington, v.46, n.1, p.122127,1984 .

BAFEF, M.F., MILLEFSHIP, S.E., TABAQCHALI, S. Relationship of toxin production to species in the genus Aeromonas. J. Med. Microbial., Edinburgh, v.22, p.30\$-309, 1986.

GARNHART,H.M., FANCORBO,O.C., DREESEN,D.W., SHOTTS J.., E.B. Recovery of Aeromonas hydrophila from carcasses and processing water in a broiler processing operation. J. Food Prot., Ames, $\vee .52, n .9,0.646-649,1989$.

BAUMANN, F., SCHUBERT, F.H.W. Vibrionaceae. In: KRIEG, N.F., HOLT, J.G., eds. Bergey's manual of systematic bacteriology. Baltimore: Williams \& Wilkins, 1984. V.1, p. 516-517.

BEFQUU, E.S., SOUZA, J.M.F', GOTLIEB,S.L.D. Bioestatistica. Să Paulo: E.F.U., 1981. 350p.

BERRANG, M.E., BRACKETT, F.E., BEUCHAT, L.R. Growth of Aeromonas hyorophila on fresh vegetables stored under a controlled atmosphere. Appl. Environ. Microbiol., Wastington, $\vee .55, n .9, \mathrm{p} .2167-2171,1989$.

BEUCHAT, L.R. Eehavior of Aeromonas species at refrigeration temperatures. Int. J. Food Microbiol., Amsterdam, $\vee .13$, ก.క, $.217-224,1991$.

BLICKSTAD, E., MOLIN, G. Carbon dioxide as a controller of the spoilage flora of pork, with special reference to temperature and sodium chloride. J. Food Prot." Ames, v.46, ח.9, $.756-763,1983$.

BORFEGO, J.J., MOFINIGO, M.A., MARTINEZ-MANZANARES, E., BOSCA, M., CASTRO, D., BARJA, J.L., TORANZO, A.E. Filasmid associated virulence properties of environmental isolates of Aeromonas hydrophila. J. Med. Microbiol., Edinburgh, $\vee .35$, p.264-269, 1991. 
BUCHANAN, R.L. The "new" pathogens: an lupdate of selected examples. Assoc. Food Drug Off., Fhiladelphia, v.48, p.142-155, 1984 .

BUCHANAN, Fi.L., FALUMBO, S.A. Aeromonas hydrophila and Aeromonas sobria as potencial food poisoning species: a review. J. Food Saf., Westport, v.7, p.15-29, 1985.

BURKE, $V$, COOFER, M., ROBINSON, J., GRACEY, M. , LESMANA, M., ECHEVERRIA, P., JANDA, J.M. Hemagglutination patterns of Aeromonas Spp. in relation to biotype and source. J. Clin. Microbiol., Washington, v.19, n.1, p.39-43, 1984a.

BURKE, V., GRACEY, M., ROBINSON, J., PECK, D., BEAMAN, J., BUNDELL, C. The microbiology of childhood gastroenteritis: Aeromonas species and other infective agents. J. Infect. Dis., Chicago, $\vee .148, n .1$, p.68-74, 1983.

BUFKE, V., ROBINSON, J., BERRY, F.J, GRACEY,M. Detection of enterotoxins of Aeromonas hydrophila by a suckling-mouse test. J. Med. Microbial., Edinburgh, v.14, p.401-408, 1981 .

BURKE, V., ROEINSON, J., COOFEF,M., BEAMAN, J., FARTFIDGE, K., PETERSON, D., GRACEY, M. Biotyping and virulence factors in clinical and environmental isolates of Aeromonas species. Appl. Environ. Microbiol., Washington, v.47, ก.5, p.1146-1149, 1984b.

BURKE, V., ROBINSON, J., GRACEY, M., PETERSON, D., MEYER, N., HALEY, $V$. Isolation of Ae romonas SPP. from an unchlorinated domestic water supply. Appl. Environ. Microbiol., Washington, $v .48, \pi .2, \mathrm{p} .367-370,1984 d$.

BURKE, $V$, FOBINSON, J . GRACEY,M. , PETERSON,D., PAFTRIDGE, K., Isolation of Aeromonas hyorophila from metropolitan water supply: seasonal correlation with clinical isolates. Appl. Environ. Microbiol., Washington, $\vee .48, \pi .2$, p.361$366,1984 \mathrm{C}$.

CALLISTEF, S.M., AGGER, W.A. Enumeration and characterization of Aeromonas hydrophila and Aeromonas caviae isolated from grocery store produce. Appl. Environ. Microbial., Washington, v.53, n.2, p.249-25., 1987.

CAMFBELL, J.D., HOUSTON, C.W. Effect of cultural conditions on the presence of a cholera-toxin cross-reactive factor in culture filtrates of Aeromonas hyorophila. Curr. Microbial., New York, v.12, n.2, p.101-106, 1985. 
CARNAHAN, A.M., BEHRAM, S., JOSEPH, S.W. AEROKEY II: a flexible key for identifying clinical Aeromonas species. J. Clin. Microbial., Washington, $\vee .29, \pi .12$, p.2843-2849, 1991.

CARRELLO, A., SILBURN, K.A., BUDDEN, J.F., CHANG, B.J. Adhesion of clinical and environmental Aeromonas isolates to HEp-2 cells. J. Med. Microbiol., Edinburgh, v.26, p. $19-27,1988$.

CASELITZ, F.H. Zur Frage von Pseudomonas aeruginosa und verwandten Microoganismen als Enteristiserreger. $Z$. Tropenmed. Parasitol., Stuttgart, v.9, p.269-276, 1958.

CHAKRABORTY, T., MONTENEGRO, M.A., SANYAL, S.C., HELMUTH,Fi., BULLING, E., TIMMIS, K.N. Cioning of enterotoxin from Aeromonas hydrophila provides conclusive evidence of production of a citotonic enterotoxin. Infect. Immun., Washington, $\vee .46, n .2$, p.455-441, 1984.

CHAMPSAUR, H., ANDREMONT, A., MATHIEU, D., ROTTMAN, E., AUZEPY, F. Cholera-like illness due to Aeromonas sobria. J. Infect. Dis., Chicago, v.145, n.2, p.248-254, 1982.

CHOPRA, A.K., VO, T.N., HOUSTON, C.W. Mechanism of action of a cytotonic enterotoxin produced by Aeromonas hydrophila. FEMS Microbiol. Lett., Amsterdam, V.91, p.15-20, 1992 .

CHOFRA, A.K., HOUSTON, C.W., GENAUX, C.T., DIXON, J.D., KUROSKY, A. Evidence for production of an enterotoxin and cholera toxin cross-reactive factor by Aeromonas hydrophila. J. Clin. Microbiol., Washington, v.24, n.4, p.661-664, 1986.

CHRISTIE, F., ATKINS, N.E., MUNCH-FETERSEN, E. A note on a lytic phenomenon shown by group B streptococci Aust. J. Exp. Biol. Med. Sci., Adelaide, v.23, p.197-200, 1944.

COLWELL, F.F., MacDONELL, M.T., DE LEY, J. Froposal to recognize the family Aeromonadaceae fam. nov. Int. J. Syst. Bacteriol., Washington, $\vee .36, \pi .3, p .473-477,1986$.

CONDON, S., GARCIA, M.L., OTERO, A., SALA, F.J. Effect of culture age, pre-incubation at low temperature and $\mathrm{pH}$ on the thermal resistance of Aeromonas hydrophila. J. Appl. Bacteriol.: 0xford, v.72, p.322-326, 1992.

CUMBERBATCH, N., GURWITH, M.J., LANGSTON, C., SACK, F.B., BRUNTON, J.L. Cytotoxic enterotoxin produced by Aeromonas hydrophila: relationship of toxigenic isolates to diarrheal disease Infect. Immun., Washington, $\vee .23$, ก.3, p.829-837, 1979 . 
DAILY, O.F'., JOSEFH, S.W., COOLBAUGH, J.C., WALKER, R...., MEFRELL, B.R., FULLINS, D.M., SEIDLER, R.J., CQLWELL, F.Fi., LISSNEF, C.R. Association of Ae romonas sobria with human infection. J. Clin. Microbiol., Washington, $\vee .1 \Xi$, ก.4, p.769-777, 1981 .

DAVIS, W.A., KANE, J.G., GAFAGUSI, U.F. Human Ae romonas infections: a review of the literature and a case report of endocarditis. Medicine, Baltimore, v.57, n.3, p.267277,1978 .

DEAN, A.G., CHING, Y.C., WILLIAMS, R.G., HARDEN, L.B. Test for Escherichia coli enterotoxin using infant mice: application in a study of diarrhea in children in Honolulu. J. Infect. Dis., Chicago, $\vee .125, \pi .4$, p.407411,1972 .

ECHEVEFRIA, F'., BLACKLOW, N.F., SANFORD, L.B., CUKOF, G.G. Travelers' diarrhea among American Feace Corps volunteers in rural Thailand. J. Infect. Dis., Chicago, V.143, ח.6, p. $767-771,1981$

ECHEVERRIA, P., HARRISON, B.A., TIRAFAT, C., MCFARLAND, A. Flies as a source of enteric pathogens in a rural village in Thailand. Appl. Environ. Microbiol., Washington, $\vee .46, \pi .1$, p. $32-36,1983$.

FAFBEF, J.M. Microbiological aspects of modified atmosphere packaging technology - a review. J. Food Prot., Ames, v.54, n.1, P.58-70, 1991.

FDA. 1985. Fathogen surveillance sampling of Aeromonas hydrophila in foods. Food Safety Compliance Frogram 7303-030 Apud: ABEYTA Jr., C., WEKELL, M.M. Fotential sources of Aeromonas hydrophila. J. Food Saf., Westport, V.9, P.11-22, 1988 .

FIGURA, N., GUGLIELMETTI, F. Differentiation of motile and mesophilic Aeromonas strains into species by testing for a CAMF-like factor. J. Clin. Microbiol., Washington, $\vee .25, \pi .7, p .1341-1342,1987$.

FIGURA, N., MARRI, L., VERDIANI, S., CECCHERINI, C., BABERI, A. Frevalence, species differentiation, and toxigenicity of Aeromonas strains in cases of childhood gastroenteritis and in controls. J. Clin. Microbiol., Washington, $\vee .23, n .3$, p.595-599, 1986.

FFICKEF, C.F., TOMFSETT, S. Ae romonas spp. in foods: a significant cause of food poisoning? Int. J. Food Microbiol., Amsterdam, $\vee .9, p .17-23,1989$. 
GHENGHESH, K.S. Aeromonas: epidemiological aspects and virulence factors. Săo Faulo, 1989. $192 \mathrm{p}$. [Tese de Doutorado - Escola Faulista de Medicina].

GOODWIN, C.S., HAFFEF, W.E.S., STEWART, J.K., GRACEY, M., BURKE, $V$., ROBINSON, J. Enterotowigenic Aeromonas hydrophila and diarrhoea in adults. Med. J. Aust., Sydney, $\vee .1, p .25-26,1983$.

GORDEN, R.W., HAZEN, T.C., ESCH,G.W., FLIERMANS, C.B. Isolation of Aeromonas hyorophila from the american alligator, Alligator mississippiensis. J. Wildl. Dis., Iowa, $\vee .15, \pi .2, p .239-43,1979$.

GFACEY, M., BUFKE, V., FOBINSON, J. Ae romonas-associated gastroenteritis. Lancet, London, $v .2$, p.1304-1306, 1982.

GRAM, L. Inhibition of mesophilic spoilage Aeromonas spp. on fish by salt, potassium sorbate, liquid smoke, and chilling. J. Food Prot., Ames, v.54, n.6, p.436-442, 1991.

GFAY, S.J., STICKLER, D.J., BRYANT, T.N. The incidence of virulence factors in mesophilic Aeromonas species isolated from animals and their environment. Epidemiol. Infect., Cambridge, v.105, F.277-294, 1990.

HAVELAAF, A.H., SCHETS, F.M., Van SILFHOUT, A., JANSEN,W.H., WIETEN, G., van der KOOIJ, D. Typing of Aeromonas strains from patients with diarrhoea and from drinking water. J. Appl. Bacteriol., Oxford, v.72, p.435-444, 1992.

HAZEN, T.C., FLIERMANS, C.E., HIFSCH, R.P., ESCH, G.W. Frevalence and distribution of Aeromonas hydrophila in the United States. Appl. Environ. Microbiol., Washington, $\vee .36, \pi .5,0.731-738,1978$.

HEIMEROOK, M.E., WANG, W.L.L., CAMFBELL, G. Staining bacterial fiagella easily. J. Clin. Microbiol., Washington, $\vee .27, n .11, p .2612-2615,1989$.

HEYWOOD, R. Aeromonas infection in snakes. Cornell Vet., Ithaca, $\vee .58, p .236-241,1968$.

HICKMAN-ERENNEF, F.W., FANNING, G.F.., ARDUINO, M.J., BRENNEF, D.J., FARMEF III, J.J. Aeromonas schubertit, a new manitol-negative species found in human clinical specimens. J. Clin. Microbiol., Washington, $\vee .26, n .8$, p.1561-1564, 1988 . 
HICKMAN-BRENNEF, F.W., MaCDONALD, K.L., STEIGERWALT, A.G., FANNING, G.F., BFENNEF, D.J., FARMEF III, J.J. Ae romonas reronis, a new ornithine decarboxylase-positive species that may calse diarrhea. J. Clin. Microbiol., Washington, $v .25, \pi .5, p .900-906,1987$.

HOLMBEFG, S.D., FARMER III, J.J. Aeromonas hyorophila and Plesiomonas shigelioides as causes of intestinal infections. Rev. Infect. Dis., Chicago, $\vee .6, \pi .5,0.633-$ $639,1984$.

HONDA, T., SATO, M., NISHIMURA, T., HIGASHITSUTSUMI, M., FUKAI,K., MIWATANI,T. Demonstration of cholera toxinrelated factor in cultures of Aeromonas species by enzymelinked immunosorbent assay. Infect. Immun., Washington, $\vee .50, \pi .1,0.322-323,1985$.

HUDSON, J.A., de LACY, K.M. Incidence of motile aeromonads in New Zealand retail foods. J. Food Prot. "Ames, V.54, ก.7, P. 696-699, 1991 .

HUGH, R., LEIFSON, E. The taxonomic significance of fermentative versus oxidative metabolism of carboydrates by various Gram-negative bacteria. J. Bacteriol., Washington, $v .66, p .24-26,1953$.

HUNTEF, F.F., BURGE, S.H. Isolation of Aeromonas caviae from ice-cream. Lett. Appl. Microbiol., Oxford, v.4, p. 45-46, 1987 .

IBRAHIM, A., Mac RAE, I.C. Incidence of Aeromonas and Listeria spp. in red meat and milk samples in Brisbane, Australia. Int. J. Food Microbiol., Amsterdam, $\vee .12$, p. 26.3-270, 1991 .

INTEFNATIONAL COMMISSION ON MICFOEIOLOGICAL SFECIFICATIONS FOF FOODS (ICMSF). Microorganisms in foods. 2.ed. Toronto: University of Toronto Press, 1978. v.1, 434p.

JANDA, J.M., BOTTONE, E.J., SKINNER, C.V., CALCATERRA, D. Phenotypic markers associated with gastrointestinal Aeromonas hydrophila isolates from symptomatic children. J. Clin. Microbiol., Wastington, $\vee .17, n .4$, p.588-591, 1983.

JANDA, J.M., DIXON, A., FAUCHEF,B., CLAFK,F.B., BOTTONE,E.J. Value of blood agar for primary plating and clinical implication of simultaneous isolation of Aeromonas hydrophila and Aeromonas caviae from a patient with gastroenteritis. J. Clin. Microbiol." Washington, $v .20$, ก.6, P.1221-1222, 1984 . 
JIANG, Z.D., NELSON, A.C., MATHEWSON, J.J., ERICSSON, C.D., DuFONT, H.L. Intestinal secretory immune response to infection with Aeromonas species and PIesiomonas shigelloides among students from the United states in Mexico. J. Infect. Dis., Chicago, v.164, p.979-982, 1971 .

JIWA, S.F.H. Enterotoxigenity, hemaglutination and cell -surface hydrophobicity in Aeromonas hydrophila, A. sobria and $A$. salmonicida. Vet. Microbiol., Amsterdam, $\vee .8, p .17-34,1983$.

JOSEFH, S.W., COLWELL, Fi.F., MacDONELL, M.T. Aeromonas taxonomy. Experientia, Basel, $\vee .4 \Xi, n .4,0.349-350$, 1987 .

JUSEPH, S.W., JANDA, M., CAFNAHAN, A. Isolation, enumeration and identification of Aeromonas Sp. J. Food Saf., Westport, $\vee .9,0.23-35,1988$.

KETOVER, B.F., YOUNG, L.S., ARMSTRONG, D. Septicemia due to Aeromonas hydrophila: clinical and immunological aspects. J. Infect. Dis., Chicago, v.127, n.3, p.284-290, 1973.

KIROV, S.M., ANDERSON, M.J., MCMEEKIN, T.A. A note on Aeromonas spp. from chickens as possible food-borne pathogens. J. Appl. Bacteriol., Qxford, v.68, P. $327-334$, 1990 .

KNOCHEL, S., JEPFESEN, C. Distribution and characteristics of Aeromonas in food and drinking water in Denmark. Int. J. Food Microbiol., Amsterdam, v.10, n.4, p.317-322, 1990 .

KOBAYASHI, K., OHNAKA, T. Food poisoning due to newly recognized pathogens. Asian Med. J.. Tokyo, V.32, n.1, p.1-12, 1989 .

KIONEMAN, E.W., ALLEN, S.D., DOWELL Jr., V.F., JANDA, W.M., SOMMERS, H.M., WINN Jr., W.C. Color atlas and textbook of diagnostic microbiology, J.ed. Fhiladelphia: J.B. Lippincott, 1988. p. $343-344$.

KORBEL, F.., KOSTERS, J. Seuchenhaftes Sterben von Wildvogeln nach Aeromonas hydrophila Infektion. Tierarztl. Prax., Stuttgart, $\vee .17, n .3, p .297-298,1989$.

KROVACEK, K., FARIS,A., BALODA,S.B., LINDBERG,T., FETERZ,M., MANSSON, I. Isolation and virulence profiles of Aeromonas spp. from different municipal drinking water supplies in Sweden. Food Microbiol., London, $\vee .9, \Pi .3$, p.215-222, $1992 \mathrm{~b}$. 
KROVACEK, K., FARIS,A., EALODA,S.B., FETEFZ,M., LINDBEFG,T., MANSSON, I. Prevalence and characterization of Aeromonas spp. isolated from foods in Uppsala, Sweden. Food Micrabial., Londan, $v .9, \pi .1, p .29-36,1992 a$.

KROVACEK, K., FARIS, A., MANSSON, I. Growth of and toxin production by Aeromonas hyorophila and Aeromonas sobria at low temperatures. Int. J. Food Microbiol.. Amsterdam, v.13, ח.2, p.165-176, 1991.

KUIJFER, E.J., STEIGERWALT, A.G., SCHOENMAKERS, B.S.C.I.M., PEETERS, M.F., ZANEN, H.C., BRENNER, D.J. Phenotypic characterization and DNA relatedness in human fecal isolates of Aeromonas spp. J. Clin. Microbial., Washington, $\vee .27, n .1, p .132-138,1989$.

LAWSON, M.A., BURKE, V., CHANG, B.J. InVasion of HEp-2 celis by fecal isolates of Aeromonas hydrophila. Infect. Immun.s Washington, $\vee .47, \Pi .3, p .680-685,1985$.

LEITAO, M.F.F., SILVEIRA, N.F.A. Aeromonas spp. e PIesiomonas shigelloides na kgua, pescado e hortaliças, no estado de så Fiaulo. Colet. Inst. Tecnol. Aliment., Campinas, v.21, n.1, p.90-99, 1991.

LEUNG, C.K., HUANG, Y.W., FANCORBO, O.C. Bacterial pathogens and indicators in catfish and pond environments. J. Food Prot., Ames, v.55, ח.6, p.424-427, 1992.

LJUNGH, A., FOFOFF, M., WADSTFOM, T. Ae romonas hydrophila in acute diarrheal disease: detection of enterotoxin and biotyping of strains. J. Clin. Microbiol., Washington, $\vee .6, n .2,0.96-100,1977$.

LJUNGH, A., WRETLIND, B., MOLLEY, Fi. Separation and characterization of enterotoxin and two haemolysins from Aeromonas hydrophila. Acta Pathol. Microbiol. Scand. Sect. B, Copenhagen, V.89, p.387-397, 1981.

Mac FADDIN, J.F.

Biochemical tests for identification of medical bacteria. Baltimore: Williams \& Wilkins, 1976. $312 p$.

MAJEED, K.N., EGAN, A.F., MacFAE, I.C. Enterotoxigenic aeromonads on retail lamb meat and offal. J. Appl. Bacterial., Qxford, $\vee .67, p .165-170,1989$.

MAJEED, K.N., EGAN, A.F., MacRAE, I.C. Production of exotoxins by Aeromonas 5pP. at 50C. J. Appl. Bacteriol., Qxford, $\vee .69,0.332-337,1990$. 
MAJEED, K.N., Mac RAE, I.C. Experimental evidence for toxin production by Aeromonas hydrophila and Aeromonas sobria in a meat extract at low temperatures. Int. J. Food Microbiol., Amsterdam, v.12, p.181-188, 1991.

MARCUS, L.C. Infectious diseases of reptiles. J. Am. Wet. Med. Assoc., Chicago, v.159, п.11, p.1626-1651, 1971.

MARTINEZ-MANZANARES, E., MORINIGO, M.A., CORNAX,R., EGEA,F., BORFEGO, J.J. Fielationship between classical indicators and several pathogenic microorganisms involved in shellfish - borne diseases. J. Food Prot., Ames, $\vee .54$, ก.9, $.711-717,1991$.

MARTINEZ-SILVA, F., GUZMANN-UFFEGO, M., CASELITZ, F.H. ZUI Frage der Bedeutung von Aeromonasstummen bei Sauglingsenterites. Z. Tropenmed. Parasitol., Stuttgart, $\vee .12, p .445-451,1961$.

MILLEF, Fi.M., CHAPMAN, W.R. Epistylis sp. and Aeromonas hydrophila infections in fishes from North Carolina reservoirs. Prog. Fish Cult., v.38, p.165-168, 1976 Apud: BUCHANAN, F.L., FALUMBO, S.A. Aeromonas hydrophila and Aeromonas sobria as potencial food poisoning species: a review. J. Food Saf., westport, v.7, p.15-29, 1985.

MOIF, C.J., EYLES, M.J. Inhibition, injury and inactivation of four psychrotrophic foodborne bacteria by the preservatives methyl p-hydroxybenzoate and potassium sorbate. J. Food Prot., Ames, v.55, $0.5,0.360-366$, 1992.

MONFORT, F., BALEUX, B. Dynamics of Aeromonas hydrophila, Aeromonas sobria, and Aeromonas caviae in a sewage treatment pond. Appl. Environ. Microbiol., Washington, v.56, ח.7, p.1999-2006, 1990 .

MORGAN, D.F., JOHNSON, F.C., DLFONT, H.L., SATTERWHITE, T.K., WOOD, L.V. Lack of correlation between known virulence properties of Aeromonas hydrophila and enteropathogenicity for humans. Infect. Immun., Washington, $\vee .50, n .1,0.62-65,1985$.

MOFGAN, D.F., WOOD, L.V. Is Aeromonas Sp. a foodborne pathogen? Review of the clinical data. J. Food Saf., Westport, $\vee .7$, p.59-72, 1988.

MOYEF, N.F. Clinical significance of Aeromonas species isolated from patients with diarrhea. J. Clin. Microbiol.: Washington, v.25, n.11, p.2044-2048, 1987. 
NAMDARI, H., BOTTONE, E.J. Microbiologic and clinical
evidence supporting the role of Aeromonas caviae as a
pediatric enteric pathogen.
Washington, $v .28, n .5,0.857-840,1990$. Clin. Microbiol.,

NAMDAFI, H., BOTTONE, E.J. Cytotoxin and enterotoxin production as factors delineating enteropathogenicity of Aeromonas caviae. J. Clin. Microbiol., Washington, v.28, n.8, p.1796-1798, 19906.

NAMDARI, H., BOTTONE, E.J. Aeromonas caviae: Ecologic adaptation in the intestinal tract of infants coupled to adherence and enterotoxin production as factors in enteropathogenicity. Experientia, Basel, v.47, p.434436,1991 .

NEVES, M.S., NUNES, M.F., RICCIARDI, I.D. Incidence of motile Aeromonas species in aquatic environments of Fio de Janeiro; Brazil. J. Food Prot., Ames, v.5s, ח.1, p. $78-80,1990$.

NISHIKAWA, Y., KISHI, T. Isolation and characterization of motile Aeromonas from human, food and environmental specimens. Epidemiol. Infect., Cambridge, v.101, p.213$223,1988$.

NOTERMANS, S., HAVELAAF, A., JANSEN, W., KOZAKI, $5 .$, GUINEE,F'. Froduction of "Asao Toxin" by Aeromonas strains isolated from feces and drinking water. J. Clin. Microbiol., Washington, v.23, n.6, p.1140-1142, 1986.

OLIVEIRA, C.A.F., GERMANO, P.M.L. Estudo da ocorrencia de enteroparasitas em hortalicas comercializadas na regiao metropolitana de Såo Faulo, SF, Brasil. I- Fesquisa de helmintos. Rev. Saúde Pública, Så Faulo, v.26, ח.4, p.283-289, 1992 .

OKREND, A.J.G., FIOSE, B.E., BENNETT, B. Incidence and toxigenicity of Aeromonas species in retail poultry, beef and pork. J. Food Prot., Ames, v.50, n.6, p.509-513, 1987.

FALUMBO, S.A. Is refrigeration enough to restrain foodborne pathogens? J. Food Prot., Ames, V.49, n.12, p.10031009,1986 .

FALUMBO, S.A., BENCIVENGO, M.M., DEL COFRAL, F., WILLIAMS, A.C., BUCHANAN, R.L. Characterization of the Aeromonas hyorophila group isolated from retail foods of animal origin. J.Clin. Microbiol., Washington, $\vee .27, n .5$, p.854-857, 1989 . 
FALUMBO, S.A., BUCHANAN, R.L. Factors affecting growth or survival of Aeromonas hydrophila in foods. J. Food Saf., Westport, $v .9, p .37-51,1988$.

FALLIMBO, S.A., MAXINO, F., WILLIAMS, A.C., BLCHANAN, FI.L., THAYER, D.W. Starch-ampicillin agar for the quantitative detection of Aeromonas hydrophila. Appl. Environ. Microbiol., Washington, $\vee .50, \pi .4, p .1027-1030,1985 a$.

PALUMBO, S.A., MORGAN, D.F., BUCHANAN, R.L. Influence of temperature, NaCl, and $\mathrm{pH}$ on the growth of Aeromonas hydrophila. J. Food Sci., Chicago, v.50, p.1417-1421, 1985b.

FALUMBO, S.A., WILLIAMS, A.C. Growth of Aeromonas hydrophila k144 as affected by organic acids. J. Food Sci., Chicago, $\vee .57, \pi .1, p .233-235,1992 a$.

FALUMBO, S.A., WILLIAMS, A.C., BUCHANAN, R.L., FHILLIFS,J.G. Thermal resistance of Aeromonas hydrophila. J. Food Prot.: Ames, v.50, ก.9, p.761-764, 1987.

PALUMBO, S.A., WILLIAMS, A.C., BUCHANAN, R.L., PHILLIFS,J.G. Model for the aerobic growth of Aeromonas hyorophila k144. J. Food Prot., Ames, $\vee .54, n .6,0.429-435,1991$.

PALUMBO, S.A., WILLIAMS, A.C., BULHANAN, R.L., PHILLIFS,J.g. Model for the anaerobic growth of Aeromonas hydrophila k144. J. Food Prot., Ames, v.55, n.4, p.260-265, 1992b.

FITARANGSI, C., ECHEVERRIA, F., WHITMIRE, R., TIRAPAT, C., FORMAL, S., DAMMIN, G.J., TINGTALAFONG, M. Enteropathogenicity of Aeromonas hydrophila and Plesiomonas shigelloides: prevalence among individuals with and without diarrhea in Thailand. Infect. Immun., Washington, v.35, n.2, p.666-673, 1982.

F'OFFE, R., OF de BEECK, E. Enumeration of Aeromonas hydrophila from domestic wastewater treatment plants and surface waters. J. Appl. Bacteriol., Oxford, v.71, p. $366-370,1991$.

FOFOFF, M. Aeromonas. In: KRIEG, N.R., HOLT, J.G., eds. Bergey's manual of systematic bacteriology. Ealtimore, Williams \& Wilkins, 1984. v.1. p.545-548.

FOFOFF, M., LALLIEF, R. Characterization of Aeromonas. Methods Microbial., London, $v .16, p .128-145,1984$.

RAHMAN, A.F.M.S., WILLOUGHEY, J.M.T. Dysentery-like syndrome associated with Aeromonas hydrophila. Brit. Med. J., London, v.281, P.976, 1980. 
FIGNEY, M.M., ZILINSKY, J.W., ROUF, M.A. Fathogenicity of Aeromonas hydrophila in red leg disease in frogs. Curr. Microbiol., v.1, p.1175-1179, 1978 ApLd: BUCHANAN, R.L., FAlUMBO, S.A. Aeromonas hydrophila and Aeromonas sobria as potencial food poisoning species: a review. J. Food Saf., Westport, v.7, p.15-29, 1985.

FiffFEY, S.Fi., CABELLI, V.J. Membrane filter procedure for enumeration of Aeromonas hydrophila in fresh waters. Appl. Environ. Microbiol., Washington, $\vee .38, n .1, p .108-$ 113,1979 .

RODFIGUES, J. Aeromonas 5p. - Incidencia em alimentos e estudo de caracteristicas associadas a virulencia. Campinas, 1992. 104 p. [Dissertaça de Mestrado Universidade Estadual de Campinas].

SAKAZAKI, Fi., SHIMADA, T. O-serogrouping scheme for mesophilic Aeromonas strains. Jpn. J. Med. Sci. Biol., Tokyo, $\vee .37, p .247-255,1984$.

SANYAL, S.C., SINGH, S.J., SEN, F.C. Enteropathogenicity of Aeromonas hydrophila and Plesiomonas shigelloides. J. Med. Micrabiol., Edinburgh, v.8, n.1, p.195-199, 1975.

SCHULTZ, A.J., MECARDELL, B.A. DNA homology and immunological cross-reactivity between Aeromonas hydrophila cytotonic toxin and cholera toxin. J. Clin. Microbiol., Washington, $\vee .26, \pi .1, p .57-61,1988$.

SHILKIN, K.B., ANNEAR, D.I., ROWETT, L.R., LAURENCE, B.H. Infection due to Aeromonas hyorophila Med. J. Aust., Sydney, $\vee .1, \pi .9, p .351-35.3,1968$.

SHOTTS, E.E., GAINES, J.L., MARTIN, L., FRESTWOOD, A.K. Aeromonas-induced deaths among fish and reptiles in an eutrophic inland lake. J. Am. Vet. Med. Assoc., Chicago, v.161, n.6, p.603-607, 1972 .

STELMA Jr., G.N. Virulence factors associated with pathogenicity of Aeromonas isolates. J. Food Saf., Westport, $\vee .9, p .1-10,1988$.

STERN, N.J., DFAZEK, E.S., JUSEFH, S.W. LOW incidence of Aeromonas sp. in livestock feces. J. Food Prot. Ames, V.50, ח.1, p.66-69, 1987.

TEFNSTFOM, A., MOLIN, G. Incidence of potential pathogens on raw pork, beef and chicken in Sweden, with special reference to Erysipelothrix rhusiopathiae. J. Food Prot., Ames, $\vee .50, \pi .2$, p.141-146, 1987. 
THELEN, F., EURKE, $V .$, GRACEY, M. Effects of intestinal micro-organisms on fluid and electrolyte transport in the jejunum of the rat. J. Med. Microbiol.; Edinburgh, v.11, ก.4, p.465-470, 1978.

TITTSLEF, F.F', SANDHOLZEF, L.A. The lise of semi-solid agar for the detection of bacterial motility. J. Bacteriol., Washington, $\vee .31, n .6, p .575-580,1936$.

TODD, L.S., HARDY, J.C., STRINGEF, M.F., BARTHOLOMEW, B.A. Toxin production by strains of Aeromonas hydrophila grown in laboratory media and prawn puree. Int. J. Food Microbiol., Amsterdam, v.9, p.145-156, 1989.

TURNEULL, F.C.B., LEE, J.V., MILIOTIS,M.D., VAN DE WALLE,S., KOOFNHOF, H.J., JEFFEFY, L., BRYANT, T.N. Enterotoxin production in relation to taxonomic grouping and source of isolation of Aeromonas species. J. Clin. Microbiol., Washington, $\vee .19, n .2, p .175-180,1984$.

VAFINAM, A.H., EVANS, M.G. EVANS, M.G. 1991. P.185-200.
Aeromonas. pathogens.
In: VAFINAM, A.H., Aylesbury: Wolfe,

Von GRAEVENITZ, A. Fiesearch on Ae romonas and Plesiomonas: introduction. Experientia, Basel, v.43, n.4, P.348, 1987 .

Von GRAEVENITZ, A., MENSCH, A.H. The genus Aeromonas in human bacteriology. N. Engl. J. Med., Boston, V.278, p. $245-249,1968$.

WADSTROM, T., LJUNGH, A. Ae romonas and Plesiomonas as food and waterborne pathogens. Int. J. Food Microbiol., Amsterdam, $\vee .12, \pi .4,0.303-312,1991$.

WADSTRUM,T., LJUNGH,A., WRETLIND, B. Enterotoxin, haemolysin and cytotoxic protein in Aeromonas hydrophila from human infections. Acta Pathol. Microbiol. Scand., Sect. B, Copenhagen, $\vee .84, p .112-114,1976$.

WATSON, I.M., ROEINSON, J.O., BURKE, V., GRACEY, M. Invasiveness of Aeromonas spp. in relation to biotype, virulence factors, and clinical features. J. Clin. Micrabiol., Washington, $\vee .22, n .1, \mathrm{p} .48-51,1985$.

WEST, F.A., COLWELL, R.F. Identification and classification of Vibrionaceae - an overview. In: COLWELL, R.R., ed. Vibrios in the environment. New York: John Wiley, 1984. P.334-355.

WOHLGEMUTH, K., FIERCE, R.L., KIFKRRIDE, C.A. BOVInE abortion associated with Aeromonas hydrophila. J. Am. Vet. Med. Assoc., Chicago, v.160, n.7, p.1001-1002, 1972. 


\title{
VII. RESUMO
}

\begin{abstract}
Em um total de 90 amostras de hortaliças, incluindo 30 de alface, 30 de agriåo e 30 de escarola, foi verificada a ocorrencia de Aeromonas do grupo A. hydrophila, empregandose os metodos de semeadura direta em kgar amido-ampicilina (contagem) e apos enriquecimento em caldo tripticase-soja adicionado de ampicilina (teste de presenca/ausencia). As incubaçoses foram feitas a $28^{\circ} \mathrm{C}$, durante 24 horas. A presença dessas bacterias foi detectada em $43(47,8 \%)$ das amostras analisadas, com contagens variando de 102 a $2,0 \times 100 \mathrm{UFC} / g$. As amostras de agrião foram as que se revelaram, na contagem, com maiores números de Aeromonas spp. Das 43 amostras positivas para Aeromonas spp., $9(21,0 \%)$ revelaramse com números superiores a $104 \mathrm{UFC/g}$, sendo que 7 eram de agriăo. Dentre as amostras de hortaliças analisadas, as de agriă revelaram-se com positividade para Aeromonas do grupo A. hydrophila $(70,0 \%)$ significativamente maior em relaçăo as de alface $(43,3 \%)$ e de escarola $(30,0 \%)$ a nivel de $5 \%$. Nă foram
\end{abstract}




\begin{abstract}
observadas diferencas significativas entre as positividades obtidas através do metodo de semeadura direta em placas e do teste de presenca/ausencia para as amostras de alface e de agriå. Para as amostras de escarola, a positividade foi significativamente mais alta no teste de presenca/ausencia. Do total de 143 cepas confirmadas como sendo do genero Aeromonas, $\quad 138(96,5 \%)$ eram de $A$. caviae, $4(2,8 \%)$ de A. hydrophila e $1(0,7 \%)$ que, pelas suas caracteristicas, foi considerada como Aeromonas atipica. Dos resultados obtidos, pode-se depreender que as hortalicas dos tipos analisados, alface, agriăo e escarola, dado os niveis de contaminacăo observados, podem representar risco aos consumidores.
\end{abstract}




\section{SUMMARY}

A total of 90 retail vegetable samples, including 30 of lettuce, 50 of water-cress and 30 of escarole were examined for the presence of Aeromonas of the A. hyorophila group, using two different isolation methods. One of the methods envolved direct plating on starch-ampicillin agar for the purpose of enumeration and the other one, after enrichment in trypticase-soy broth with ampicillin, for detection, both using 24 hour incubation at 280C. Aeromonas spp. were detected in $4:(47.8 \%)$ samples and their numbers varied from less than $10^{2}$ up to $2.0 \times 10^{\circ}$ CFU/g. The water-cress samples were the ones to show greater numbers of Aeromonas spp. The counts of $9(21 \%)$ of the 43 positive samples exceeded $10^{4}$ CFU/g, 7 of them consisting of water-cress. The number of water-cress positive samples $(70.0 \%)$ was significantly higher at $5 \%$ than those of lettuce $(4.3 .5 \%$ ) and those of escarole $(30,0 \%)$. No significant differences were found in relation to positivity for Aeromonas spp. between both 
isolation methods used, regarding the lettuce and the watercress samples. On the other hand, with respect to the escarole samples, positivity was significantly superior for the isolation method envolving enrichment. In therms of species level identification, among 143 strains confirmed as being Aeromonas spp., 138 (96.5\%) were A. caviae, 4 (2.8\%) were $A$. hydrophila and $1(0.7 \%)$ was considered as atypical due to its different biochemical profile. The results show that the vegetables examined may represent risk to consumers in terms of presence and numbers of Aeromonas of the A. hydrophila group. 


\section{ANEXO}

\section{PREPARO DOS MEIOS DE CULTURA, SOLUCTOES E REAGENTES}

1. Soluçăo salina peptonada (ICMSF, 1978)

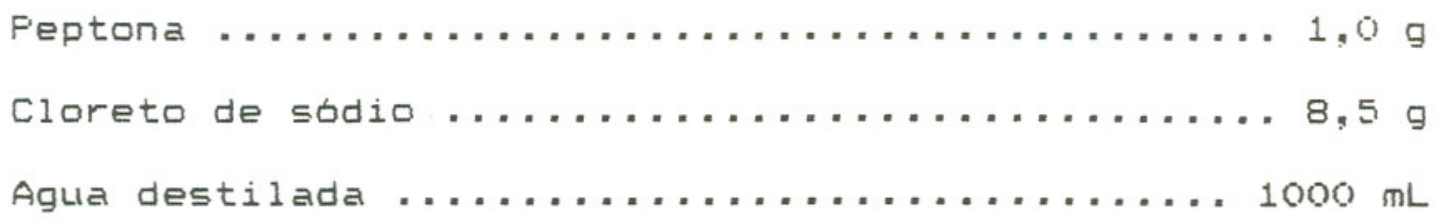

Após a dissoluçă dos ingredientes, esta soluçă era esterilizada em autoclave a 1210C durante 15 minutos, apos ter seu $\mathrm{pH}$ ajustado a $7,2 \pm 0,2$.

2. Agar amido-ampicilina (FALUMBO et al., 1985)

Caldo base vermel ho de fenol ........................ g

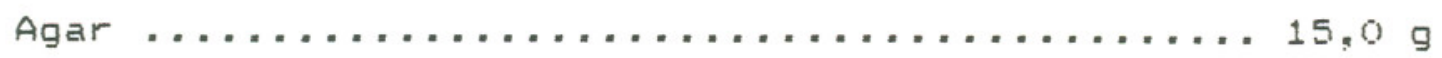

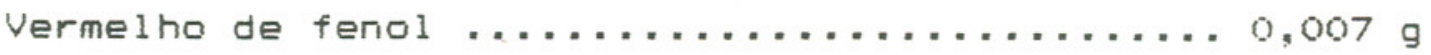

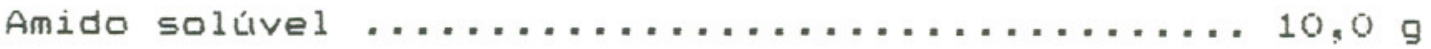
Agua destilada ................................................

a caldo base vermelho de fenol (Difco 0092) era adicionado de agar e de corante vermelho de fenol, em substituiço a ágar base vermelho de fenol (Difco 0098) recomendado por PALUMBO et al. (1985). A adiçă de corante 
se fez necessteria, Lima vez que a quantidade de vermelho de fenol presente no caldo é 0,007 menor do que no agar vermelho de fenol. Os ingredientes eram dissolvidos por aquecimento $e \mathrm{pH}$ era ajustado a $7,4 \pm 0,2,5$ sendo esterilizado em autoclave a $1210^{\circ} \mathrm{C}$ durante 15 minutos.

Após o resfriamento do meio de cultura a aproximadamente 500C, adicionava-se certo volume de uma solução de ampicilina esteril de modo a obter uma concentraçăo final de 10 ug/mL no meio de cultura, ou seja, adicionava-se $1 \mathrm{~mL}$ de uma solucão de ampicilina a $10 \mathrm{mg} / \mathrm{mL}$ para cada litro de meio de cultura a ser preparado. A ampicilina utilizada para esse fim foi uma ampicilina vendida no comércio, de marca Benzotal 1000, fabricada pelo laboratorio Biossintetica. A ampicilina em questao, comercializada estéril por ser injetavel, era diluida a uma concentraça de $10 \mathrm{mg} / \mathrm{mL}$ em agua esterilizada por em autoclave a $1210^{\circ} \mathrm{C}$, por 20 minutos e armazenada em pequenas porç̧es sob congelamento até o momento de sua litilizaçăo.

Após a adiço de ampicilina segulida de homogeinizaçăo suave, o meio era distribuido em volumes de 15 a $20 \mathrm{~mL}$ em placas de Petri esterilizadas e, apds sua solidifificaça, mantido sob refrigeraçă por, no maximo, I dias, quando era lutilizado. 
3. Caldo tripticase-soja em concentraçăo dupla com ampicilina

- caldo (Difco 0370 ) era preparado em concentraça dupla à recomendada pelo fabricante, isto é, para cada litro de meio, eram necessarios $60 \mathrm{~g}$ ao inves de $50 \mathrm{~g}$. Apos a sua dissoluça, o meio de cultura era distribuido em tubos de ensaio com capacidade para $30 \mathrm{~mL}$, em volumes de $10 \mathrm{~mL}$ e esterilizado em autoclave a $1210 \mathrm{C}$ durante 15 minutos. No momento da anklise, era adicionado um volume de soluçă esteril de ampicilina em cada tubo, de maneira a se obter, após a adiça de $10 \mathrm{~mL}$ da amostra diluida a $10^{-1}$, uma concentraçăo final de $10 \mathrm{ug} / \mathrm{mL}$.

\section{Agar tripticase-soja (0xoid)}

Esse meio era preparado de acordo com as instrucaes do fabricante. Os tubos contendo o agar eram inclinados posteriormente à sua esterilizaçăo em autoclave a $121^{\circ} \mathrm{C}$ durante 15 minutos.

5. Agar triplice-açúcar-ferro (Difco 0265)

- meio era preparado conforme as instrucoses do fabricante. Assim, após a sua dissoluçă, era distribuido em volumes de $4 \mathrm{~mL}$ em tubos de ensaio $12 \times 120 \mathrm{~mm}$ e esterilizado em autoclave a $1210 \mathrm{C}$ durante 15 minutos. Apos a esterilizaçăo, os tubos eram mantidos inclinados em temperatura ambiente, até a sua solidificaçăo e, em seguida, mantidos sob refrigeraçă, a cerca de $4^{\circ} \mathrm{C}$. 
6. Agar semi-solido para teste de motilidade (TITTSLER \& SANDHOLZEF, 1956)

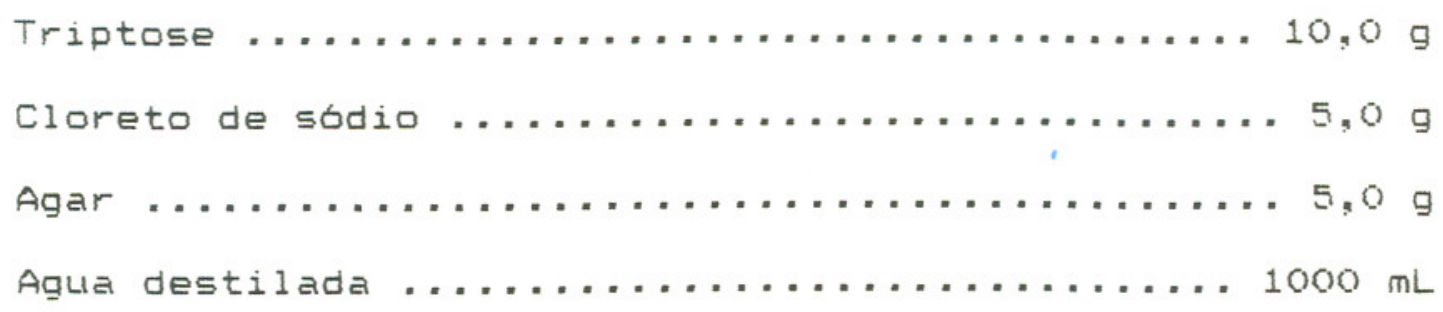

Apús a dissoluçăo dos ingredientes por aquecimento, o meio era distribuido em tubos $12 \times 120 \mathrm{~mm}$, em volumes de $3 \mathrm{~mL}$ e esterilizado em autoclave a $1210 \mathrm{C}$ durante 15 minutos. Após a esterilizaçăo, o meio era mantido em posiçă vertical até a sua solidificaçăo e, em seguida, mantido sob refrigeraça a cerca de $40 \mathrm{C}$. $0 \mathrm{pH}$ final era de 7,2 .

7. Caldo nitratado (Difco 0268)

Esse meio de cultura era preparado e esterilizado conforme as instruçoses do fabricante. Assim, apos a sua dissoluçăo, o meio era distribuldo em volumes de $3 \mathrm{~mL}$ em tubos de $12 \times 120 \mathrm{~mm}$ e esterilizado a $1210 \mathrm{C}$ durante 15 minutos. Após a esterilizaça, o meio era resfriado e mantido sob refrigeraçăo a cerca de $40 \mathrm{C}$. 
8. Agua peptonada a $1 \%$ para a prova do indol (ICMSF, 1978)

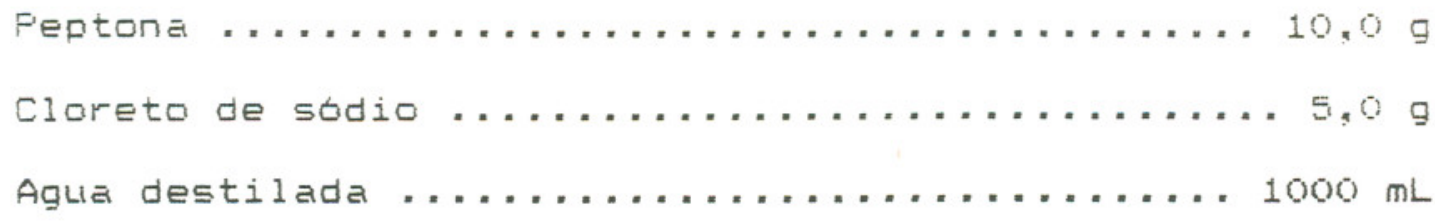

Os ingredientes eram dissolvidos, a pH era ajustado em $7,2 \pm 0,1$ e, apos sua distribuiçao em tubos $12 \times 120 \mathrm{~mm}$, o meio era esterilizado em autoclave a $1210 \mathrm{C}$ durante 15 minutos. Após a esterilizaçăo, o meio era resfriado e mantido sob refrigeraçăo a, aproximadamente, $4 \circ C$.

9. Meio para a prova de oxidaça/fermentaşăo da glicose

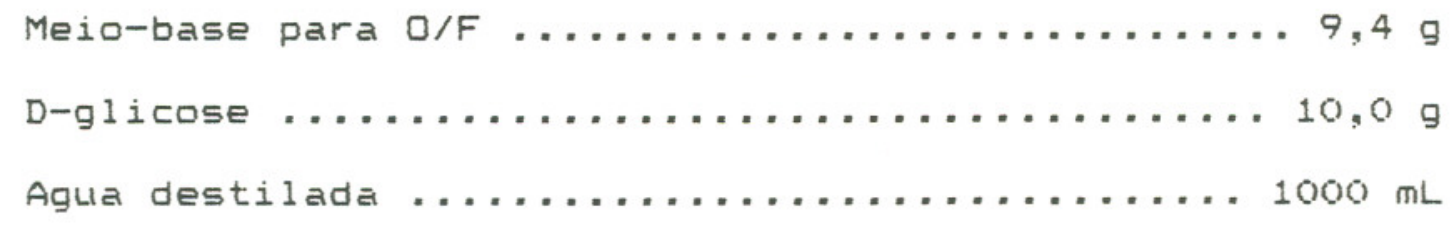

Esse meio era preparado, utilizando-se a base de Hugh e Leifson para O/F (Difco 0688). Os ingredientes eram dissolvidos por aquecimento, $\square \mathrm{pH}$ era ajustado a $6,8 \pm 0,2$ e, após sua distribuiçăo em volumes de $4 \mathrm{~mL}$ em tubos de $12 \times 120 \mathrm{~mm}$, o meio era esterilizado por autoclavacão a $121^{\circ} \mathrm{C}$ durante 10 minutos. Após a esterilizạ̧ă, o meio era resfriado e mantido sob refrigeraça a, aproximadamente, $4 \circ C$. 


\section{Caldo nutriente}

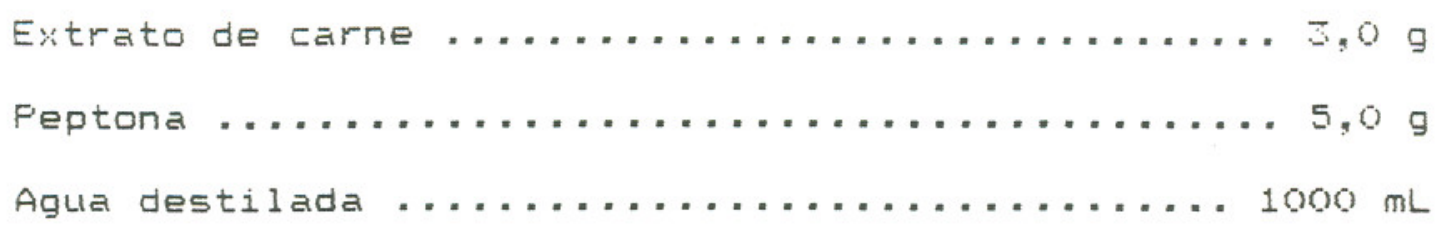

Após a dissoluçă dos ingredientes, o meio era distribuido em volumes de $2 \mathrm{~mL}$ em tubos de $12 \times 120 \mathrm{~mm}$. $\square \mathrm{pH}$ final da solucăo era de $6,8 \pm 0,2$. Os tubos contendo o meio eram esterilizados em autoclave a $1210 \mathrm{C}$ durante 15 minutos. Apos a esterilizaçăo, o meio era resfriado e mantido sob refrigeracăo a cerca de $40 \mathrm{C}$.

11. Caldo tripticase-soja - sem e com a adiça de cloreto de sodio

a caldo tripticase-soja (Difco 0370) era preparado conforme as instruçes do fabricante. Para a obtençăo de caldo com $3 \% \in 6 \%$ de cloreto de sodio, $2,5 \mathrm{~g}$ e 5,5\% desse sal eram adicionados, respectivamente, para cada $100 \mathrm{~mL}$ de meio, luma vez que o proprio meio contem, em sua formulaçă, $0,5 \%$ de cloreto de sodio.

12. Meio para as provas de utilizaçăo dos açúcares sacarose, manitol, inositol, salicina e arabinose Preparava-se o caldo-base vermelho de fenol (Difco $0092)$ de acordo com as recomendaçós do fabricante. Assim, 
apos a dissoluçăo dos ingredientes por aquecimento, a meio era distribuido em volumes de $100 \mathrm{~mL}$, em frascos de Erlenmeyer, os quais eram esterilizados a $1210 \mathrm{C}$ durante 15 minutos. Apos a esterilizaça, os frascos eram esfriados e em cada um eram adicionados, assepticamente, $10 \mathrm{~mL}$ de soluçă a $5 \%$ do açúcar correspondente, esterilizado por filtraça em membrana filtrante (Millipore). Em seguida, em capela de fluxo laminar, cada meio era distribuldo em volumes de $\Xi \mathrm{mL}$ em tubos $12 \times 120 \mathrm{~mm}$ esterilizados e mantido sob refrigeraçăo a cerca de $4 \%$.

13. Meio para a prova da produço de gás a partir da glicose

o caldo-base vermelho de fenol (Difco 0092) era adicionado de glicose de modo a se obter uma concentração final deste açucar de $0,7 \%$. Apos a dissoluçăo dos ingredientes e o ajuste do $\mathrm{pH}$ a 7,4, o meio era adicionado de $0,7 \%$ de glicose e distribuido, em volumes de $3 \mathrm{~mL}$, em tubos $12 \times 120 \mathrm{~mm}$, contendo um tubo de Duhran invertido em cada um. Em seguida, o meio era esterilizado em autoclave a $1210 \mathrm{C}$ durante 10 minutos. Apos a esterilizaça, os tubos eram esfriados e mantidos em temperatura ambiente.

\section{Meio Clark-Lubs para a prova de Voges-Proskauer (Meio} MR-UF-Difco 0016 )

Esse meio de cultura era preparado e esterilizado conforme as instrucbes do fabricante. Assim, o meio era dissolvido e distribuido, em volumes de $4 \mathrm{~mL}$ em tubos $12 \times 120$ 
$\mathrm{mm}$. Em seguida, o meio era esterilizado em autoclave a 1210C, durante 15 minutos. Apos a esterilizacao, o meio era resfriado e mantido sob refrigeraça a, aproximadamente, $40 \mathrm{C}$.

15. Agar bile-esculina (MaC FADDIN, 1976)

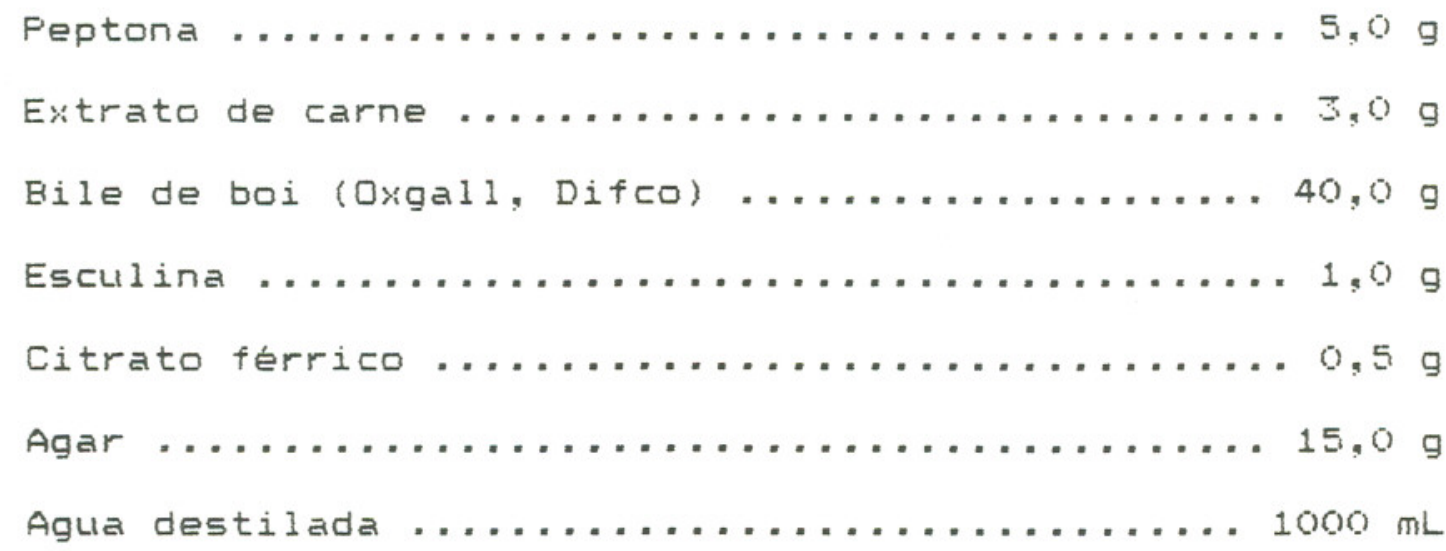

Os ingredientes eram dissolvidos por aquecimento, - meio, apos ter seu pH ajustado a $6,6 \pm 0,2$, era distribuido em volumes de $\Xi \mathrm{mL}$, em tubos $12 \times 120 \mathrm{~mm}$ e esterilizado em autoclave a $1210 \mathrm{C}$ durante 15 minutos. Apos a esterilizaçă, os tubos eram mantidos em posiça inclinada, em temperatura ambiente até a sua solidificaçă e, em seguida, mantidos sob refrigeração a cerca de $4 \circ \mathrm{C}$.

16. Meio-base de Falcow para as provas de utilizaçăo dos amino-acidos arginina, lisina e ornitina (Difco 0872)

0 meio era preparado conforme instruçoses do
fabricante, tendo sido adicionados 5 g de L-arginina, L-


lisina ou L-ornitina para cada litro de meio. Faralelamente, foi preparada base sem a adiça de amino-acido, como controle. O pH do meio era ajustado a $6,8 \pm 0,2$. A cada tubo de $12 \times 120 \mathrm{~mm}$, contendo $4 \mathrm{~mL}$ de base de Falkow, contendo ou năo amino-acido, foi adicionada vaselina liquida previamente a autoclavaçă, feita a $1210 \mathrm{C}$ durante 15 minutos.

\section{Agar sangue de carneiro}

Foi preparado, adicionando-se $5 \mathrm{~mL}$ de sangue esteril desfibrinado de carneiro a $95 \mathrm{~mL}$ de agar base de Colúmbia (Difco 0792), previamente preparada e esterilizada seguindo instruçâs do fabricante e esfriada a 450C. Apos homogeinizaça, o agar sangue foi distribuldo em placas de Petri estereis, em volumes de 10 a, no maximo, $15 \mathrm{~mL}$, de maneira a formar uma camada bem fina em cada placa.

18. Lugol (ICMSF, 1978)

Iodo $\ldots \ldots \ldots \ldots \ldots \ldots \ldots \ldots \ldots \ldots \ldots \ldots \ldots$

Iodeto de potássio ..................... 2 g

Agua destilada ..................... $300 \mathrm{~mL}$

19. Tiras para oxidase (Difco 007 )

20. Reagente para a prova da catalase (ICMSF, 1978)

Agua oxigenada a $\$ \%$ 
21. Reagentes A e B para nitritos (ICMSF, 1978)

\subsection{Reagente $A$}

Acido sulfanilico ................... 1,0 g

Acido acetico $5 \mathrm{~N} . \ldots \ldots \ldots . . . \ldots \ldots \ldots . . .125 \mathrm{~mL}$ Dissolvia-se o acido sulfanilico no acido acetico e filtrava-se.

\subsection{Reagente B}

Alfa-naftilamina .................. 1,0 g Acido acetico $5 \mathrm{~N} \ldots \ldots \ldots \ldots \ldots . . . . . . .200 \mathrm{~mL}$

22. Reagente de Ehrlich para indol (Mac Faddin, 1976)

p-dimetilaminobenzaldeido ............... 2,0 g Alcool absoluto ........................ $190 \mathrm{~mL}$ Acido cloridrico concentrado................40 40 Dissolvia-se o aldeldo no álcool e adicionava-se o acido.

23. Reagentes A e B para UP (AFHA, 1992)

\subsection{Reagente A}

Alfa-naftol .....................5,0 g Alcool absoluto ..................... $100 \mathrm{~mL}$ 


\subsection{Reagente B}

Hidroxido de potassio .............. 40,0 g Agua destilada ................... $100 \mathrm{~mL}$

24. Corante de Ryu para flagelos (HEIMBROOK et al., 1989)

- Solucão I (mordente)

Solução aquosa de fenol a $5 \% \ldots . \ldots \ldots \ldots \ldots . . .10 \mathrm{~mL}$ Acido tanico ........................ 2, Solução sat. de 12-hidrato de sulfato potassico de aluminio ............ $10 \mathrm{~mL}$

- Solucão II (corante) - soluçăo saturada de cristal violeta

Cristal violeta ...................... 12 g

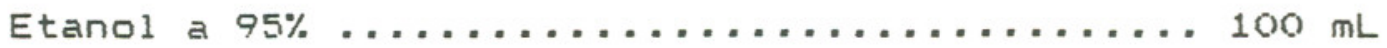

- Mistura final

1 parte de solucão II : 10 partes de soluça I 